\title{
N-Heterocyclic Carbene-Stabilized Germanium and Tin Analogues of Heavier Nitriles: Synthesis, Reactivity, and Catalytic Application
}

Vitaly Nesterov ${ }^{\dagger}$ Ramona Baierl,${ }^{\dagger}$ Franziska Hanusch, ${ }^{\dagger}$ Arturo Espinosa Ferao, ${ }^{\S}$ and Shigeyoshi Inoue ${ }^{*, \dagger}$

Affiliations: 'Department of Chemistry, WACKER-Institute of Silicon Chemistry and Catalysis Research Center, Technische Universität München, Lichtenbergstraße 4, 85748 Garching bei München, Germany

${ }^{\S}$ Departamento de Química Orgánica, Facultad de Química, Universidad de Murcia, Campus de Espinardo, 30100 Murcia, Spain

\section{Supporting Information}

\section{Contents}

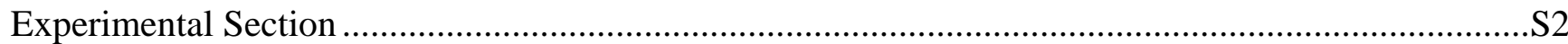

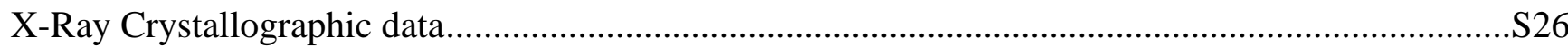

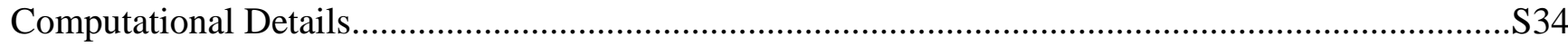

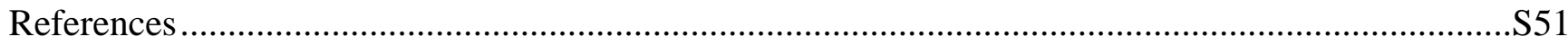




\section{Experimental Section}

\section{General Considerations}

All experiments and manipulations were carried out under dry oxygen-free argon atmosphere using standard Schlenk techniques or in a glovebox. All glass junctions were coated with PTFE-based grease Merkel Triboflon III. All the solvents were dried and freshly distilled under Ar atmosphere prior to use using standard techniques. The ${ }^{1} \mathrm{H},{ }^{13} \mathrm{C}\left\{{ }^{1} \mathrm{H}\right\},{ }^{31} \mathrm{P}\left\{{ }^{1} \mathrm{H}\right\},{ }^{11} \mathrm{~B}$, and ${ }^{119} \mathrm{Sn}\left\{{ }^{1} \mathrm{H}\right\}$ NMR spectra were recorded on Bruker $400 \mathrm{MHz}$ spectrometer. Chemical shifts are referenced to (residual) solvent signals $\left({ }^{1} \mathrm{H}\right.$ and ${ }^{13} \mathrm{C}\left\{{ }^{1} \mathrm{H}\right\}$ NMR). Abbreviations: $\mathrm{s}=$ singlet, $\mathrm{br}=$ broadened, $\mathrm{d}=$ doublet, $\mathrm{t}=$ triplet, $\mathrm{m}=$ multiplet. ATRFT-IR spectra were recorded on a Bruker Alpha FT-IR spectrometer (diamond ATR, located inside an argon-filled glovebox) in a range of $400-4000 \mathrm{~cm}^{-1}$. UV-Vis spectra were taken on an Agilent Cary 60 spectrophotometer (Unisoku Scientific Instruments Co.). Elemental analyses (EA) were conducted with a EURO EA (HEKA tech) instrument equipped with a CHNS combustion analyzer.

\section{Synthetic Procedures}

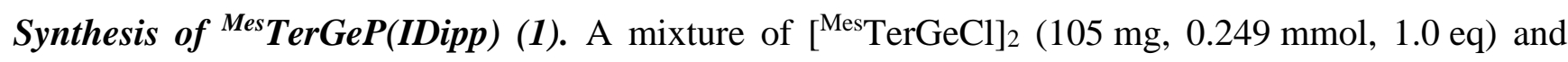
(IDipp)PSiMe 3 (123 mg, $0.249 \mathrm{mmol}, 1.0 \mathrm{eq}$ ) was dissolved in toluene (5 mL). The obtained solution was heated at $75{ }^{\circ} \mathrm{C}$ for two hours. The solvent was removed and the obtained solid recrystallized from $n$-pentane at $-30{ }^{\circ} \mathrm{C}$ to give 1 as orange crystals (164.5 mg, $0.204 \mathrm{mmol}, 82 \%$ ).

${ }^{1} \mathrm{H}$ NMR $\left(400 \mathrm{MHz}, \mathrm{C}_{6} \mathrm{D}_{6}\right) \delta[\mathrm{ppm}]=7.24\left(\mathrm{t},{ }^{3} J_{\mathrm{H}, \mathrm{H}}=7.7 \mathrm{~Hz}, 1 \mathrm{H}, \mathrm{CH}, p-\mathrm{C}_{6} \mathrm{H}_{3},{ }^{\text {Mes Ter }}\right), 7.18\left(\mathrm{t},{ }^{3} J_{\mathrm{H}, \mathrm{H}}=\right.$ $\left.7.7 \mathrm{~Hz}, 2 \mathrm{H}, \mathrm{CH}, p-\mathrm{C}_{6} \mathrm{H}_{3}, 2 \mathrm{Dipp}\right), 7.01\left(\mathrm{~d},{ }^{3} \mathrm{~J}_{\mathrm{H}, \mathrm{H}}=7.8 \mathrm{~Hz}, 4 \mathrm{H}, \mathrm{CH}, m-\mathrm{C}_{6} \mathrm{H}_{3}, 2 \mathrm{Dipp}\right), 6.86\left(\mathrm{~d},{ }^{3} J_{\mathrm{H}, \mathrm{H}}=7.5\right.$ $\mathrm{Hz}, 2 \mathrm{H}, \mathrm{CH}, m-\mathrm{C}_{6} \mathrm{H}_{3}$, ${ }^{\mathrm{Mes}} \mathrm{Ter}$ ), 6.65 (s, $4 \mathrm{H}, \mathrm{CH}, m-\mathrm{Mes}$ ), 6.33 (s, 2H, $2 \mathrm{HCN}$ ), 2.65 (hept, ${ }^{3} J_{\mathrm{H}, \mathrm{H}}=6.8 \mathrm{~Hz}$, $4 \mathrm{H}, \mathrm{CH}, i \mathrm{Pr}$ ), 2.30 (s, 6H, $p-\mathrm{CH}_{3}, \mathrm{Mes}$ ), 2.27 (s, 12H, o- $\left.\mathrm{CH}_{3}, \mathrm{Mes}\right), 1.04$ (d, ${ }^{3} \mathrm{~J}_{\mathrm{H}, \mathrm{H}}=6.8 \mathrm{~Hz}, 12 \mathrm{H}, \mathrm{CH}_{3}$, $i \operatorname{Pr}), 1.01\left(\mathrm{~d},{ }^{3} J_{\mathrm{H}, \mathrm{H}}=6.8 \mathrm{~Hz}, 12 \mathrm{H}, \mathrm{CH}_{3}, i \operatorname{Pr}\right) .{ }^{13} \mathrm{C} \mathrm{NMR}\left(100.62 \mathrm{MHz}, \mathrm{C}_{6} \mathrm{D}_{6}\right) \delta[\mathrm{ppm}]=176.06(d, \mathrm{CP}$, $\left.{ }^{1} J_{\mathrm{C}, \mathrm{P}}=129.1 \mathrm{~Hz}\right), 165.66,165.44,145.71,145.17,140.25,136.10,134.89,134.62,130.57\left(\mathrm{~s}, p-\mathrm{C}_{6} \mathrm{H}_{3}\right.$,

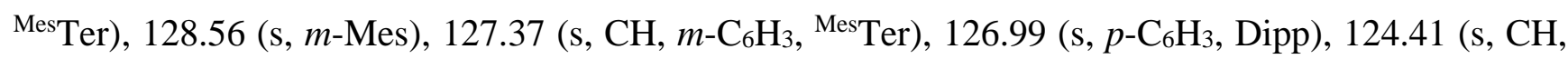
$\left.m-\mathrm{C}_{6} \mathrm{H}_{3}, 2 \mathrm{Dipp}\right), 122.79$ (s, 2H, 2HCN), 29.08 (s, CH, $i \operatorname{Pr}$ ), 25.24 (s, CH, $i \operatorname{Pr}$ ), 22.84 (s, $\mathrm{CH}_{3}, i \operatorname{Pr}$ ), 22.31 (o- $\left.\mathrm{CH}_{3}, \mathrm{Mes}\right), 22.26\left(o-\mathrm{CH}_{3}, \mathrm{Mes}\right), 21.57$ (s, $\left.p-\mathrm{CH}_{3}, \mathrm{Mes}\right) .{ }^{31} \mathrm{P}\left\{{ }^{1} \mathrm{H}\right\} \mathrm{NMR}\left(162 \mathrm{MHz}, \mathrm{C}_{6} \mathrm{D}_{6}\right) \delta[\mathrm{ppm}]=$ 216.8 (s). FT-IR (neat) $\tilde{v}\left[\mathrm{~cm}^{-1}\right]=2958(\mathrm{~m}), 1441(\mathrm{~m}), 1324$ (s), 842 (m), 797 (m), 737 (m), 702 (m), 475 (m). UV-Vis (n-pentane) $\lambda_{\max }$ [nm] (ع): 258 (20980), 363 (8140), 442 (6800). Anal. calc. for $\mathrm{C}_{51} \mathrm{H}_{61} \mathrm{GeN}_{2} \mathrm{P}: \mathrm{C} 76.03 \%$, H $7.63 \%$, N $3.48 \%$, found: C $76.08 \%, \mathrm{H} 7.81 \%, \mathrm{~N} 3.55 \%$. 


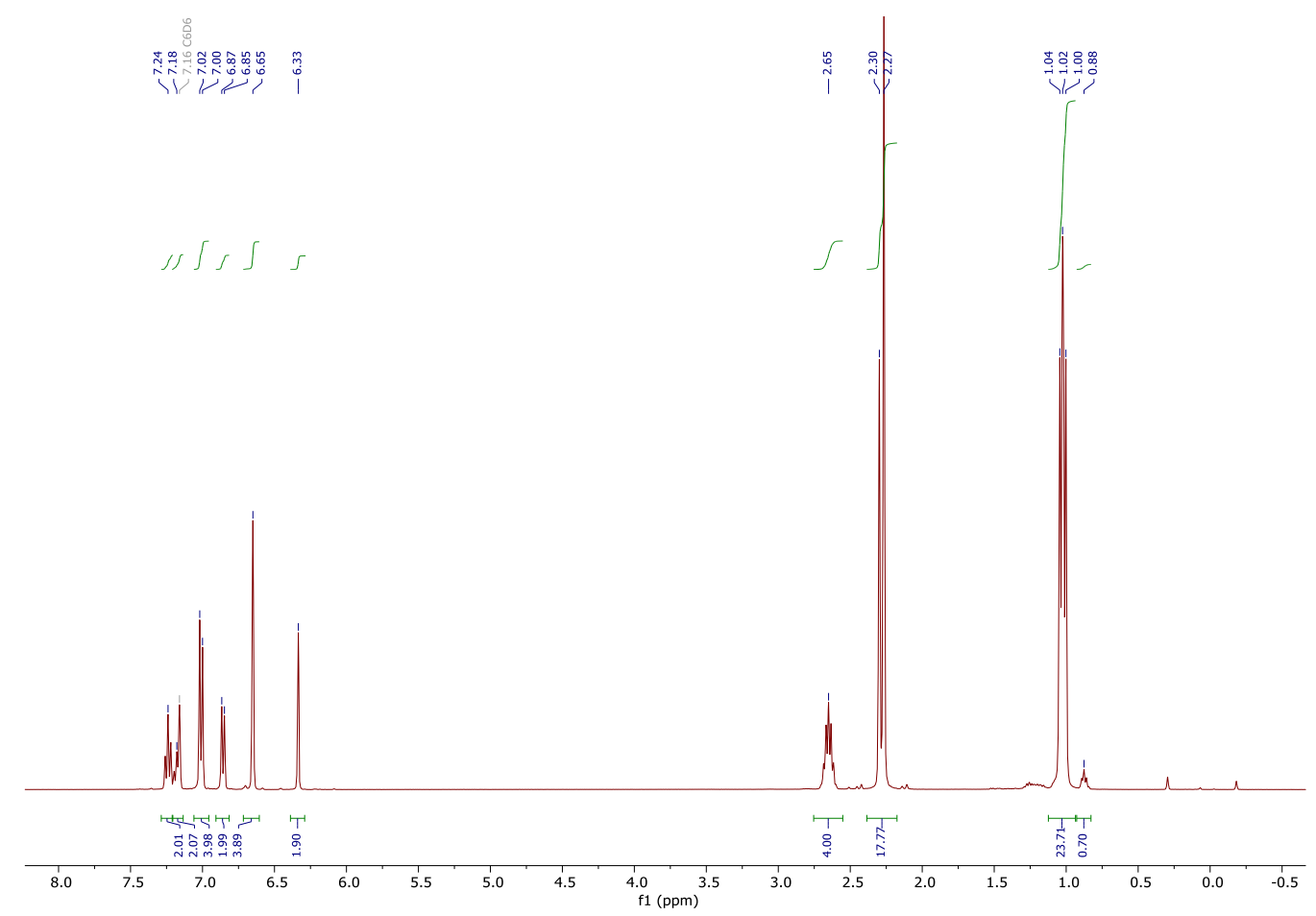

Figure S1. ${ }^{1} \mathrm{H}$ NMR spectrum of germylene-phosphinidene $1\left(\mathrm{C}_{6} \mathrm{D}_{6}\right)$.

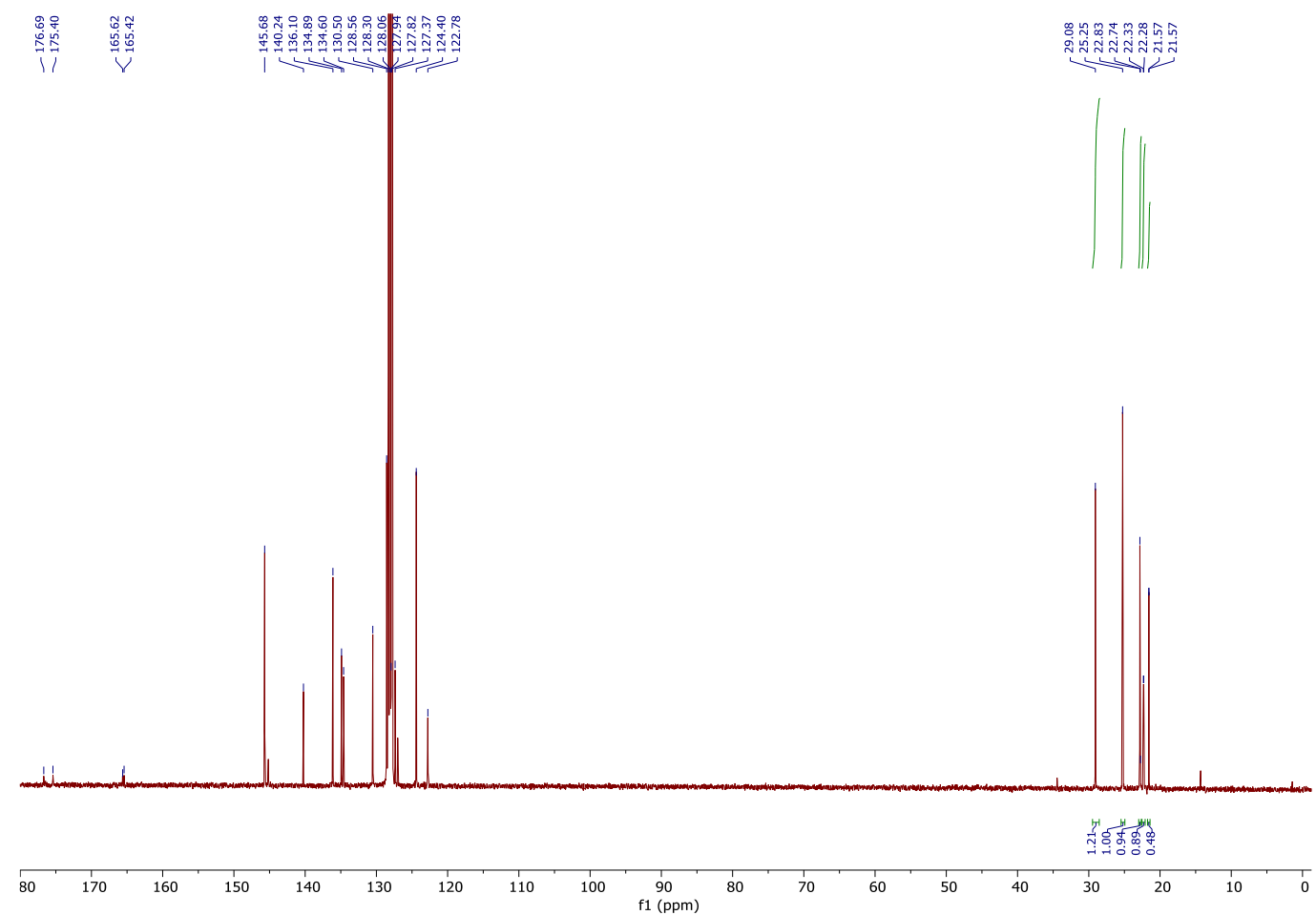

Figure S2. ${ }^{13} \mathrm{C}$ NMR spectrum of germylene-phosphinidene $\mathbf{1}\left(\mathrm{C}_{6} \mathrm{D}_{6}\right)$. 


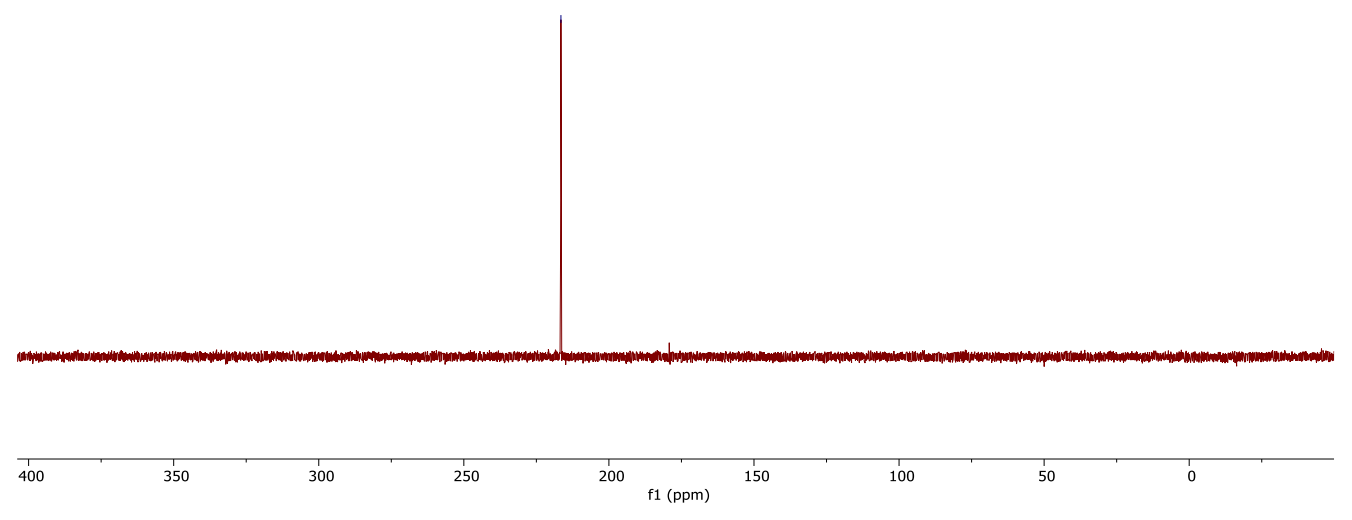

Figure S3. ${ }^{31} \mathrm{P}\left\{{ }^{1} \mathrm{H}\right\}$ NMR spectrum of germylene-phosphinidene $\mathbf{1}\left(\mathrm{C}_{6} \mathrm{D}_{6}\right)$.

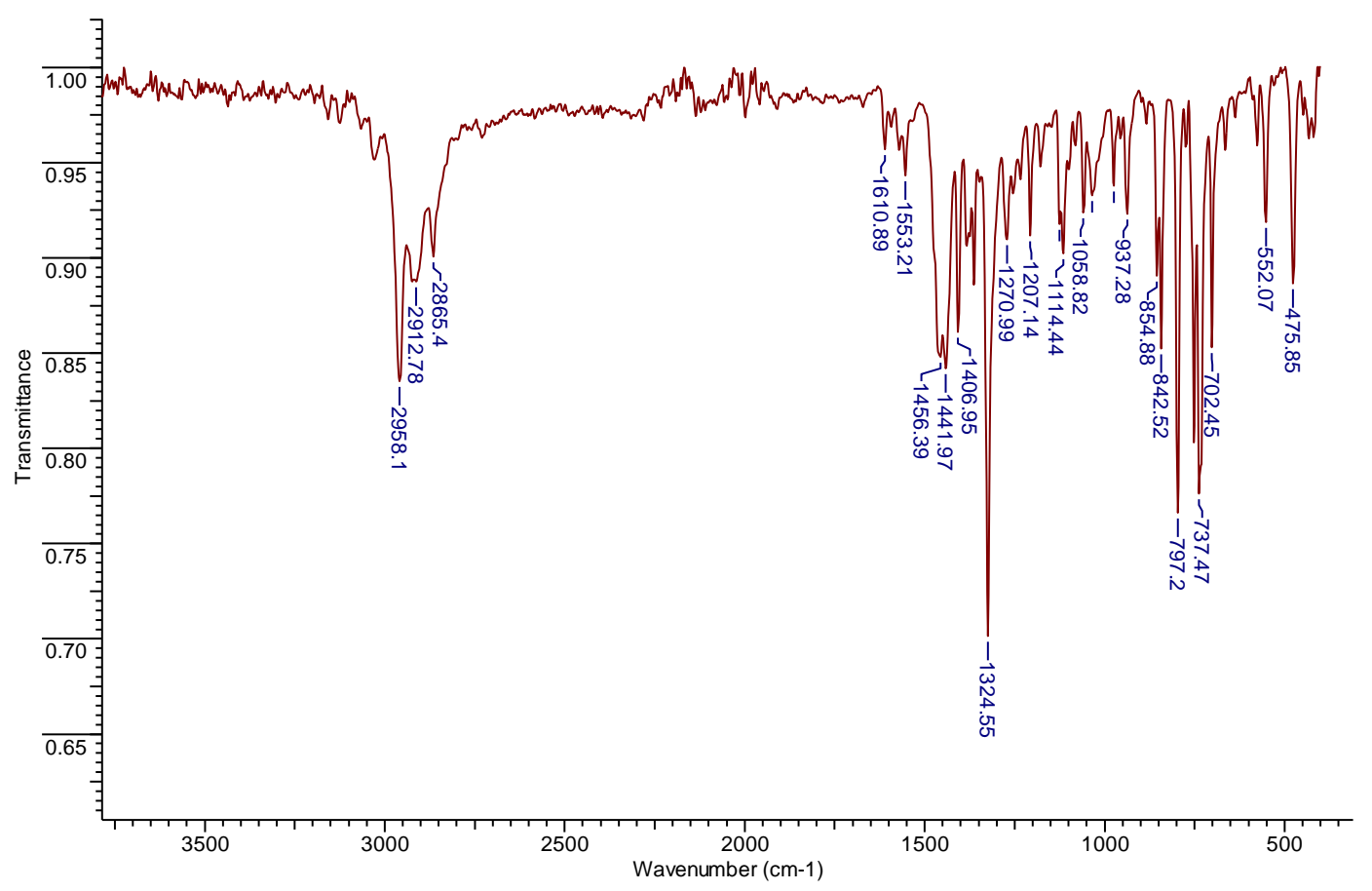

Figure S4. FT-IR spectrum of germylene-phosphinidene complex 1. 


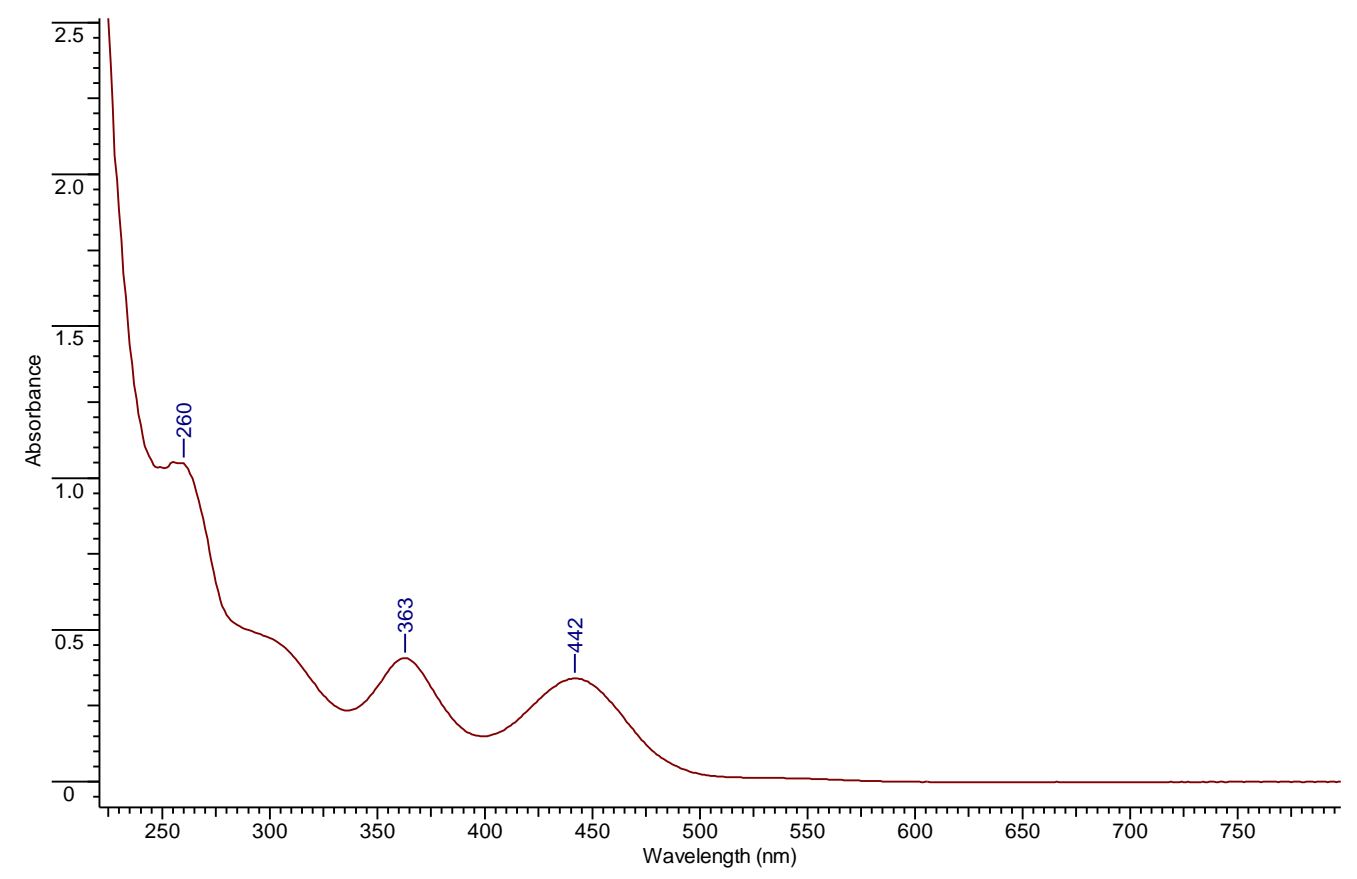

Figure S5. UV-Vis spectrum of germylene-phosphinidene complex 1 ( $n$-pentane, $5.0 \times 10^{-5} \mathrm{M}$ ).

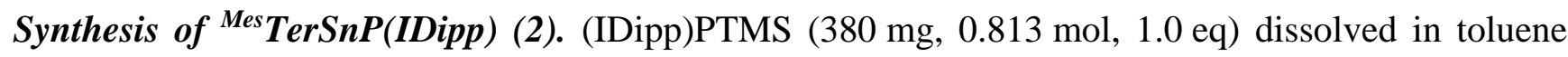
$(6 \mathrm{~mL})$ was added dropwise to a solution of ${ }^{\mathrm{Mes}} \mathrm{TerSnCl}(400 \mathrm{mg}, 0.812 \mathrm{mmol}, 1.0 \mathrm{eq})$ in toluene $(16 \mathrm{~mL})$ to give a dark red solution which was heated at $75{ }^{\circ} \mathrm{C}$ for 3 days. The solvent was removed in vacuo and the solid residue was extracted with $n$-pentane $(60 \mathrm{~mL})$. The filtrate was concentrated and stored in the freezer for crystallization. The product was obtained as dark red needles (495 mg, $0.581 \mathrm{mmol}, 72 \%)$.

${ }^{1} \mathrm{H}$ NMR $\left(400 \mathrm{MHz}, \mathrm{C}_{6} \mathrm{D}_{6}\right) \delta[\mathrm{ppm}]=7.25\left(\mathrm{t},{ }^{3} J_{\mathrm{H}, \mathrm{H}}=7.5 \mathrm{~Hz}, 1 \mathrm{H}, \mathrm{CH}, p-\mathrm{C}_{6} \mathrm{H}_{3}\right.$, ${ }^{\text {Mes }}$ Ter $), 7.19\left(\mathrm{t},{ }^{3} J_{\mathrm{H}, \mathrm{H}}=\right.$ $7.7 \mathrm{~Hz}, 2 \mathrm{H}, \mathrm{CH}, p-\mathrm{C}_{6} \mathrm{H}_{3}$, Dipp), $7.05\left(\mathrm{~d},{ }^{3} \mathrm{~J}_{\mathrm{H}, \mathrm{H}}=7.7 \mathrm{~Hz}, 4 \mathrm{H}, \mathrm{CH}, m-\mathrm{C}_{6} \mathrm{H}_{3}, \mathrm{Dipp}\right), 6.95\left(\mathrm{~d},{ }^{3} J_{\mathrm{H}, \mathrm{H}}=7.5 \mathrm{~Hz}\right.$, $2 \mathrm{H}, \mathrm{CH}, m-\mathrm{C}_{6} \mathrm{H}_{3},{ }^{\mathrm{Mes}} \mathrm{Ter}$ ), 6.73 (s, 4H, CH, $m$-Mes), 6.32 (s, 2H, N-CH), 2.65 (hept, ${ }^{3} J_{\mathrm{H}, \mathrm{H}}=6.8 \mathrm{~Hz}, 4 \mathrm{H}$, $\mathrm{CH}, i \mathrm{Pr}$ ), 2.31 (s, 12H, o- $\mathrm{CH}_{3}$, ${ }^{\text {Mes Ter) }}, 2.27$ (s, 6H, $\left.p-\mathrm{CH}_{3},{ }^{\text {Mes }} \mathrm{Ter}\right), 1.06\left(\mathrm{~d},{ }^{3} \mathrm{~J}_{\mathrm{H}, \mathrm{H}}=6.8 \mathrm{~Hz}, 12 \mathrm{H}, \mathrm{CH}_{3}\right.$, $i \operatorname{Pr}), 1.04\left(\mathrm{~d},{ }^{3} J_{\mathrm{H}, \mathrm{H}}=6.9 \mathrm{~Hz}, 12 \mathrm{H}, \mathrm{CH}_{3}, i \mathrm{Pr}\right) .{ }^{13} \mathrm{C} \mathrm{NMR}\left(100.62 \mathrm{MHz}, \mathrm{C}_{6} \mathrm{D}_{6}\right) \delta[\mathrm{ppm}]=177.62,176.78$, 176.57, 176.28, 147.53, 146.08, 139.68, 136.31, 135.45, 135.27, 130.58 (s, $p$ - $\mathrm{C}_{6} \mathrm{H}_{3}$, Mes Ter), 128.63 (s, $m$-Mes), 127.75 (s, CH, $m$ - $\mathrm{C}_{6} \mathrm{H}_{3}$, ${ }^{\text {Mes }}$ Ter), 127.26 (s, $p-\mathrm{C}_{6} \mathrm{H}_{3}, \mathrm{Dipp}$ ), 124.95 (s, CH, $m$ - $\mathrm{C}_{6} \mathrm{H}_{3}$, Dipp), 121.92 (s, 2H, 2HCN), 28.98 (s, CH, $i \operatorname{Pr}$ ), 24.99 (s, CH, $i \operatorname{Pr}$ ), 23.34 (s, $\mathrm{CH}_{3}, i \operatorname{Pr}$ ), 22.52 (o- $\mathrm{CH}_{3}, \mathrm{Mes}$ ), 22.47 (o- $\left.\mathrm{CH}_{3}, \mathrm{Mes}\right), 21.50$ (s, $\left.p-\mathrm{CH}_{3}, \mathrm{Mes}\right) .{ }^{31} \mathrm{P}\left\{{ }^{1} \mathrm{H}\right\} \mathrm{NMR}\left(122 \mathrm{MHz}, \mathrm{C}_{6} \mathrm{D}_{6}\right) \delta[\mathrm{ppm}]=176.37$ (ssat, $\left.{ }^{1} J_{\mathrm{Sn}, \mathrm{P}}=1648.8 \mathrm{~Hz}, 1569.8 \mathrm{~Hz}\right) .{ }^{119} \mathrm{Sn}\left\{{ }^{1} \mathrm{H}\right\} \mathrm{NMR}\left(112 \mathrm{MHz}, \mathrm{C}_{6} \mathrm{D}_{6}\right) \delta[\mathrm{ppm}]=1689.76\left(\mathrm{~d},{ }^{1} J_{\mathrm{Sn}, \mathrm{P}}=1648.2\right.$ Hz). FT-IR (neat) $\tilde{v}\left[\mathrm{~cm}^{-1}\right]=2958(\mathrm{~m}), 1446(\mathrm{~m}), 1308$ (s), $1110(\mathrm{~m}), 844$ (m), 799 (m), 731 (m), 554 (m), $479(\mathrm{~m})$. UV-Vis (n-pentane) $\lambda_{\max }[\mathrm{nm}]\left(\varepsilon\left[\mathrm{L} \mathrm{mol}^{-1} \mathrm{~cm}^{-1}\right]\right): 272$ (15740), 314 (13600), 481 (5920). Anal. calc. for $\mathrm{C}_{51} \mathrm{H}_{61} \mathrm{~N}_{2} \mathrm{PSn}$ : C $71.92 \%, \mathrm{H} 7.22 \%$, N $3.29 \%$, found: C $71.76 \%$, H $7.25 \%$, N $3.25 \%$. 


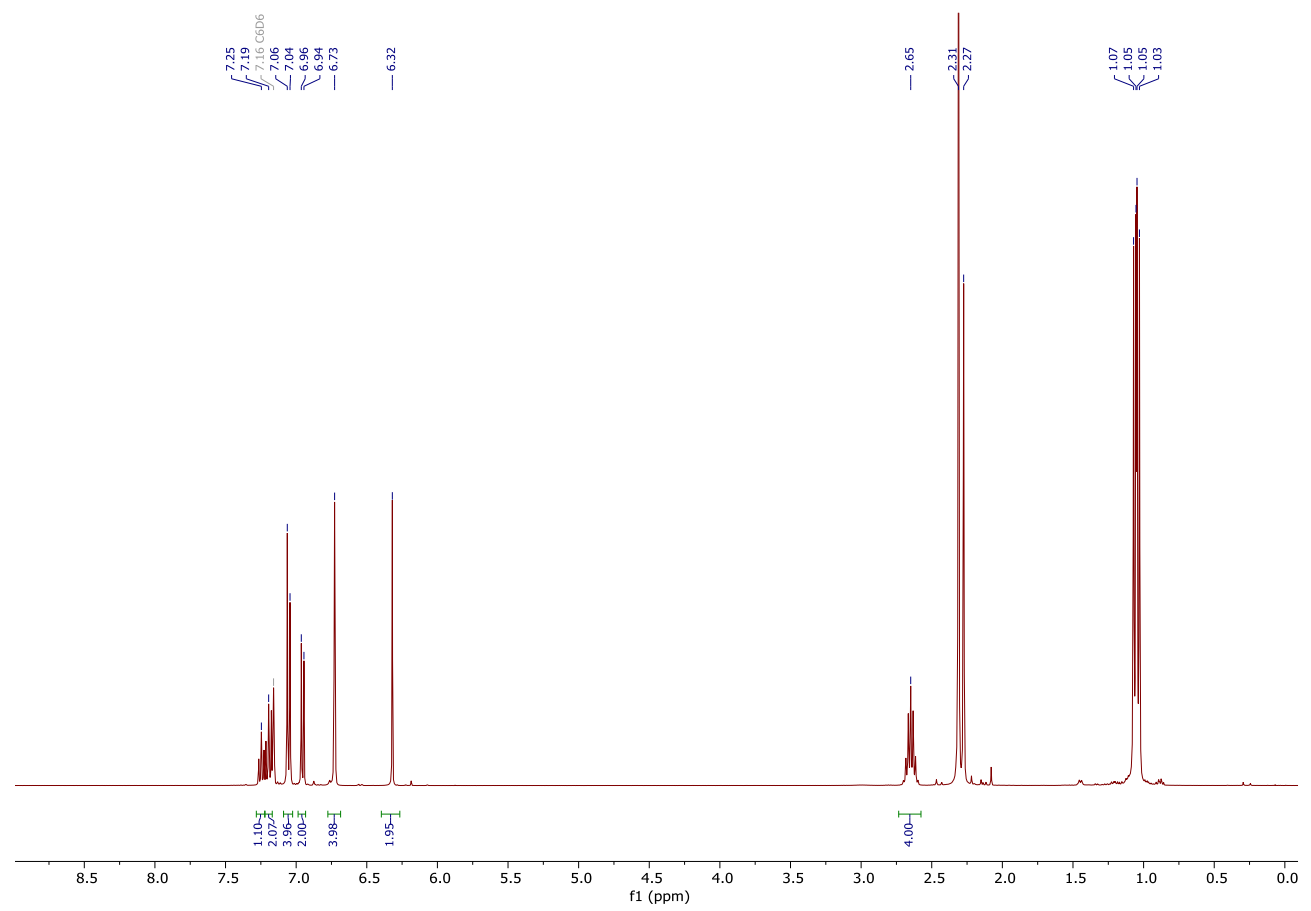

Figure S6. ${ }^{1} \mathrm{H}$ NMR spectrum of stannylene-phosphinidene $2\left(\mathrm{C}_{6} \mathrm{D}_{6}\right)$.

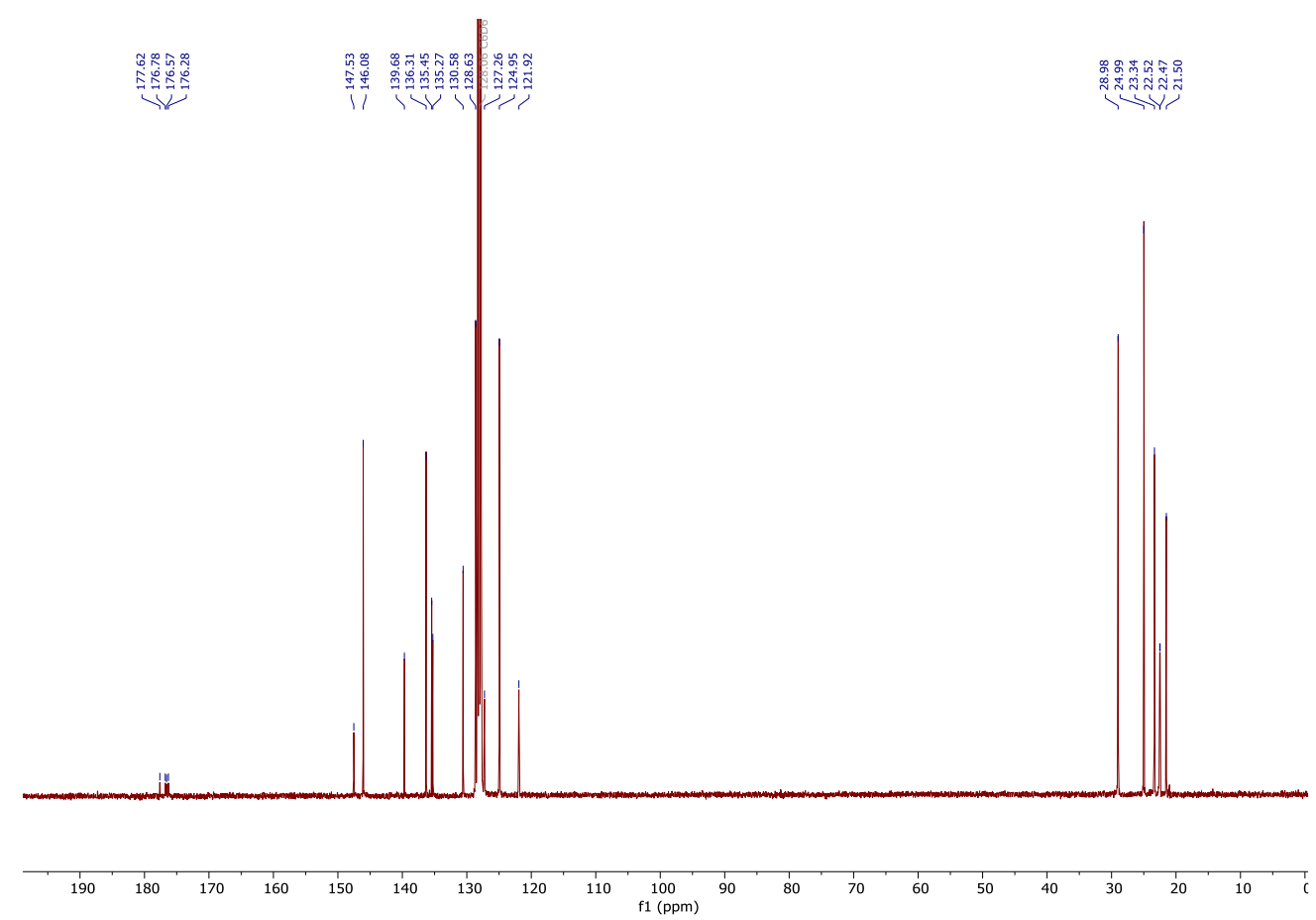

Figure S7. ${ }^{13} \mathrm{C}$ NMR spectrum of stannylene-phosphinidene $2\left(\mathrm{C}_{6} \mathrm{D}_{6}\right)$. 


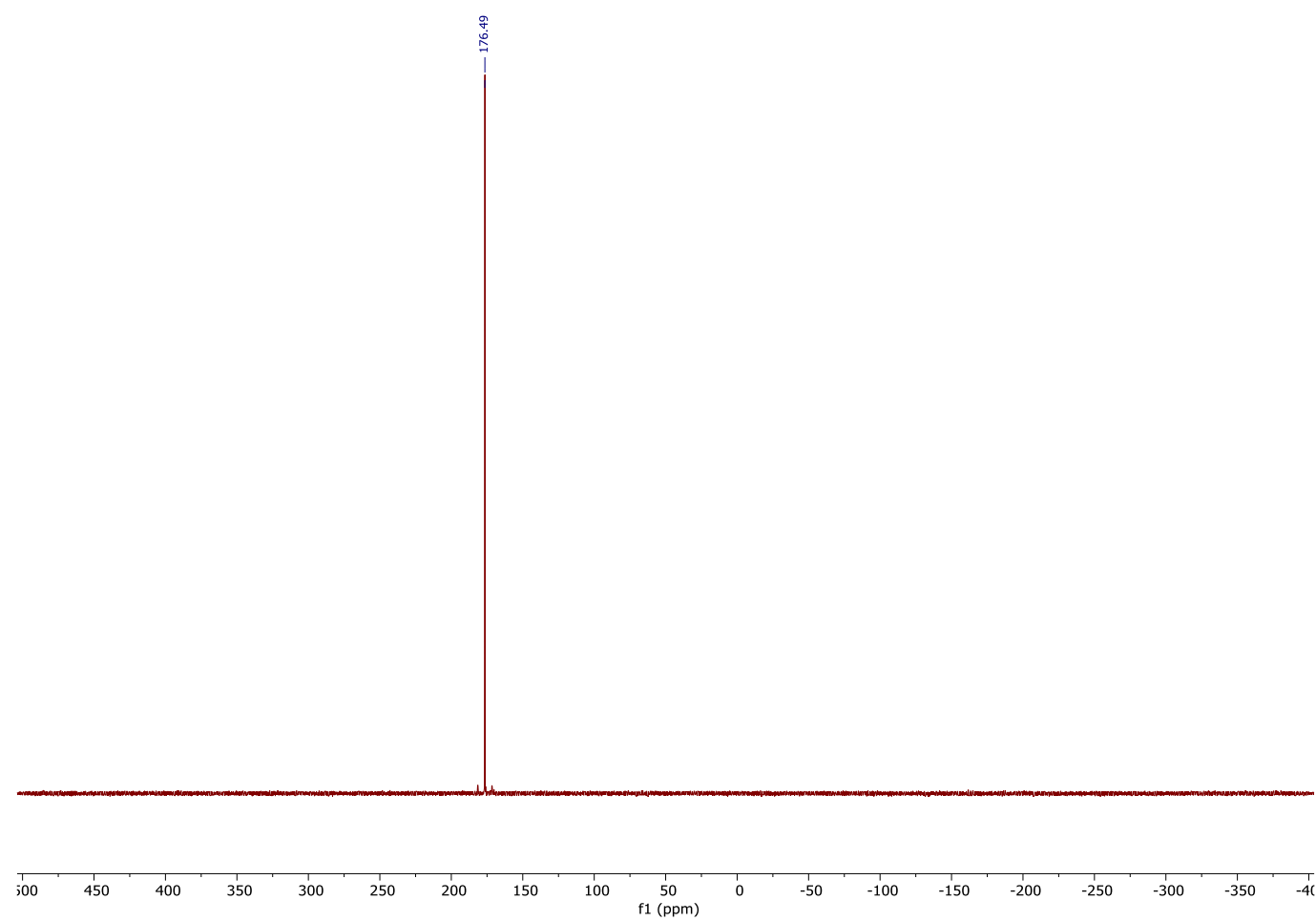

Figure S8. ${ }^{31} \mathrm{P}$ NMR spectrum of stannylene-phosphinidene $2\left(\mathrm{C}_{6} \mathrm{D}_{6}\right)$.

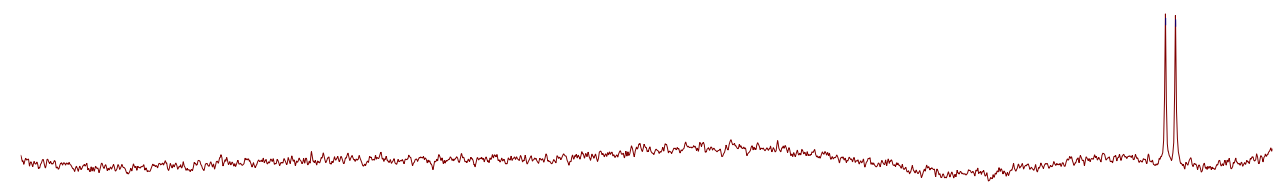

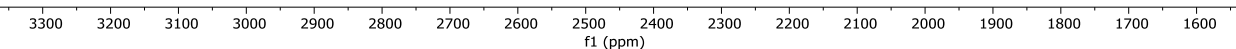

Figure S9. ${ }^{119} \mathrm{Sn}$ NMR spectrum of stannylene-phosphinidene $2\left(\mathrm{C}_{6} \mathrm{D}_{6}\right)$. 


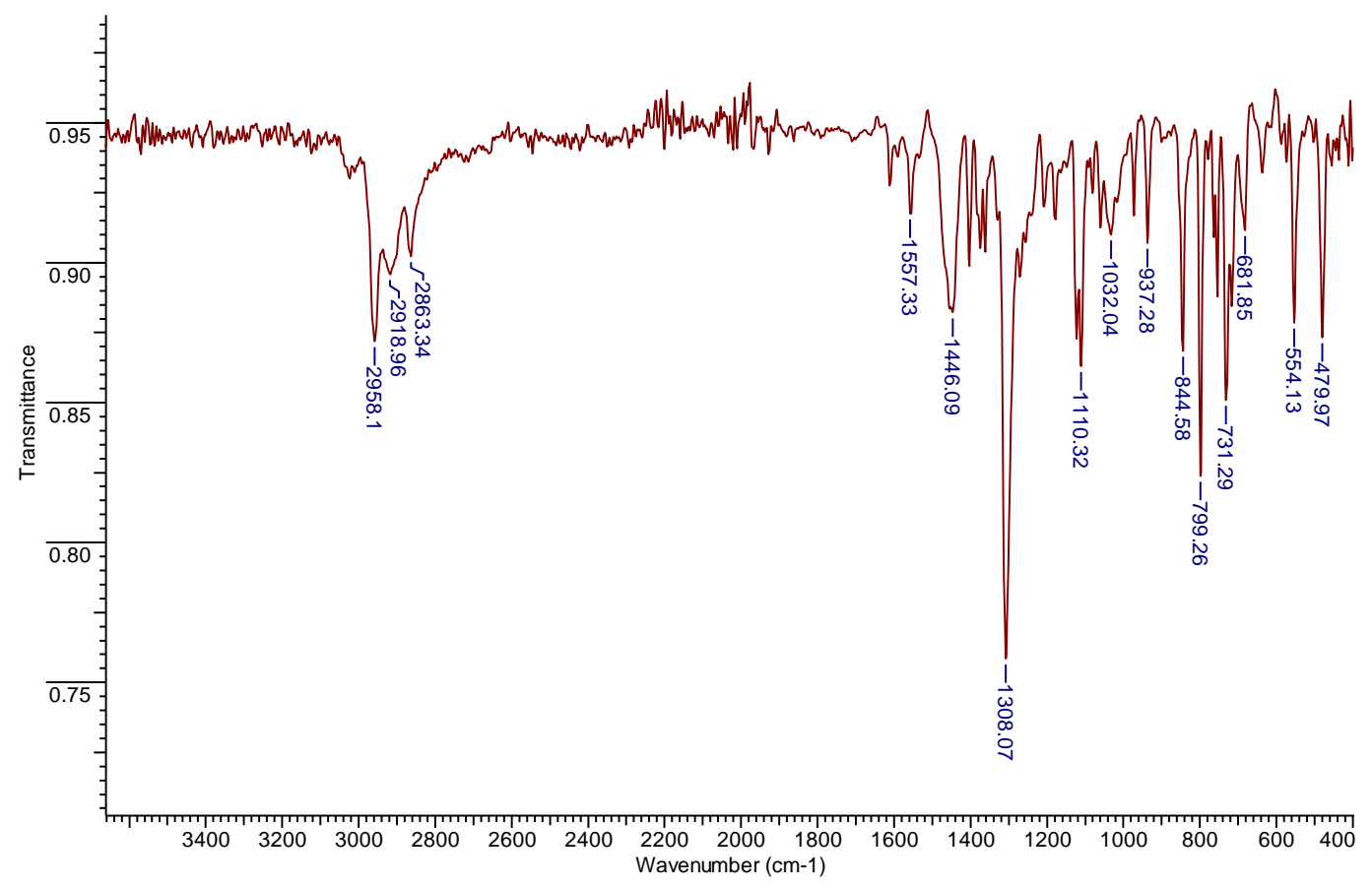

Figure S10. FT-IR spectrum of stannylene-phosphinidene complex 2.

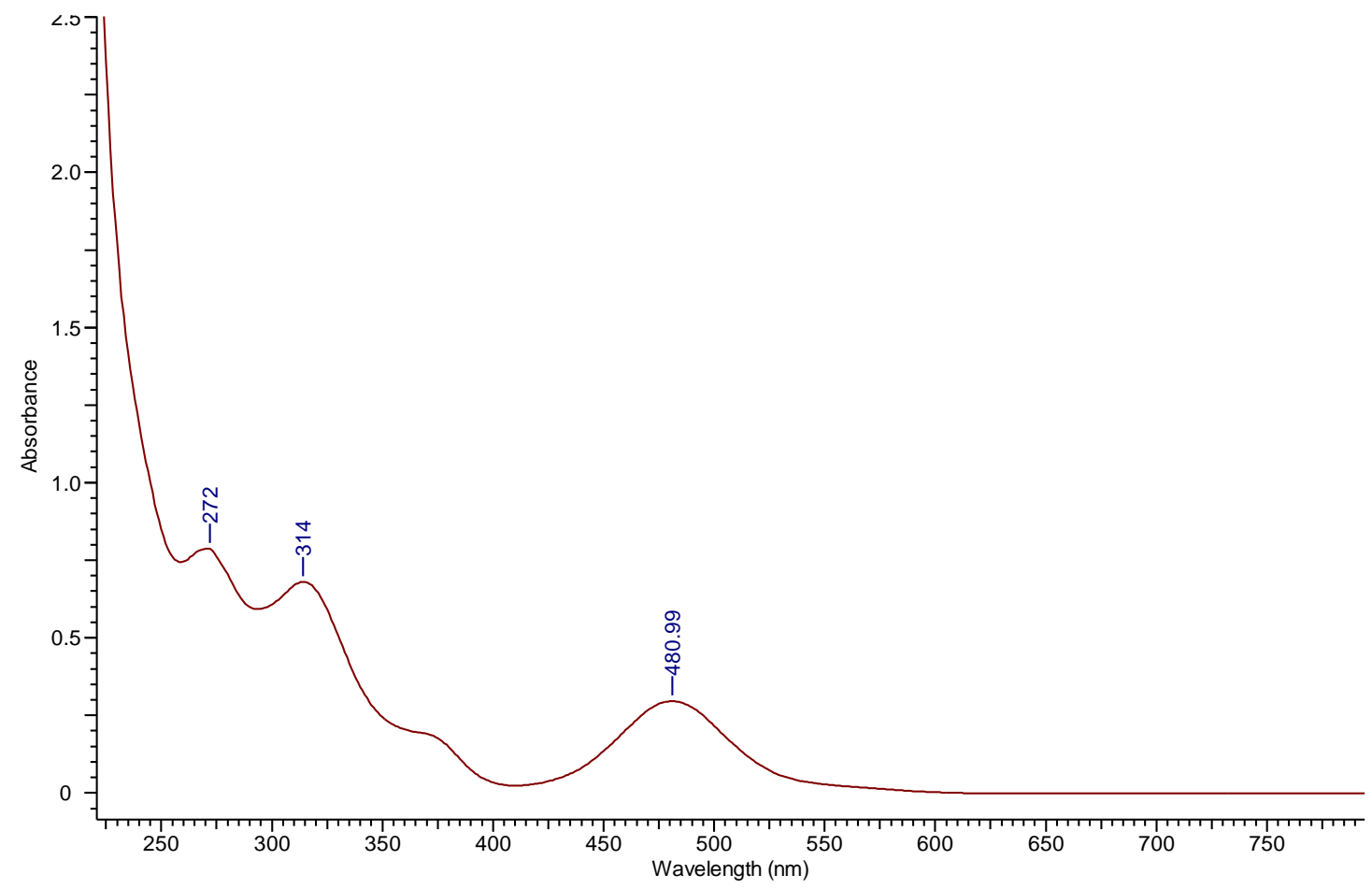

Figure S11. UV-Vis spectrum of stannylene-phosphinidene complex 2 (n-pentane, $\left.5.0 \times 10^{-5} \mathrm{M}\right)$. 
General procedure for the synthesis of heterocycles 3 and 4. Diphenylketene (1.7 eq, $70 \%$ excess) was added to a stirred solution of $1(33.5 \mathrm{mg}, 0.0416 \mathrm{mmol})$ or $2(46 \mathrm{mg}, 0.054 \mathrm{mmol})$ in toluene $(1.5 \mathrm{~mL})$ at room temperature. The reaction mixture was intensively stirred for $12 \mathrm{~h}$. The solvent was removed in vacuo, the residue was washed with pentane $(3 \times 1 \mathrm{~mL})$ and dried in vacuo. Products 3 and 4 were obtained as dark yellow solids. Both are sparingly soluble in $\mathrm{C}_{6} \mathrm{D}_{6}$, soluble in THF- $d_{8}$ (low stability), and insoluble in $\mathrm{CDCl}_{3}$.

(IDipp)PGe( ${ }^{\text {Mes }}$ Ter)OC(CPh$)$ (3). Yield: $44 \mathrm{mg}(0.044 \mathrm{mmol}, 93 \%)$.

${ }^{1} \mathrm{H}$ NMR (400 MHz, C6 $\left.\mathrm{D}_{6}\right) \delta[\mathrm{ppm}]=7.34$ (br, 1H, Ar), 7.24-6.81 (m, 21H, Ar), 6.41 (br, 1H, Ar), 6.22 (s, 2H, 2CHN), 3.28 (br, 1CH, $i \operatorname{Pr}), 3.03$ (m, 1CH, $i \operatorname{Pr}$ ), 2.60 (m, 1CH, $i \operatorname{Pr}), 2.42-2.18$ (m, 13H, 6CH3, $1 \mathrm{CH}, i \operatorname{Pr}), 2.22\left(\mathrm{~m}, 1.64\left(\mathrm{~s}, 3 \mathrm{H}, \mathrm{CH}_{3}\right), 1.52\left(\mathrm{~s}, 3 \mathrm{H}, \mathrm{CH}_{3}\right), 1.34-1.25\left(\mathrm{~m}, 9 \mathrm{H}, 3 \mathrm{CH}_{3}\right), 0.94\left(\mathrm{~s}, 3 \mathrm{H}, \mathrm{CH}_{3}\right)\right.$, $0.86\left(\mathrm{~m}, 6 \mathrm{H}, 2 \mathrm{CH}_{3}\right), 0.63\left(\mathrm{~s}, 3 \mathrm{H}, \mathrm{CH}_{3}\right), 0.23\left(\mathrm{~s}, 3 \mathrm{H}, \mathrm{CH}_{3}\right) .{ }^{13} \mathrm{C} \mathrm{NMR}\left(100.62 \mathrm{MHz}, \mathrm{C}_{6} \mathrm{D}_{6}\right) \delta[\mathrm{ppm}]=$ 169.36, 168.20, 158.77, 155.15, 154.76, 146.33 (br), 145.62, 142.57, 142.32, 135.88 (br), 134.12 (br), 132.75, 132.64, 131.09 (br), 129.54, 129.34, 128.57, 126.84, 126.70, 126.41, 126.17, 125.95, 125.70, 125.16, 125.01, 124.15, 122.97 (br), 29.30 (br), 28.39 (br), 27.21 (br), 26.79 (br), 25.59 (br), 24.03 (br), 22.20, 21.66 (br), 20.19. ${ }^{31} \mathrm{P}\left\{{ }^{1} \mathrm{H}\right\} \mathrm{NMR}\left(162 \mathrm{MHz}, \mathrm{C}_{6} \mathrm{D}_{6}\right) \delta[\mathrm{ppm}]=18.18$ (s). Anal. calc. for $\mathrm{C}_{65} \mathrm{H}_{71} \mathrm{GeN}_{2} \mathrm{OP}: \mathrm{C} 78.08 \%, \mathrm{H} 7.16 \%$, N $2.80 \%$, found: C $78.08 \%, \mathrm{H} 7.19 \%$, N $2.63 \%$.

(IDipp)PSn( ${ }^{\text {Mes }}$ Ter)OC(CPh $)$ (4). Yield: $45 \mathrm{mg}(0.043 \mathrm{mmol}, 80 \%)$.

${ }^{1} \mathrm{H}$ NMR $\left(400 \mathrm{MHz}, \mathrm{C}_{6} \mathrm{D}_{6}\right) \delta[\mathrm{ppm}]=7.36(\mathrm{~m}, 1 \mathrm{H}, \mathrm{Ar}), 7.28-6.82(\mathrm{~m}, 21 \mathrm{H}, \mathrm{Ar}), 6.39$ (br, $\left.1 \mathrm{H}, \mathrm{Ar}\right)$, $6.26(\mathrm{~s}, 1 \mathrm{H}, \mathrm{CHN}), 6.21(\mathrm{~s}, 1 \mathrm{H}, \mathrm{CHN}), 3.31(\mathrm{~m}, 1 \mathrm{CH}, i \operatorname{Pr}), 3.01(\mathrm{~m}, 1 \mathrm{CH}, i \operatorname{Pr}), 2.63$ (m, $1 \mathrm{CH}, i \operatorname{Pr})$, 2.45-2.17 (m, $\left.13 \mathrm{H}, 6 \mathrm{CH}_{3}, 1 \mathrm{CH}, i \operatorname{Pr}\right), 1.79\left(\mathrm{~s}, 3 \mathrm{H}, \mathrm{CH}_{3}\right), 1.54\left(\mathrm{~s}, 3 \mathrm{H}, \mathrm{CH}_{3}\right), 1.34\left(\mathrm{~m}, 6 \mathrm{H}_{2} \mathrm{CH}_{3}\right), 1.24$ $\left(\mathrm{d},{ }^{3} J_{\mathrm{H}, \mathrm{H}}=6.5 \mathrm{~Hz}, 3 \mathrm{H}, \mathrm{CH}_{3}, i \mathrm{Pr}\right), 0.96\left(\mathrm{~d},{ }^{3} J_{\mathrm{H}, \mathrm{H}}=6.5 \mathrm{~Hz}, 3 \mathrm{H}, \mathrm{CH}_{3}, i \operatorname{Pr}\right), 0.83\left(\mathrm{~m}, 6 \mathrm{H}, 2 \mathrm{CH}_{3}\right), 0.67(\mathrm{~d}$, $\left.{ }^{3} J_{\mathrm{H}, \mathrm{H}}=6.5 \mathrm{~Hz}, 3 \mathrm{H}, \mathrm{CH}_{3}, i \mathrm{Pr}\right), 0.28\left(\mathrm{~d},{ }^{3} J_{\mathrm{H}, \mathrm{H}}=6.5 \mathrm{~Hz}, 12 \mathrm{H}, \mathrm{CH}_{3}, i \operatorname{Pr}\right) .{ }^{13} \mathrm{C} \mathrm{NMR}\left(100.62 \mathrm{MHz}, \mathrm{C}_{6} \mathrm{D}_{6}\right)$ $\delta[\mathrm{ppm}]=172.27,170.10,168.9,157.55,157.12,146.86,146.63,145.98,145.05,143.14,143.09$, 142.82, 137.90, 134.01, 133.19, 133.08, 132.71, 132.00, 131.20, 130.93, 129.54, 129.34, 128.57, 126.76, 126.54, 125,70, 125.46, 125.23, 125.01, 124.68, 123.89, 122.62, 29.56, 29.22 (br), 28.22, 27.18, 27.07, 25.88, 25.59, 23.84, 22.02, 21.90 (br), 21.48 (br), 20.20. ${ }^{31} \mathrm{P}\left\{{ }^{1} \mathrm{H}\right\} \mathrm{NMR}\left(162 \mathrm{MHz}, \mathrm{C}_{6} \mathrm{D}_{6}\right) \delta$ [ppm] = $-20.05\left(\mathrm{sSat},{ }^{1} J_{\mathrm{P}, \mathrm{Sn}}=235.5 \mathrm{~Hz}\right) .{ }^{119} \mathrm{Sn}\left\{{ }^{1} \mathrm{H}\right\} \mathrm{NMR}\left(149.18 \mathrm{MHz}, \mathrm{THF}-d_{8}\right) \delta[\mathrm{ppm}]=344.2\left(\mathrm{~d},{ }^{1} J_{\mathrm{Sn}, \mathrm{P}}=253\right.$ Hz). Anal. calc. for $\mathrm{C}_{65} \mathrm{H}_{71} \mathrm{~N}_{2} \mathrm{OPSn}$ : C $74.64 \%$, H $6.84 \%$, N $2.68 \%$, found: C $74.68 \%$, H $6.82 \%$, N $2.50 \%$. 


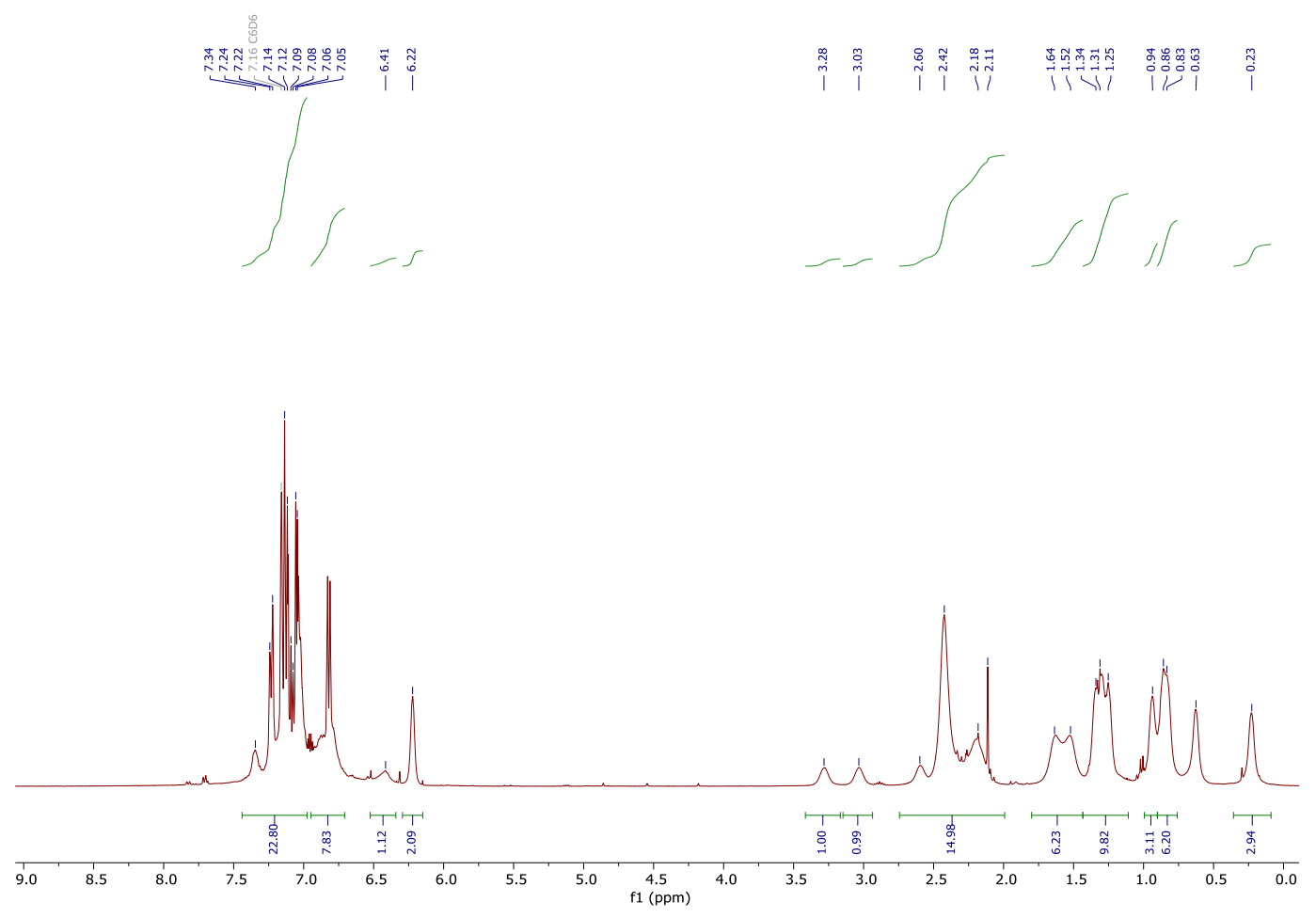

Figure S12. ${ }^{1} \mathrm{H}$ NMR spectrum of heterocycle $3\left(\mathrm{C}_{6} \mathrm{D}_{6}\right)$.

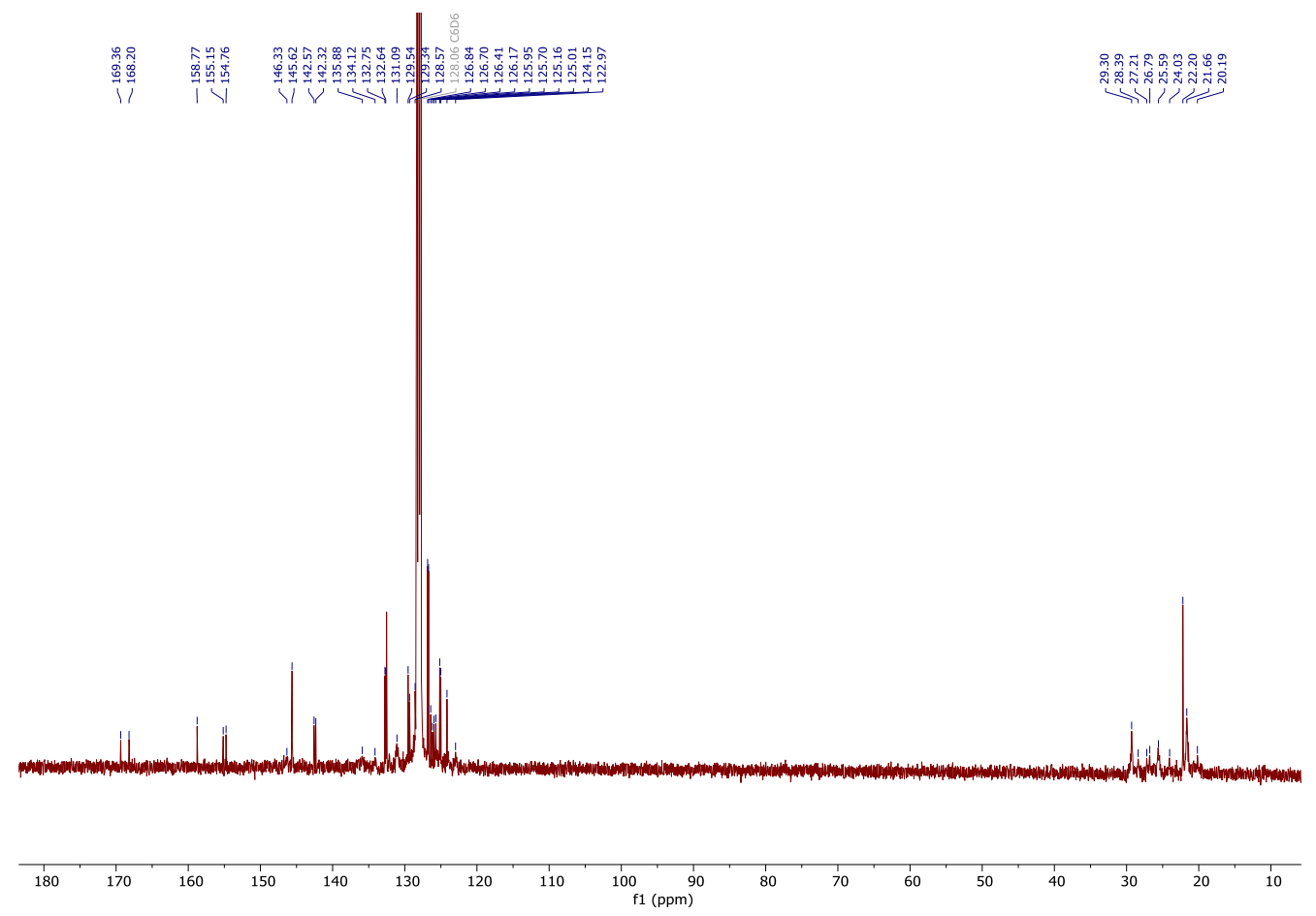

Figure S13. ${ }^{13} \mathrm{C}$ NMR spectrum of heterocycle $3\left(\mathrm{C}_{6} \mathrm{D}_{6}\right)$. 


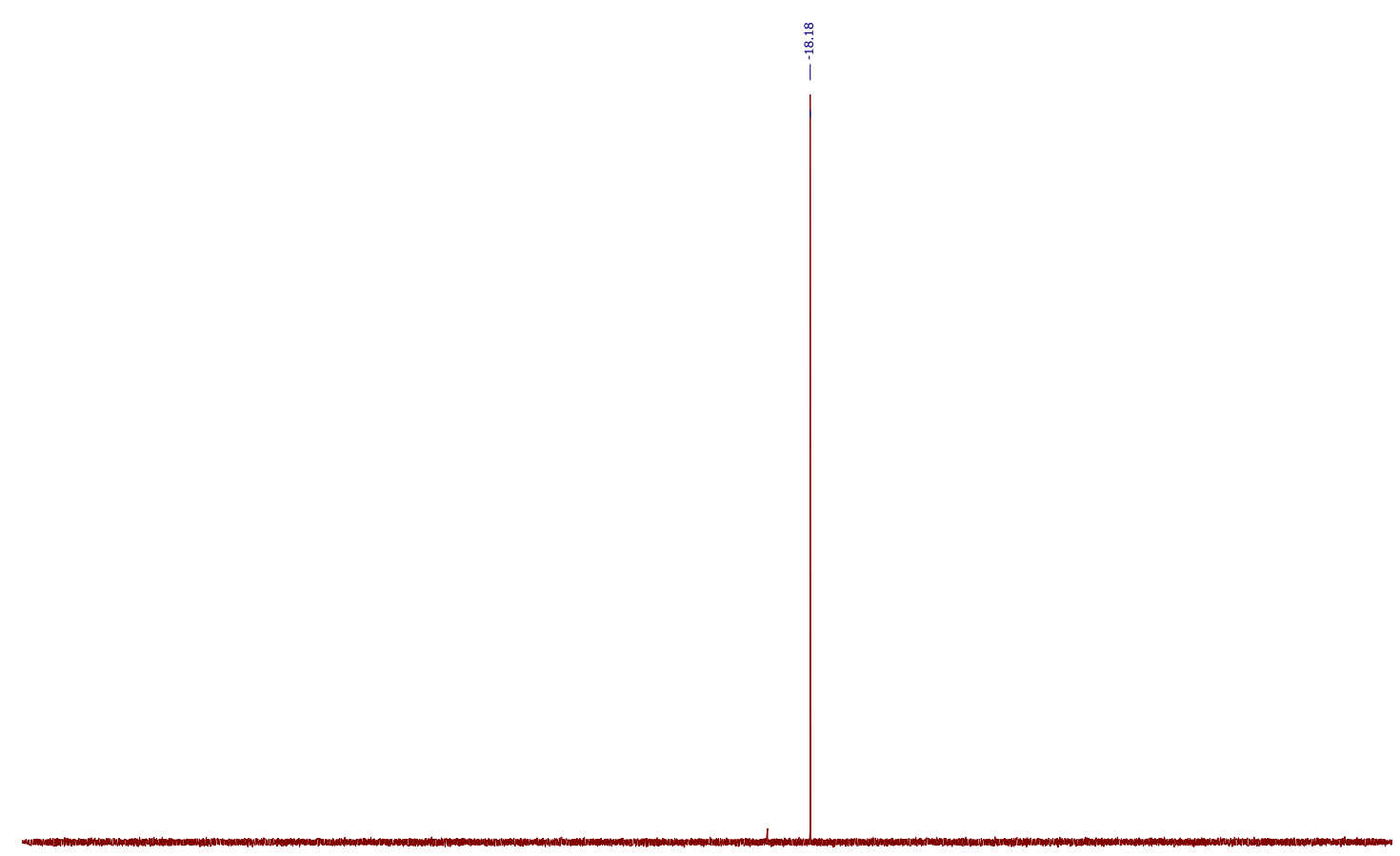

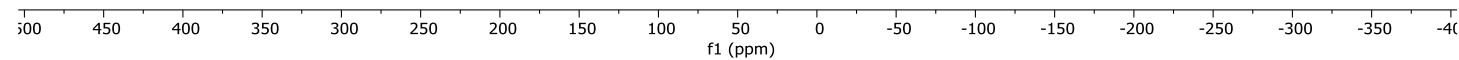

Figure S14. ${ }^{31} \mathrm{P}\left\{{ }^{1} \mathrm{H}\right\}$ NMR spectrum of heterocycle $3\left(\mathrm{C}_{6} \mathrm{D}_{6}\right)$.

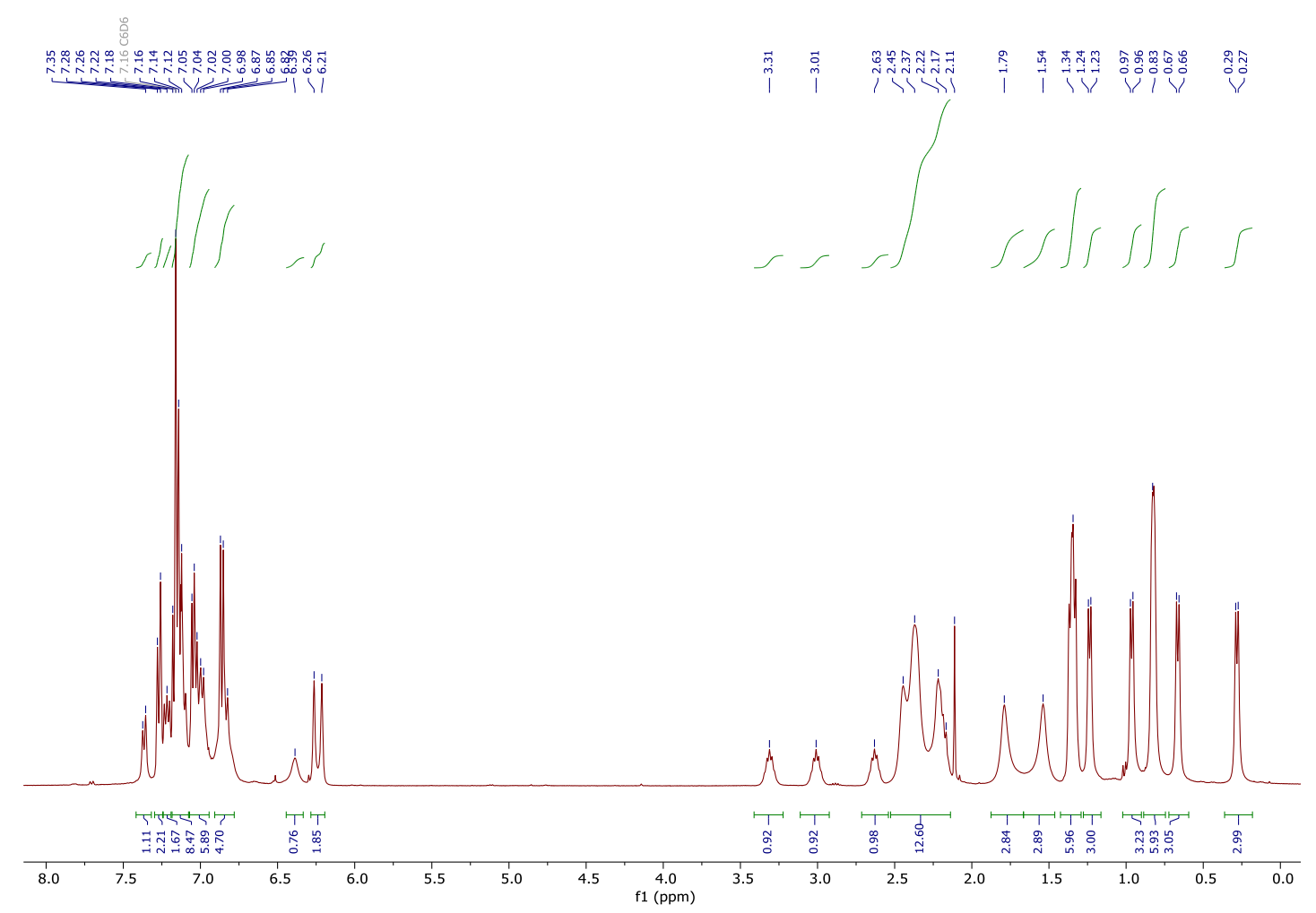

Figure S15. ${ }^{1} \mathrm{H}$ NMR spectrum of heterocycle $4\left(\mathrm{C}_{6} \mathrm{D}_{6}\right)$. 


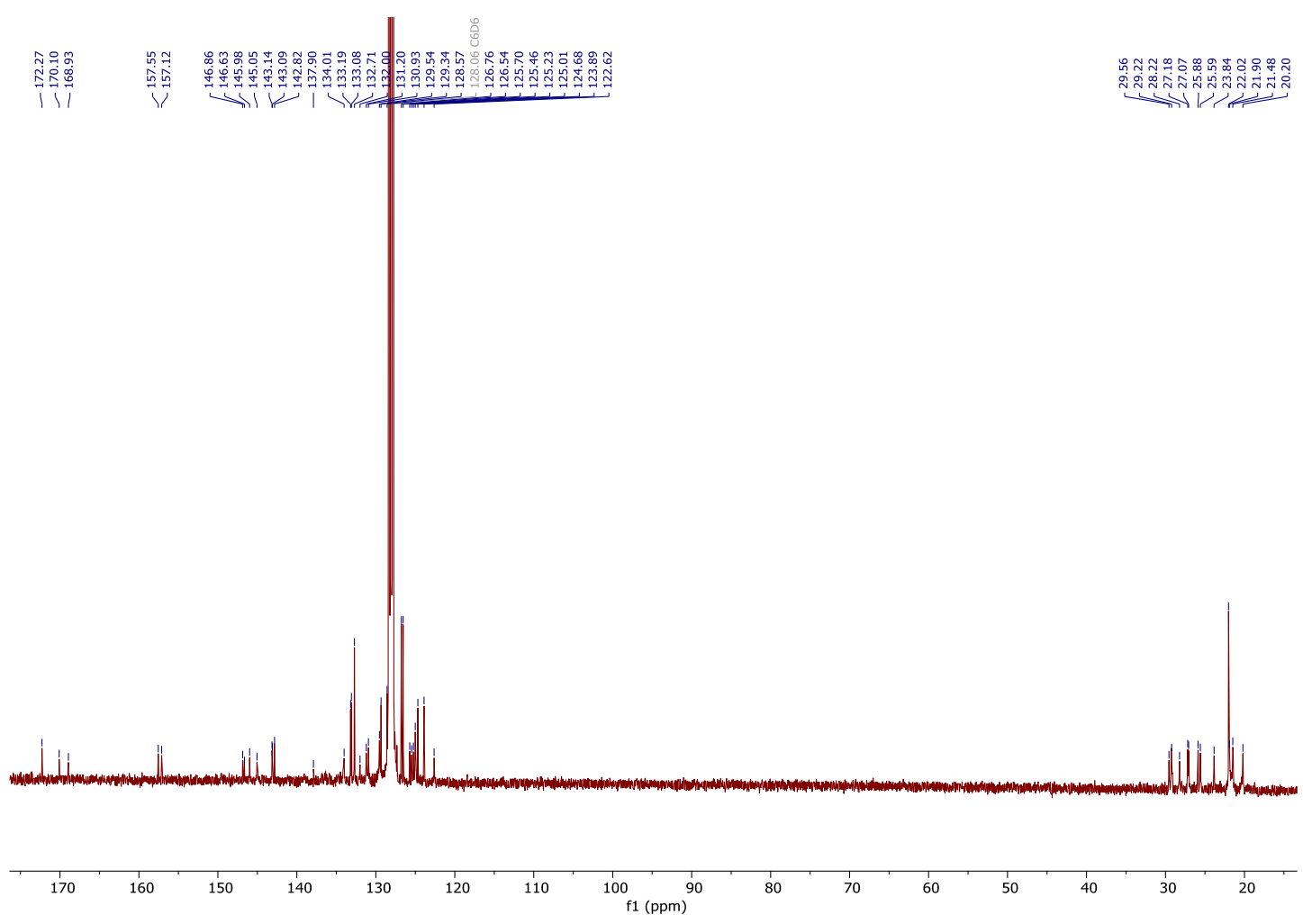

Figure S16. ${ }^{13} \mathrm{C}$ NMR spectrum of heterocycle $4\left(\mathrm{C}_{6} \mathrm{D}_{6}\right)$.

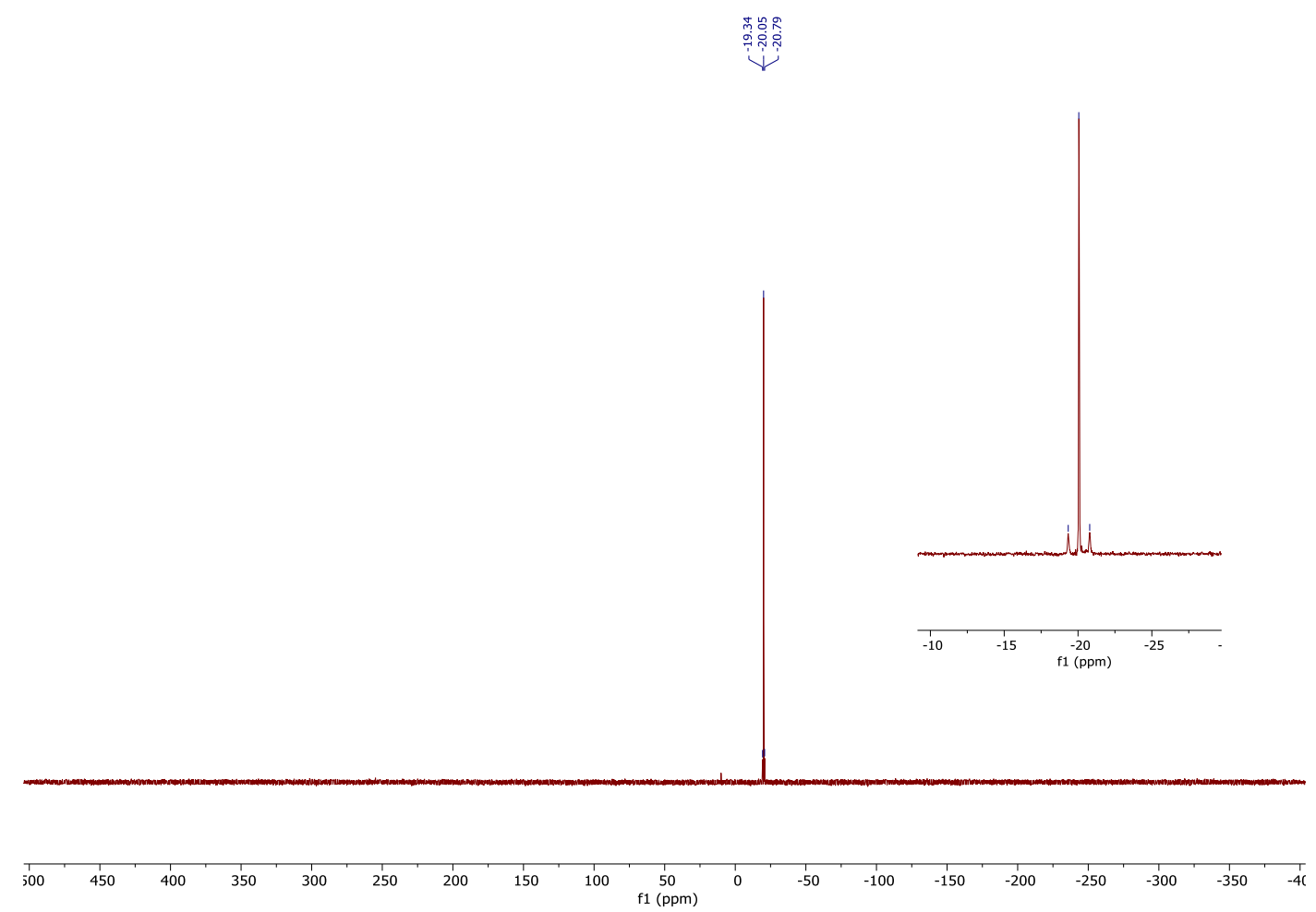

Figure S17. ${ }^{31} \mathrm{P}\left\{{ }^{1} \mathrm{H}\right\}$ NMR spectrum of heterocycle $4\left(\mathrm{C}_{6} \mathrm{D}_{6}\right)$. 


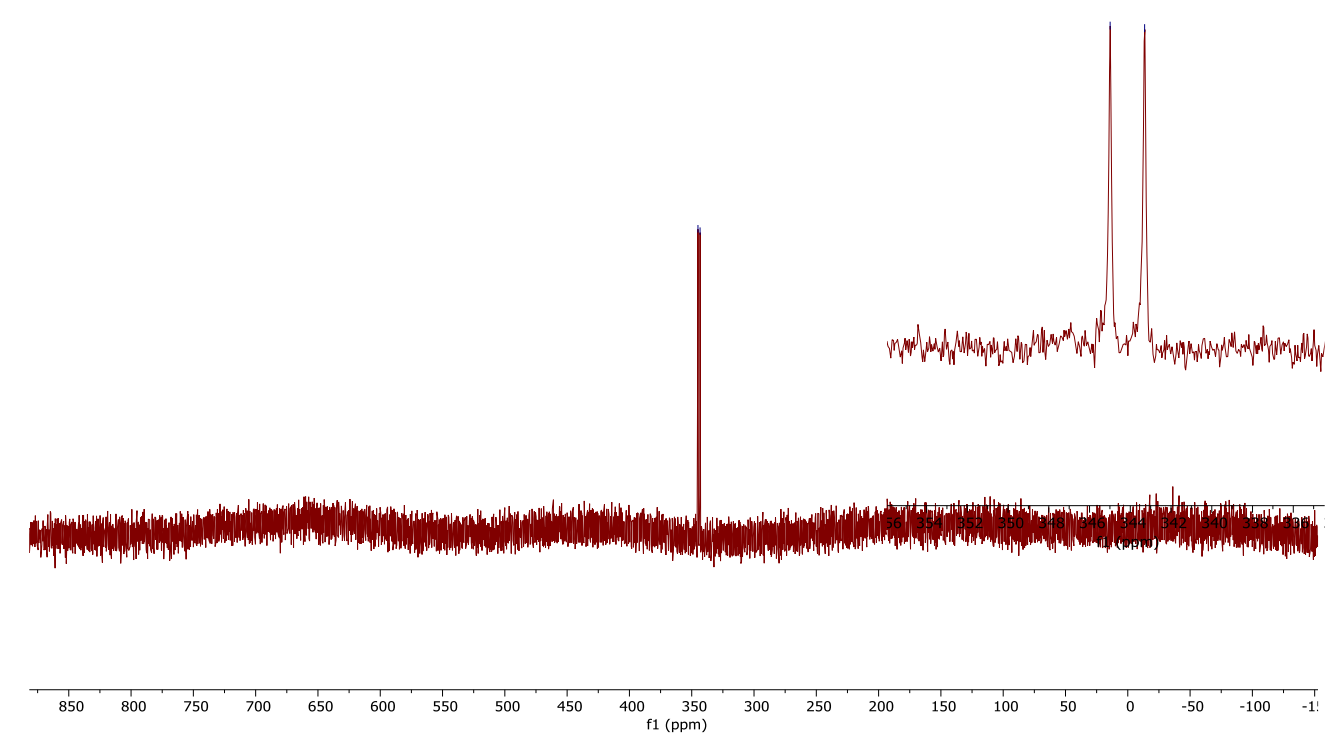

Figure S18. ${ }^{119} \mathrm{Sn}\left\{{ }^{1} \mathrm{H}\right\}$ NMR spectrum of heterocycle 4 (THF- $d 8$ ).

Thermally induced retrocycloaddition of 3 and 4.

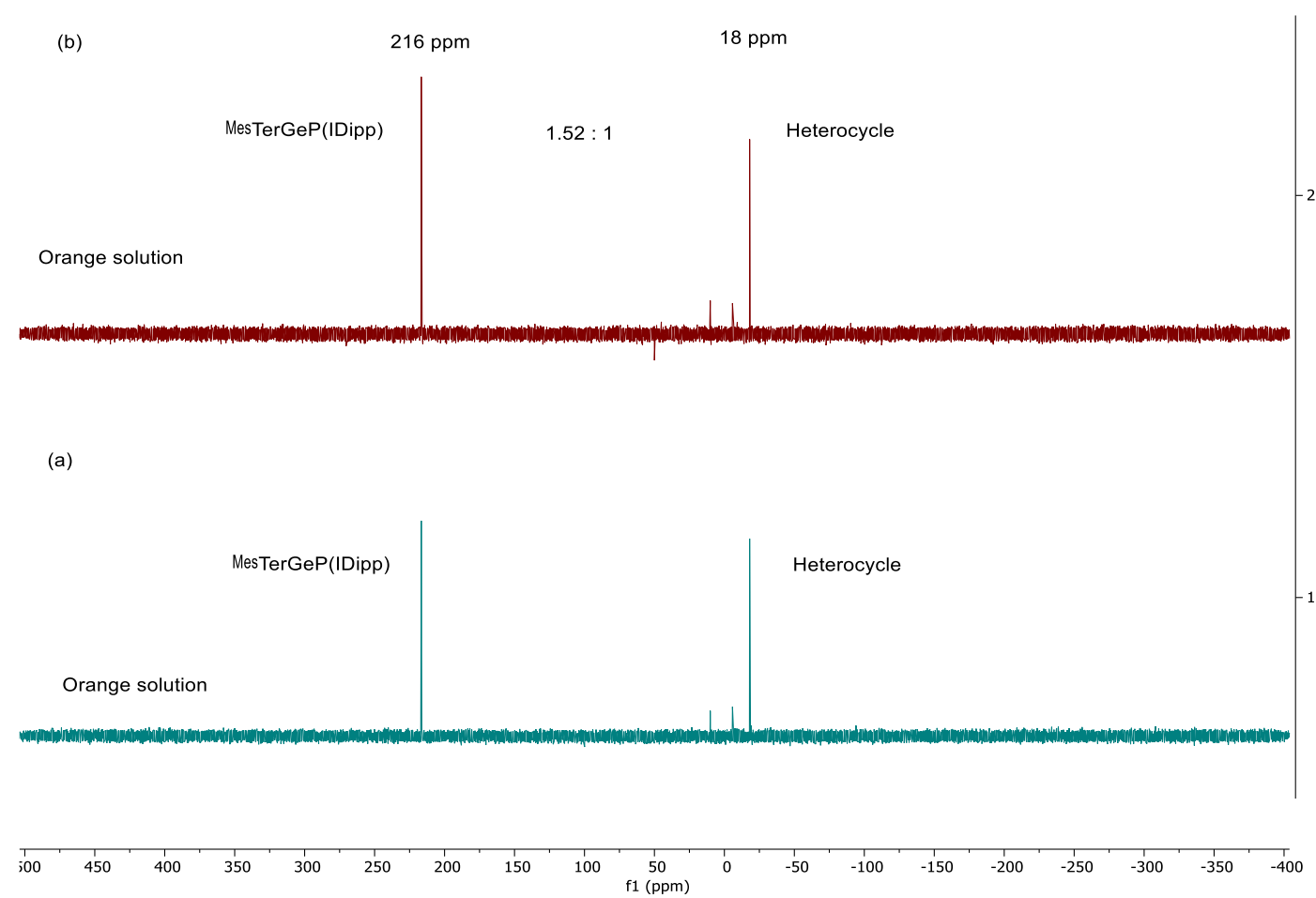

Figure S19. ${ }^{31} \mathrm{P}\left\{{ }^{1} \mathrm{H}\right\}$ NMR Spectra $\left(\mathrm{C}_{6} \mathrm{D}_{6}, \mathrm{rt}\right)$ of heterocycle 3: (a) after heating at $75{ }^{\circ} \mathrm{C}$ for $16 \mathrm{~h}$; (b) next spectrum after being at $\mathrm{rt}$ for $24 \mathrm{~h}$ (no significant changes due to thermal decomposition of $\mathrm{Ph}_{2} \mathrm{CCO}$ ). 


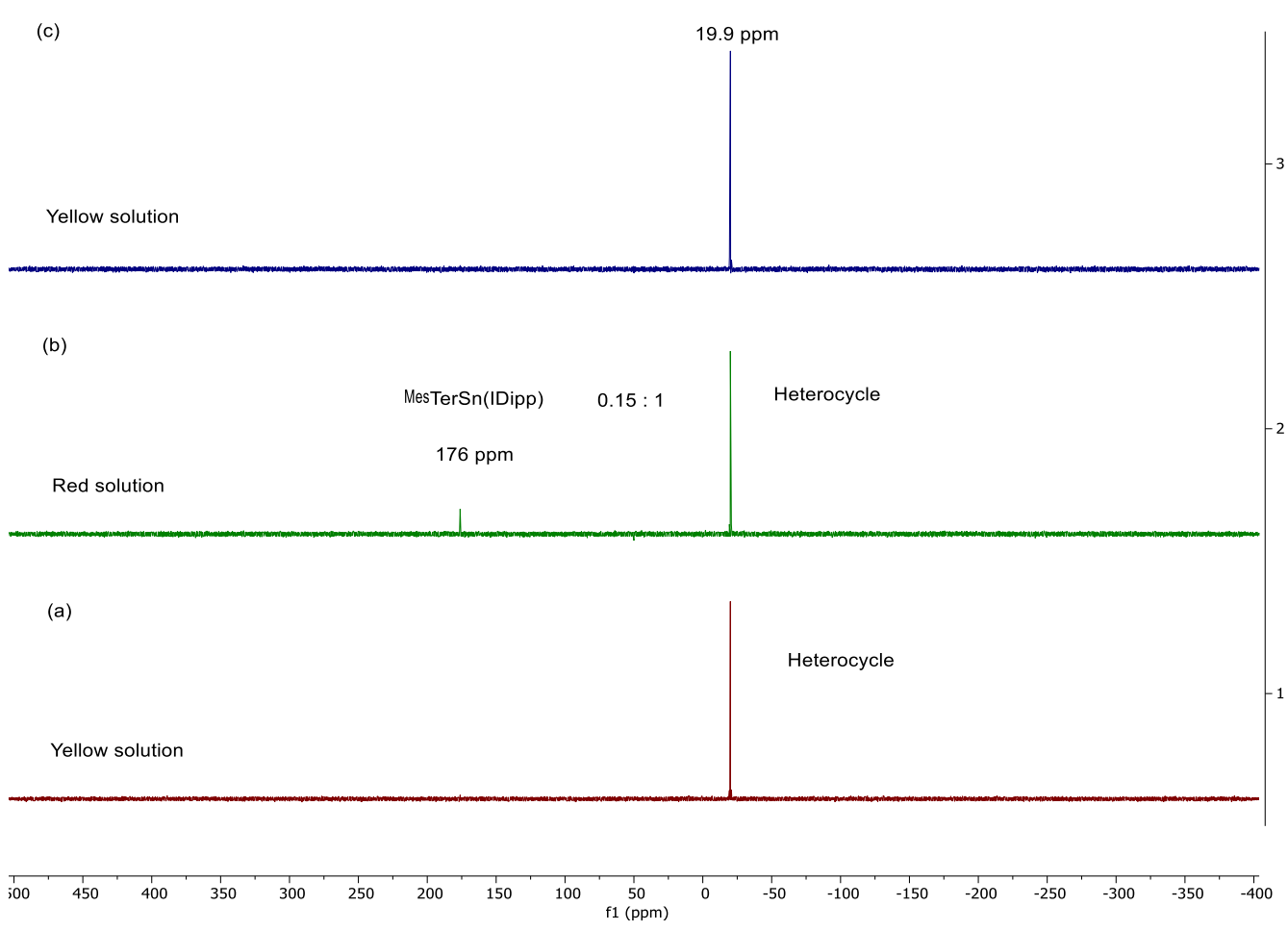

Figure S20. ${ }^{31} \mathrm{P}\left\{{ }^{1} \mathrm{H}\right\}$ NMR spectra $\left(\mathrm{C}_{6} \mathrm{D}_{6}, \mathrm{rt}\right)$ of heterocycle 4: (a) after heating at $80{ }^{\circ} \mathrm{C}$ for $48 \mathrm{~h}$; (b) after following heating for $15 \mathrm{~min}$ at $100{ }^{\circ} \mathrm{C}$; (c) after being at rt for $2 \mathrm{~h}$.

Synthesis of (IDipp)PSn $\left.{ }^{\text {Mes }}{ }^{T e r}\right)\left[C_{6} F_{4} B(F)\left(C_{6} F_{5}\right)_{2}\right.$ (5). A mixture of 2 (40 mg, $\left.0.0469 \mathrm{mmol}\right)$ and $\mathrm{B}\left(\mathrm{C}_{6} \mathrm{~F}_{5}\right)_{3}(25 \mathrm{mg}, 0.049 \mathrm{mmol})$ was heated in benzene $(2 \mathrm{~mL})$ for $16 \mathrm{~h}$. Obtained red crystals were filtered off and washed consequently with benzene $(5 \mathrm{~mL})$ and $n$-pentane $(7 \mathrm{~mL})$. Yield: $38 \mathrm{mg}(0.027 \mathrm{mmol}$, $60 \%)$.

${ }^{1} \mathrm{H}$ NMR $\left(400 \mathrm{MHz}, \mathrm{THF}-d_{8}\right) \delta[\mathrm{ppm}]=7.74(\mathrm{~s}, 2 \mathrm{H}, 2 \mathrm{NCH}), 7.56\left(\mathrm{t},{ }^{3} \mathrm{~J}_{\mathrm{H}, \mathrm{H}}=7.8 \mathrm{~Hz}, 2 \mathrm{H}, \mathrm{CH}, p-\mathrm{C}_{6} \mathrm{H}_{3}\right.$, Dipp), 7.42 (m, 1H, CH, $p$ - $\left.\mathrm{C}_{6} \mathrm{H}_{3},{ }^{\text {Mes }} \mathrm{Ter}\right), 7.41\left(\mathrm{~d},{ }^{3} J_{\mathrm{H}, \mathrm{H}}=7.7 \mathrm{~Hz}, 4 \mathrm{H}, \mathrm{CH}, m-\mathrm{C}_{6} \mathrm{H}_{3}, \mathrm{Dipp}\right), 6.92\left(\mathrm{~d},{ }^{3} J_{\mathrm{H}, \mathrm{H}}\right.$ $=7.5 \mathrm{~Hz}, 2 \mathrm{H}, \mathrm{CH}, m-\mathrm{C}_{6} \mathrm{H}_{3}$, ${ }^{\mathrm{Mes}} \mathrm{Ter}$ ), 6.63 (s, 4H, CH, $m$-Mes), 2.63 (hept, ${ }^{3} J_{\mathrm{H}, \mathrm{H}}=6.8 \mathrm{~Hz}, 4 \mathrm{H}, \mathrm{CH}, i \operatorname{Pr}$ ), $2.16\left(\mathrm{~s}, 6 \mathrm{H}, p-\mathrm{CH}_{3}, \mathrm{Mes}\right), 1.84\left(\mathrm{~s}, 12 \mathrm{H}, o-\mathrm{CH}_{3}, \mathrm{Mes}\right), 1.22\left(\mathrm{~d},{ }^{3} J_{\mathrm{H}, \mathrm{H}}=6.8 \mathrm{~Hz}, 12 \mathrm{H}, \mathrm{CH}_{3}, i \mathrm{Pr}\right), 1.10(\mathrm{~d}$, $\left.{ }^{3} J_{\mathrm{H}, \mathrm{H}}=6.9 \mathrm{~Hz}, 12 \mathrm{H}, \mathrm{CH}_{3}, i \mathrm{Pr}\right) .{ }^{13} \mathrm{C} \mathrm{NMR}\left(100.62 \mathrm{MHz}, \mathrm{THF}-d_{8}\right) \delta[\mathrm{ppm}]=163.24,161.76,150.35$, 149.34, 148.08 (br), 147.38, 145.49 (br), 140.76 (br), 140.22, 138.87 (br), 138.53, 137.30, 136.27 (br), 134.95, 132.20, 131.31, 130.85, 129.87, 127.70 (s, NCH), 125.74, 30.37 (s, CH, $i \mathrm{Pr}$ ), 30.32 (s, CH, $i \mathrm{Pr}$ ),

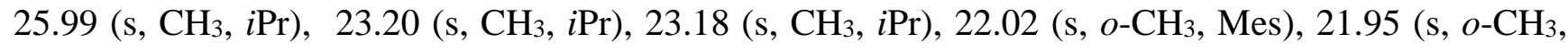
Mes), 21.09 (s, $p-\mathrm{CH}_{3}$, Mes). ${ }^{31} \mathrm{P}\left\{{ }^{1} \mathrm{H}\right\}$ NMR (162 MHz, THF- $\left.d 8\right) \delta[\mathrm{ppm}]=-93.01$ (ssat, ${ }^{1} J^{119} \mathrm{Sn}, \mathrm{P}=$ $\left.3046.5 \mathrm{~Hz},{ }^{1} J^{117} \mathrm{Sn}, \mathrm{P}=2917.9 \mathrm{~Hz}\right) .{ }^{119} \mathrm{Sn}\left\{{ }^{1} \mathrm{H}\right\} \mathrm{NMR}(149 \mathrm{MHz}, \mathrm{THF}-d 8) \delta[\mathrm{ppm}]=152.2\left(\mathrm{~d},{ }^{1} J_{\mathrm{Sn}, \mathrm{P}}=\right.$ $3069.6 \mathrm{~Hz}) .{ }^{11} \mathrm{~B}\left\{{ }^{1} \mathrm{H}\right\}$ NMR $(128 \mathrm{MHz}, \mathrm{THF}-d 8) \delta[\mathrm{ppm}]=0.56 .{ }^{19} \mathrm{~F}\left\{{ }^{1} \mathrm{H}\right\} \mathrm{NMR}(128 \mathrm{MHz}, \mathrm{THF}-d 8) \delta$ $[\mathrm{ppm}]=-193.2(\mathrm{~s}),-168.54(\mathrm{~m}),-164.8\left(\mathrm{t}, J_{\mathrm{F}, \mathrm{F}}=20.0 \mathrm{~Hz}\right),-134.4(\mathrm{~m}),-132.7(\mathrm{~m}),-121.8(\mathrm{~s})$. FT-IR (neat), $\tilde{v}\left[\mathrm{~cm}^{-1}\right]=2966(\mathrm{~m}), 1641(\mathrm{~s}), 1512(\mathrm{~m}), 1458(\mathrm{w}), 1425(\mathrm{w}), 1219(\mathrm{w}), 1085(\mathrm{w}), 964(\mathrm{w}), 751$ 
(m), 677 (w). Anal. calc. for $\mathrm{C}_{69} \mathrm{H}_{61} \mathrm{BF}_{15} \mathrm{~N}_{2} \mathrm{PSn}: \mathrm{C} 60.77 \%, \mathrm{H} 4.51 \%, \mathrm{~N} 2.05 \%$, found: $\mathrm{C} 60.19 \%, \mathrm{H}$ $4.82 \%, \mathrm{~N} 2.01 \%$.

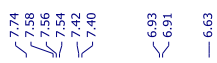

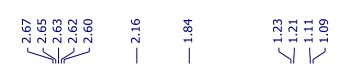
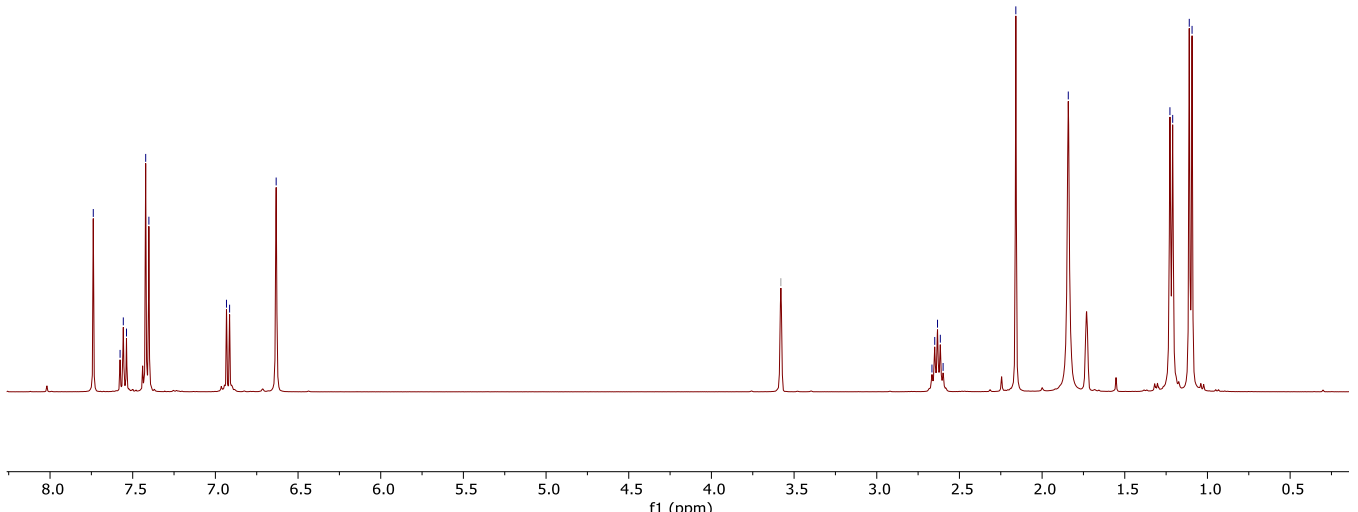

Figure S21. ${ }^{1} \mathrm{H}$ NMR spectrum of phosphastannene 5 (THF- $\left.d 8\right)$.

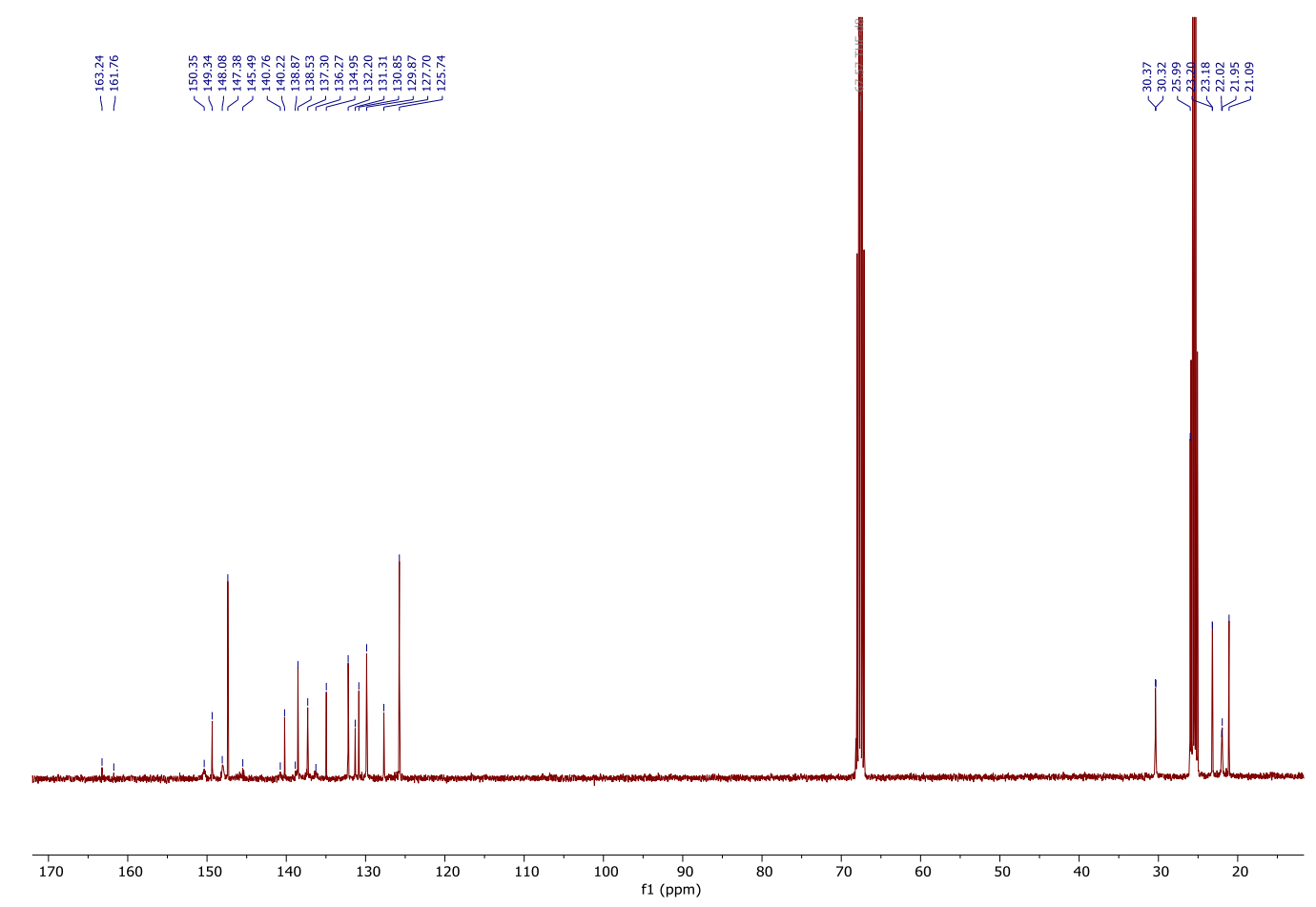

Figure S22. ${ }^{13} \mathrm{C}$ NMR spectrum of phosphastannene 5 (THF- $d 8$ ). 


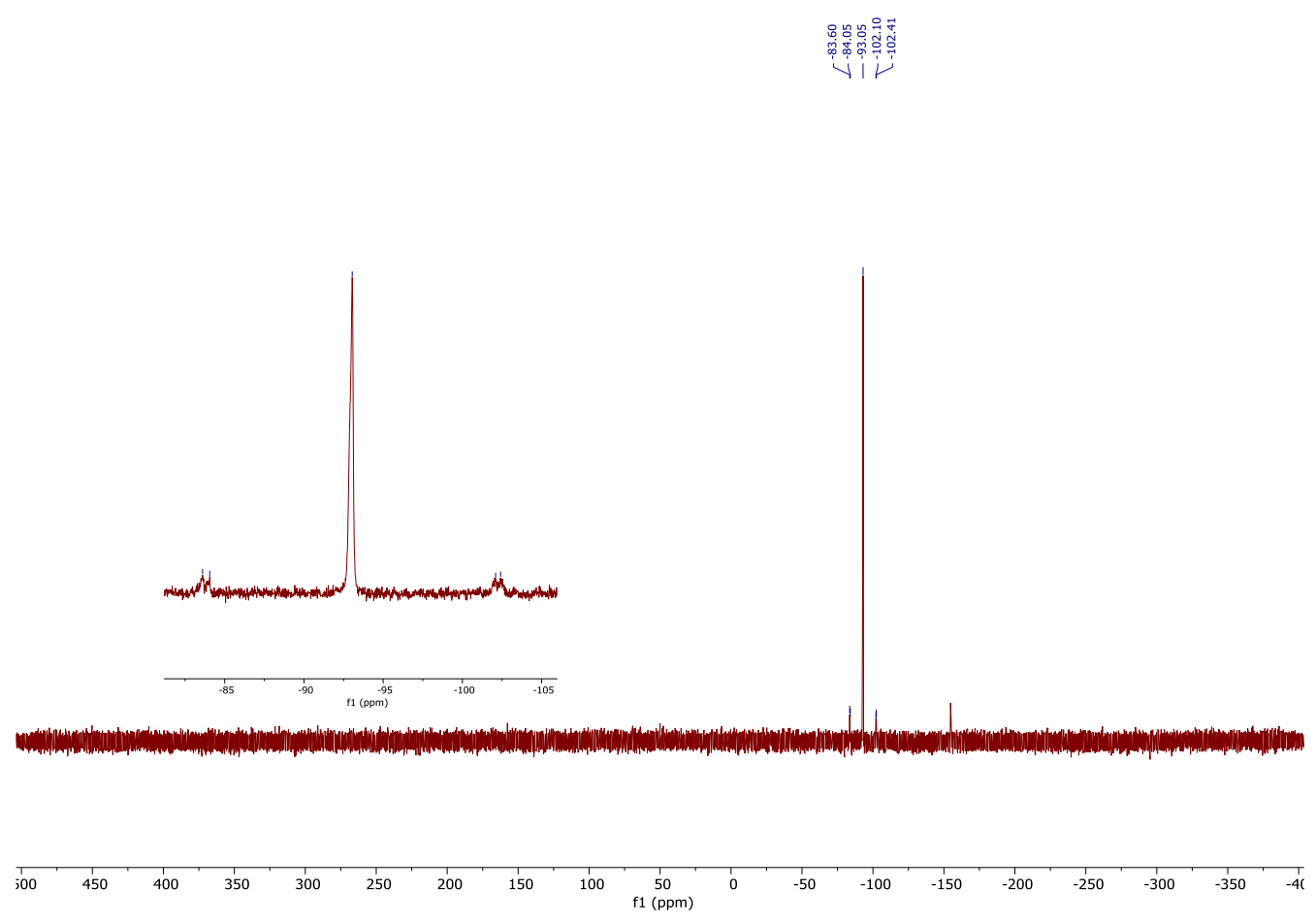

Figure S23. ${ }^{31} \mathrm{P}\left\{{ }^{1} \mathrm{H}\right\}$ NMR spectrum of phosphastannene 5 (THF- $\left.d_{8}\right)$

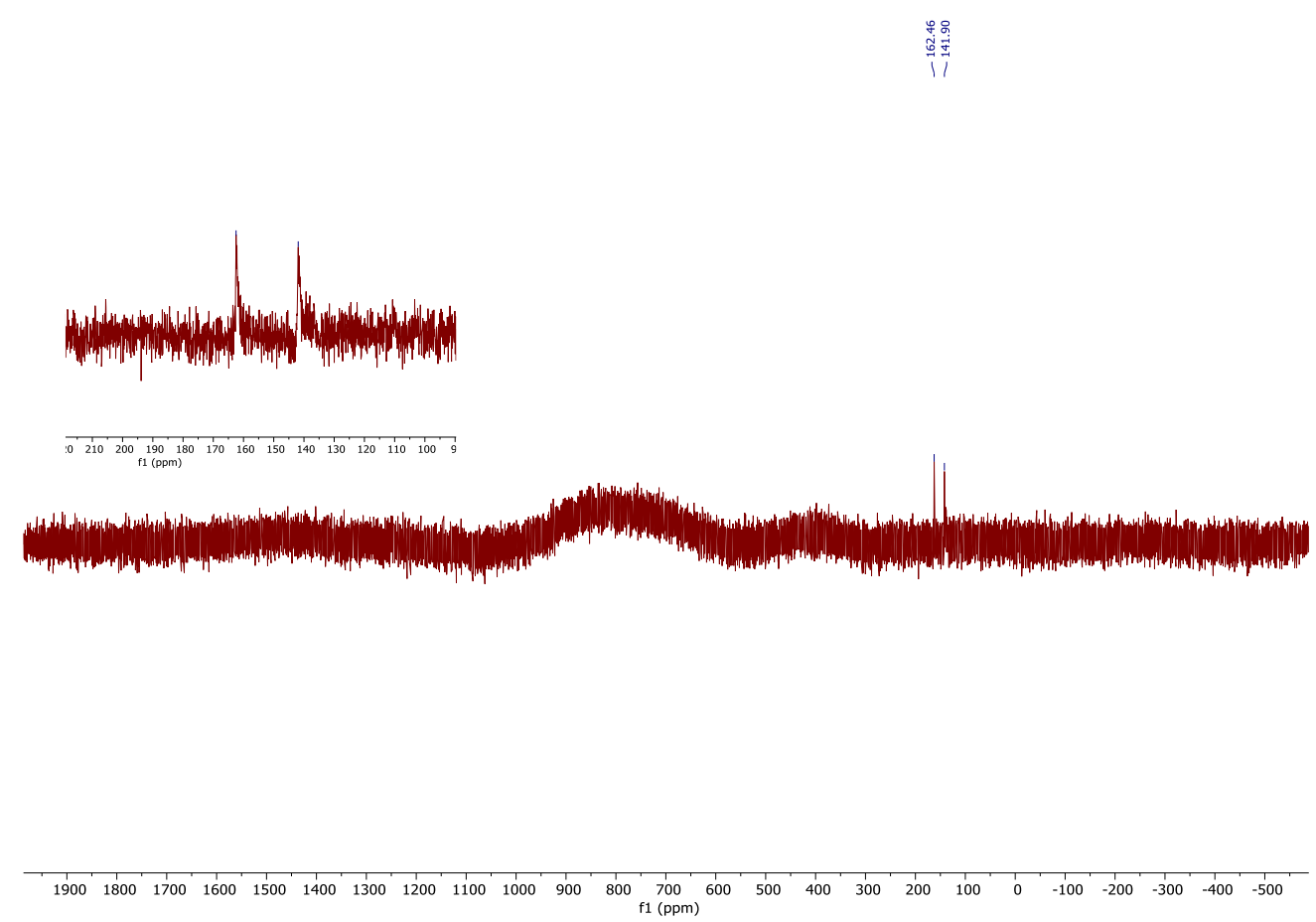

Figure S24. ${ }^{119} \mathrm{Sn}\left\{{ }^{1} \mathrm{H}\right\}$ NMR spectrum of phosphastannene 5 (THF- $d_{8}$ ) 


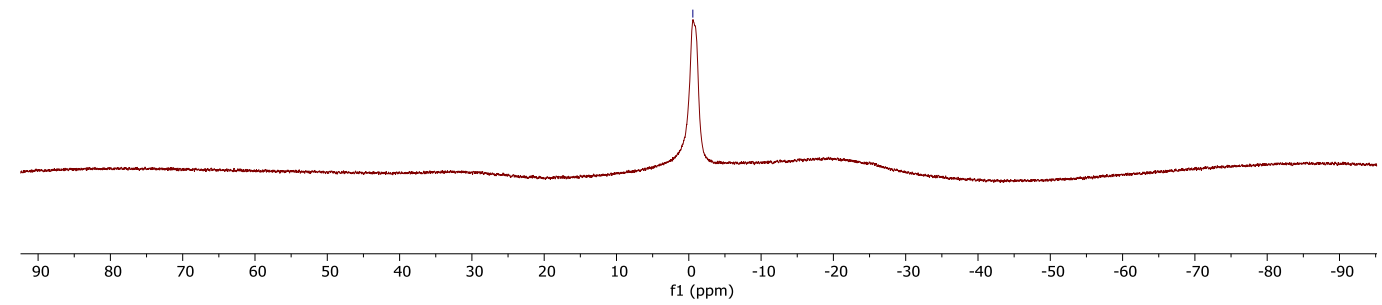

Figure S25. ${ }^{11} \mathrm{~B}\left\{{ }^{1} \mathrm{H}\right\}$ NMR spectrum of phosphastannene 5 (THF- $d 8$ ).

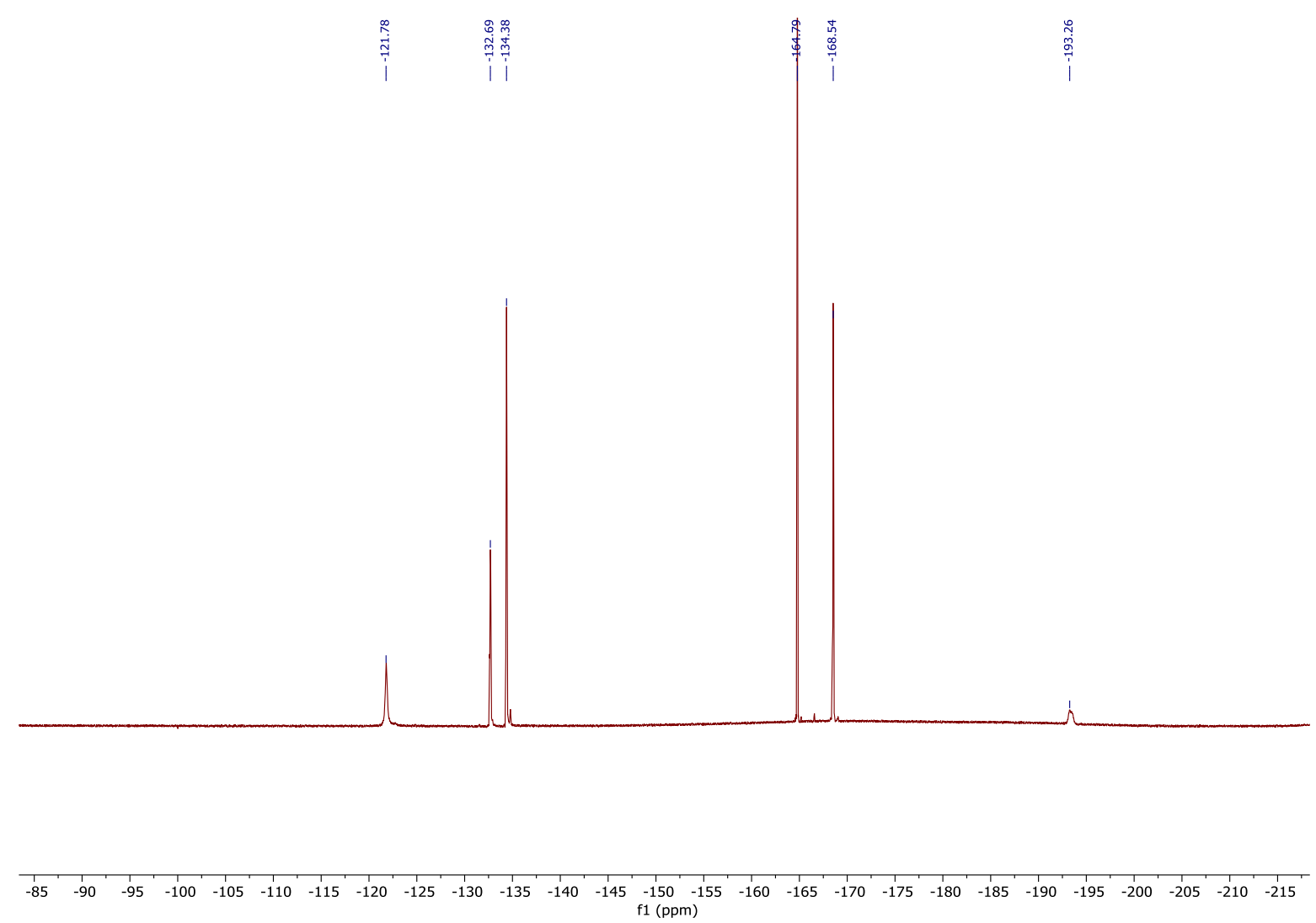

Figure S26. ${ }^{19} \mathrm{~F}\left\{{ }^{1} \mathrm{H}\right\}$ NMR spectrum of phosphastannene 5 (THF- $\left.d_{8}\right)$. 


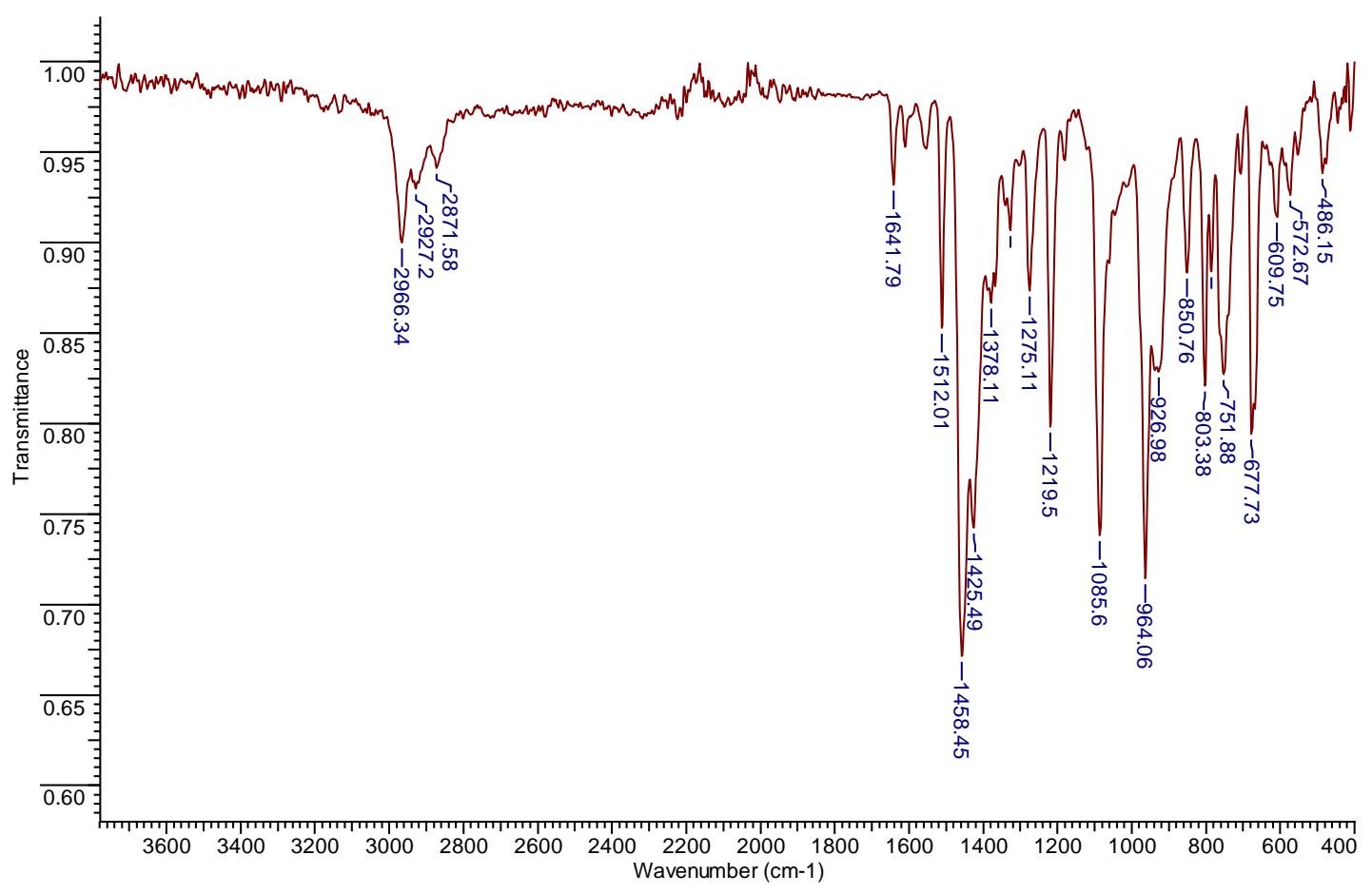

Figure S27. FT-IR spectrum of phosphastannene 5.

Reaction of Mes TerGeP(IDipp) (1) with tris(pentafluorophenyl)borane. The mixture of 1 (76 mg, $0.0943 \mathrm{mmol})$ and $\mathrm{B}\left(\mathrm{C}_{6} \mathrm{~F}_{5}\right)_{3}(48.3 \mathrm{mg}, 0.0943 \mathrm{mmol})$ was heated in toluene $(3.5 \mathrm{~mL})$ at $65{ }^{\circ} \mathrm{C}$ for $17 \mathrm{~h}$ to give a dark green solution. Toluene was removed, the product was extracted with $n$-pentane to give a dark green solid (76 mg) which was characterized spectroscopically. Crystallization of the product from $n$-pentane was not successful.

Addition of $n$-pentane to the product during the work up or crystallization led to the formation of some amounts of white precipitate (a complex mixture of unidentified compounds) which was filtered off. 


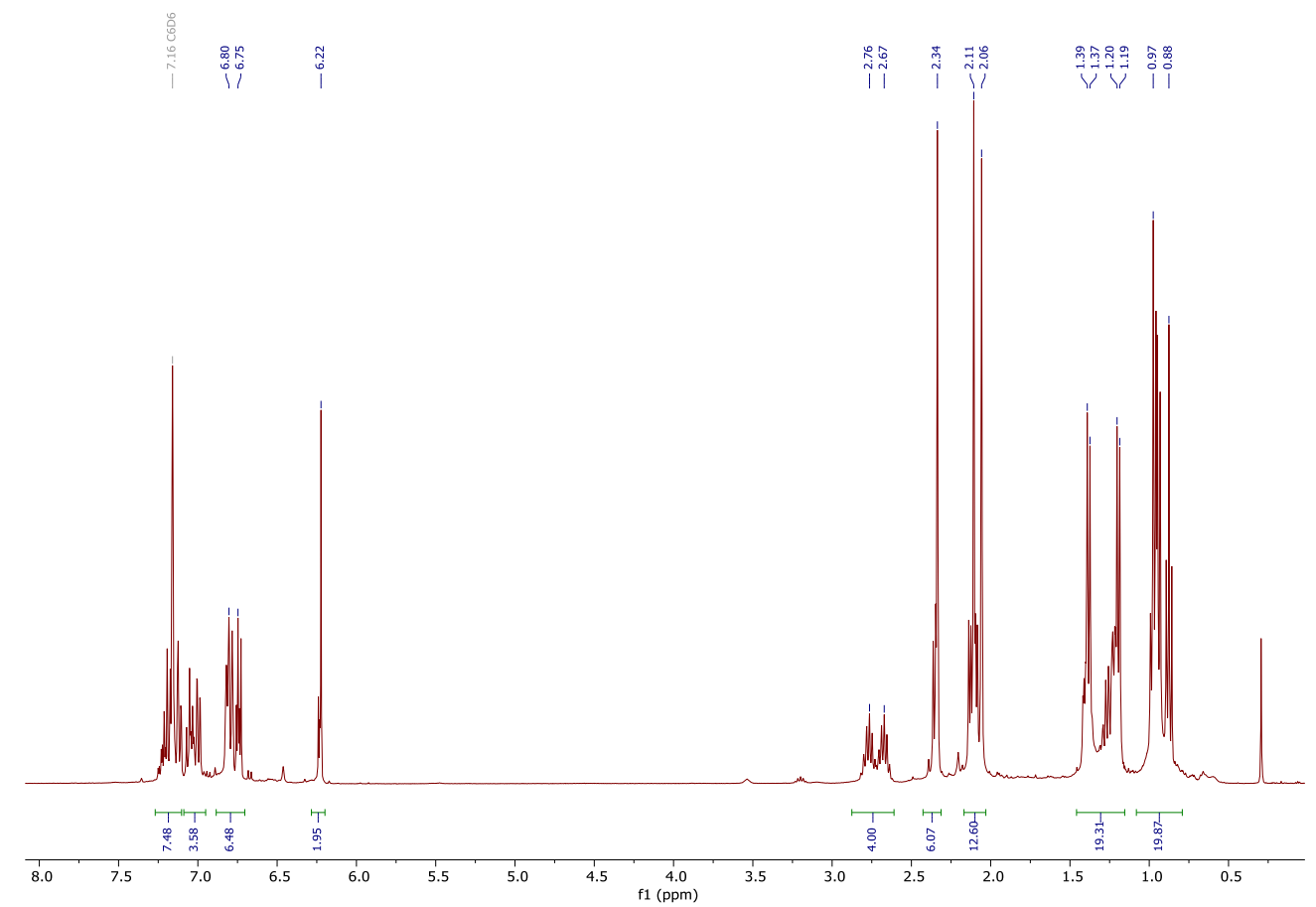

Figure S28. ${ }^{1} \mathrm{H}$ NMR spectrum of the dark green product from the reaction of $\mathbf{1}$ with $\mathrm{BCF}\left(\mathrm{C}_{6} \mathrm{D}_{6}\right)$.
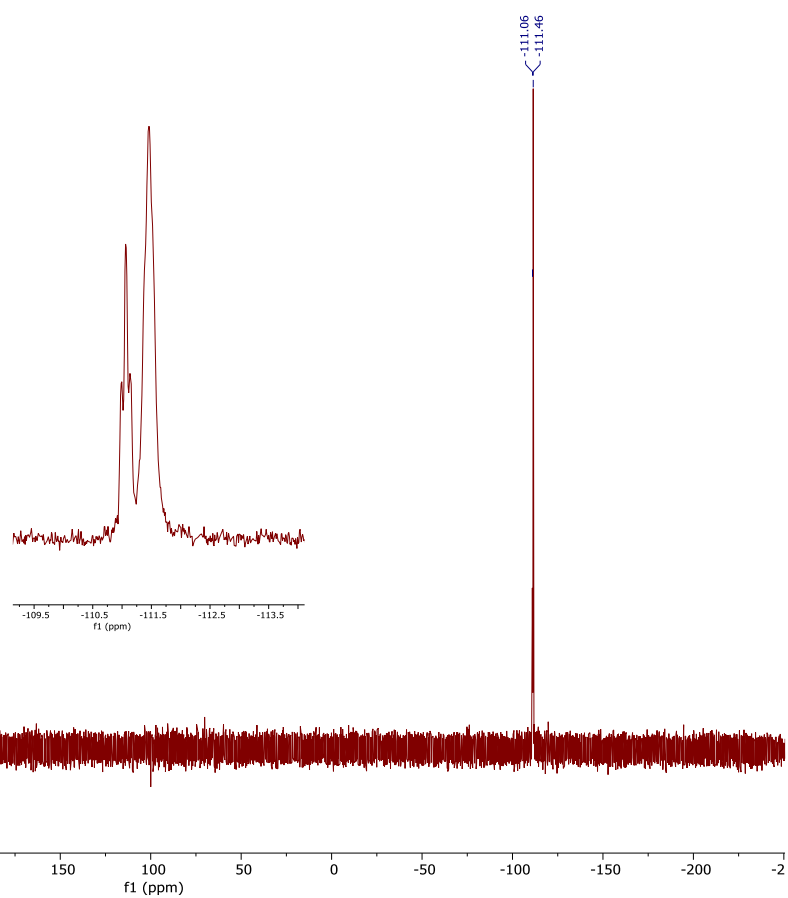

Figure S29. ${ }^{31} \mathrm{P}\left\{{ }^{1} \mathrm{H}\right\}$ NMR spectrum of the dark green product from the reaction of $\mathbf{1}$ with $\mathrm{BCF}\left(\mathrm{C}_{6} \mathrm{D}_{6}\right)$. 


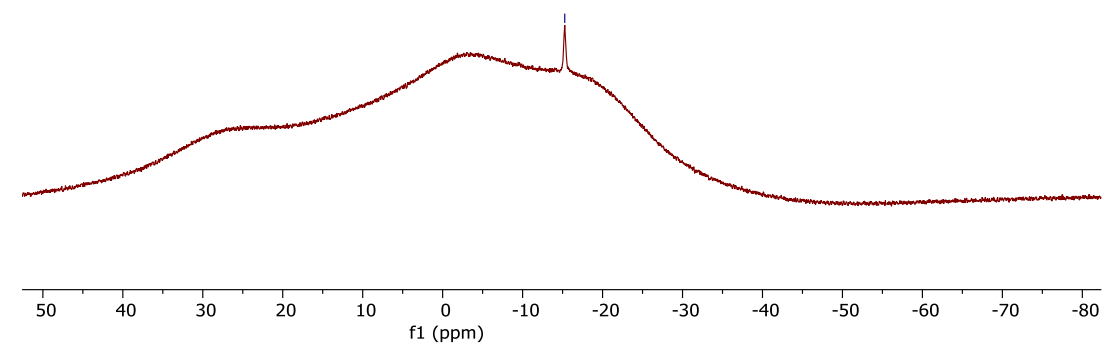

Figure S30. ${ }^{31} \mathrm{P}\left\{{ }^{1} \mathrm{H}\right\}$ NMR spectrum of the dark green product from the reaction of 1 with $\mathrm{BCF}\left(\mathrm{C}_{6} \mathrm{D}_{6}\right)$.

\section{Catalysis studies}

General procedures for catalytic hydroboration of aromatic aldehydes and ketones in the presense of tetrylene-phosphinidene complexes 2 and 1.

Catalyst loadings $0.05-0.1 \mathrm{~mol} \%$ : pinacol borane $(0.55 \mathrm{mmol})$ was added to a solution of carbonyl compound $(0.5 \mathrm{mmol})$ in $\mathrm{C}_{6} \mathrm{D}_{6}(0.4 \mathrm{~mL})$ in NMR tube. After shaking, solution $\left(11.74 \times 10^{-3} \mathrm{M}\right)$ of the catalyst $\mathbf{2}$ or $\mathbf{1}$ was added, obtained colored solution was well shaken again. NMR spectra were recorded. After reaction completion formation of discolored solutions was observed suggesting destruction of the catalyst.

Catalyst loading $0.5 \mathrm{~mol} \%$ : pinacol borane $(0.55 \mathrm{mmol})$ was added to a solution of carbonyl compound $(0.5 \mathrm{mmol})$ and catalyst 2 in $\mathrm{C}_{6} \mathrm{D}_{6}(0.4 \mathrm{~mL})$ in NMR tube. After shaking, the solution of catalyst 2 or $\mathbf{1}$ was added and obtained colored solution was well shaken again. For catalyst loadings 2-4 mol \% reactions were performed in the same way but using $0.117 \mathrm{mmol}$ of carbonyl compound. 
Reduction of benzaldehyde in the presence of (IDipp)PH. (IDipp)PH (3.4 mg, $0.008 \mathrm{mmol}, 4 \mathrm{~mol} \%$ ) was added to the solution of benzaldehyde $(20 \mu \mathrm{L}, 0.2 \mathrm{mmol})$ and pinacolborane $(30.5 \mu \mathrm{L}, 0.21 \mathrm{mmol})$. The sample was periodically shaken, NMR spectra were recorded.
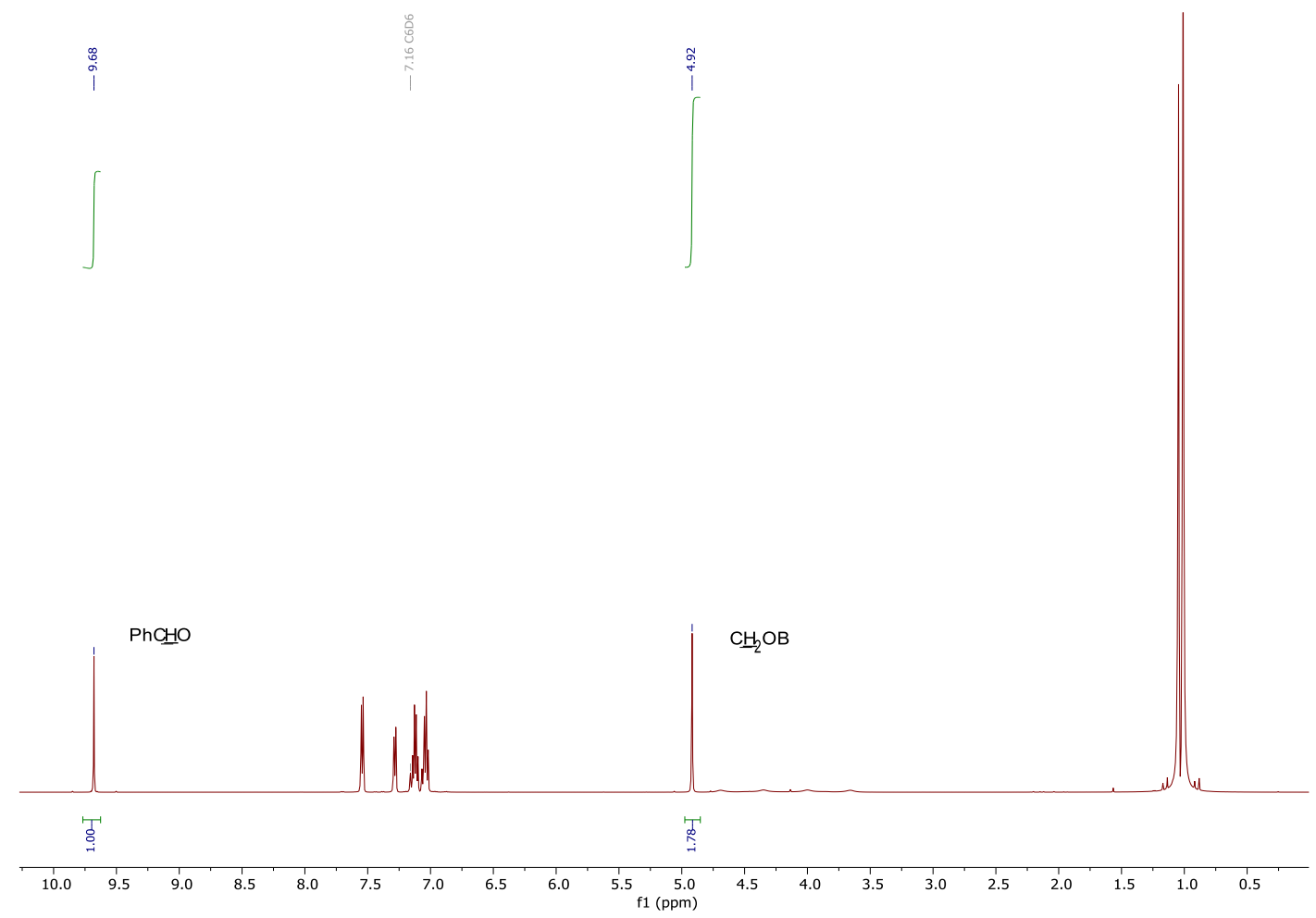

Figure S31. ${ }^{1} \mathrm{H}$ NMR spectrum of the benzaldehyde reduction $(0.05 \mathrm{~mol} \%$ of 2).

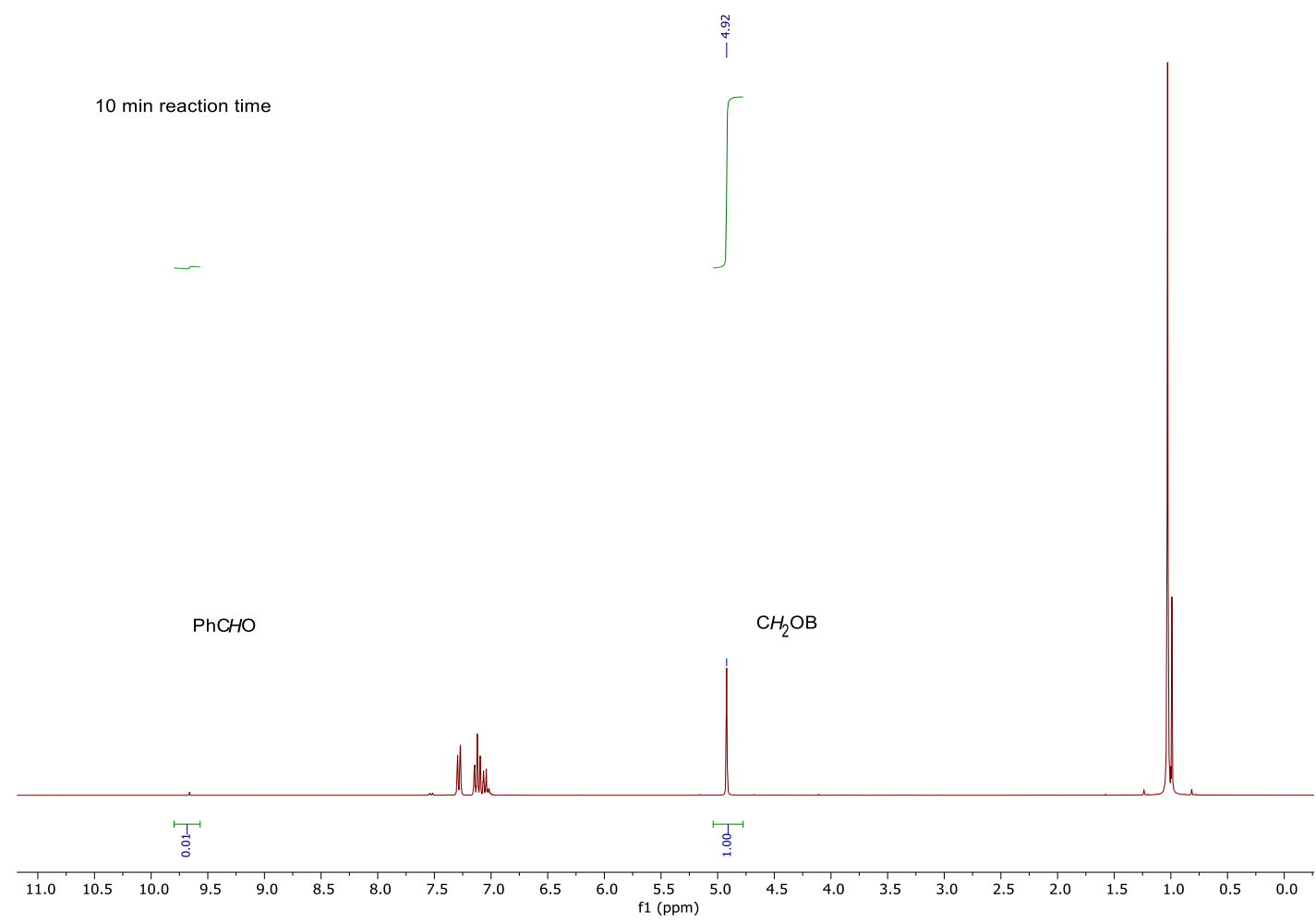

Figure S32. ${ }^{1} \mathrm{H}$ NMR spectrum of the benzaldehyde reduction $(0.1 \mathrm{~mol} \%$ of $\mathbf{2}, 10 \mathrm{~min})$. 


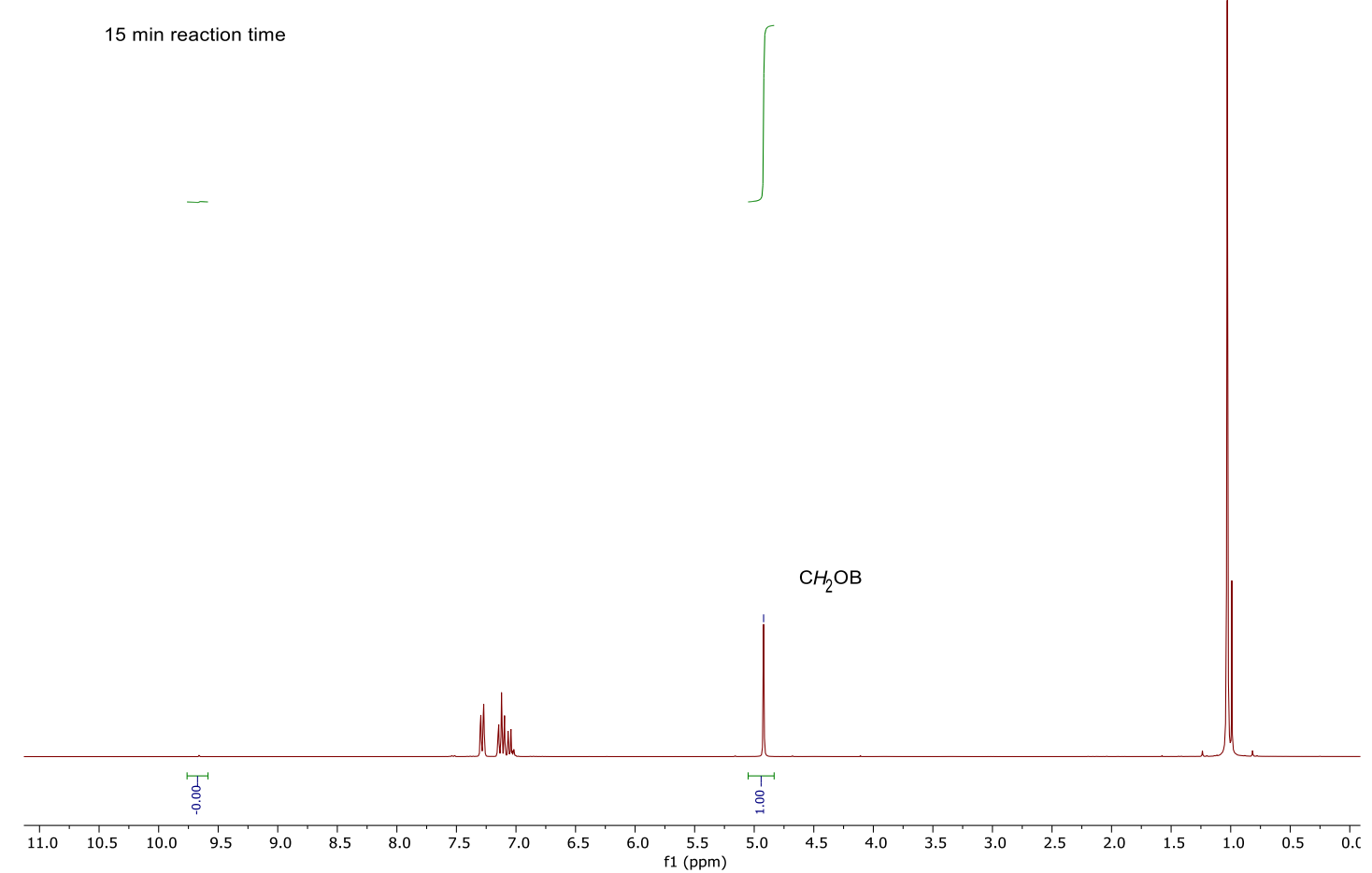

Figure S33. ${ }^{1} \mathrm{H}$ NMR spectrum of the benzaldehyde reduction $(0.1 \mathrm{~mol} \%$ of $2,15 \mathrm{~min})$.

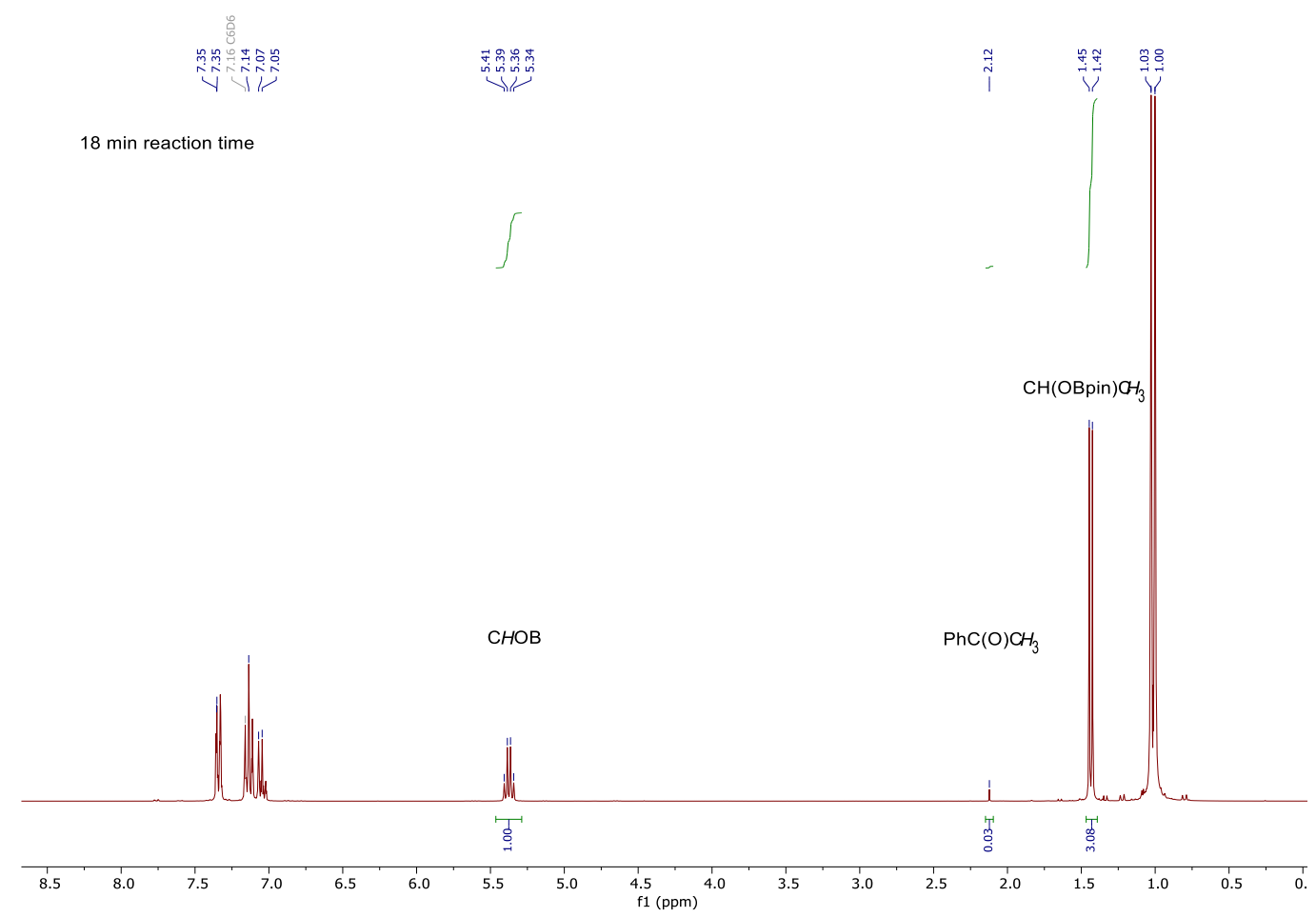

Figure S34. ${ }^{1} \mathrm{H}$ NMR spectrum of the acetophenone reduction $(0.05 \mathrm{~mol} \%$ of $\mathbf{2}, 18 \mathrm{~min})$. 


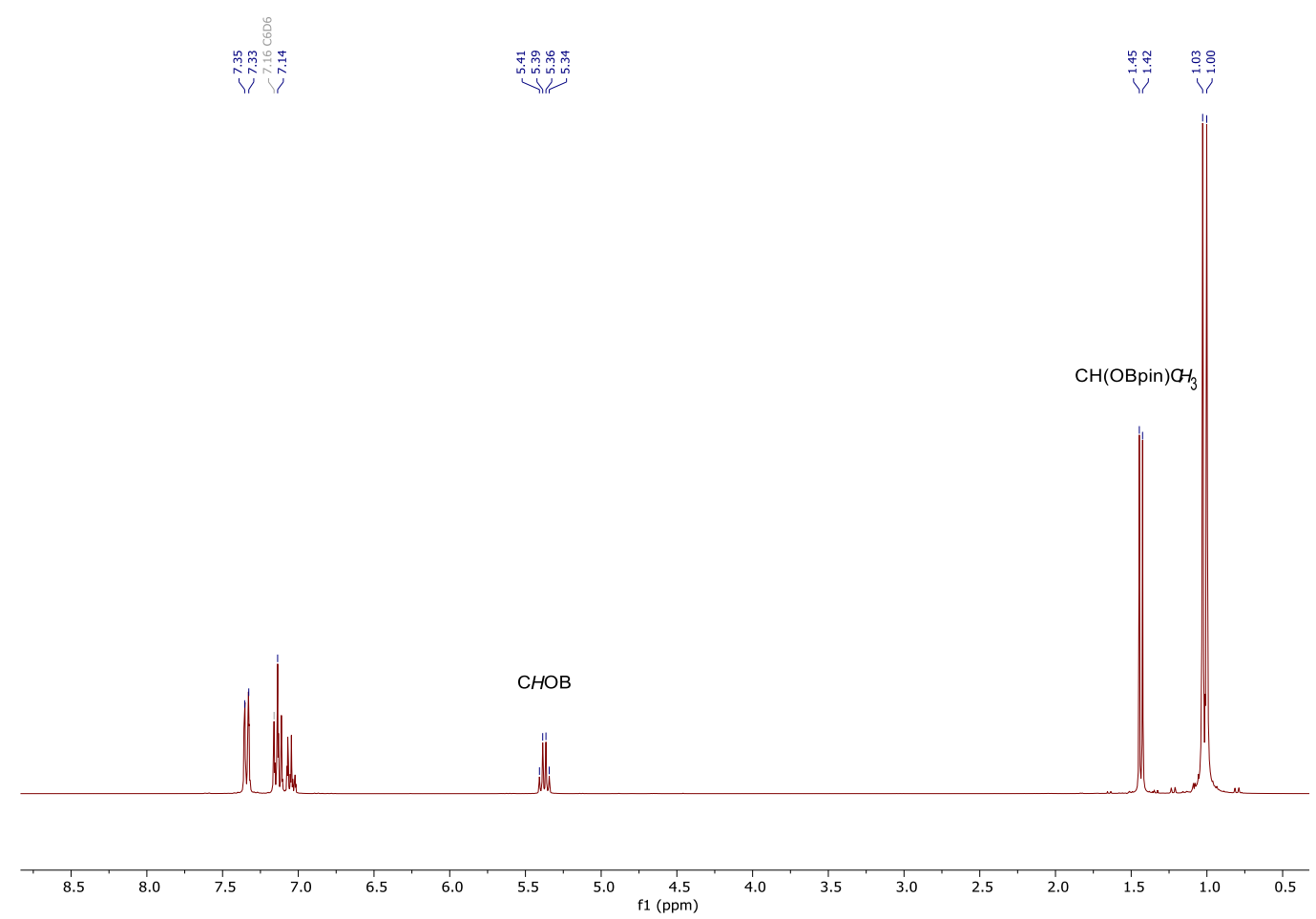

Figure S35. ${ }^{1} \mathrm{H}$ NMR spectrum of the acetophenone reduction $(0.05 \mathrm{~mol} \%$ of $2,28 \mathrm{~min})$.

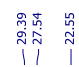

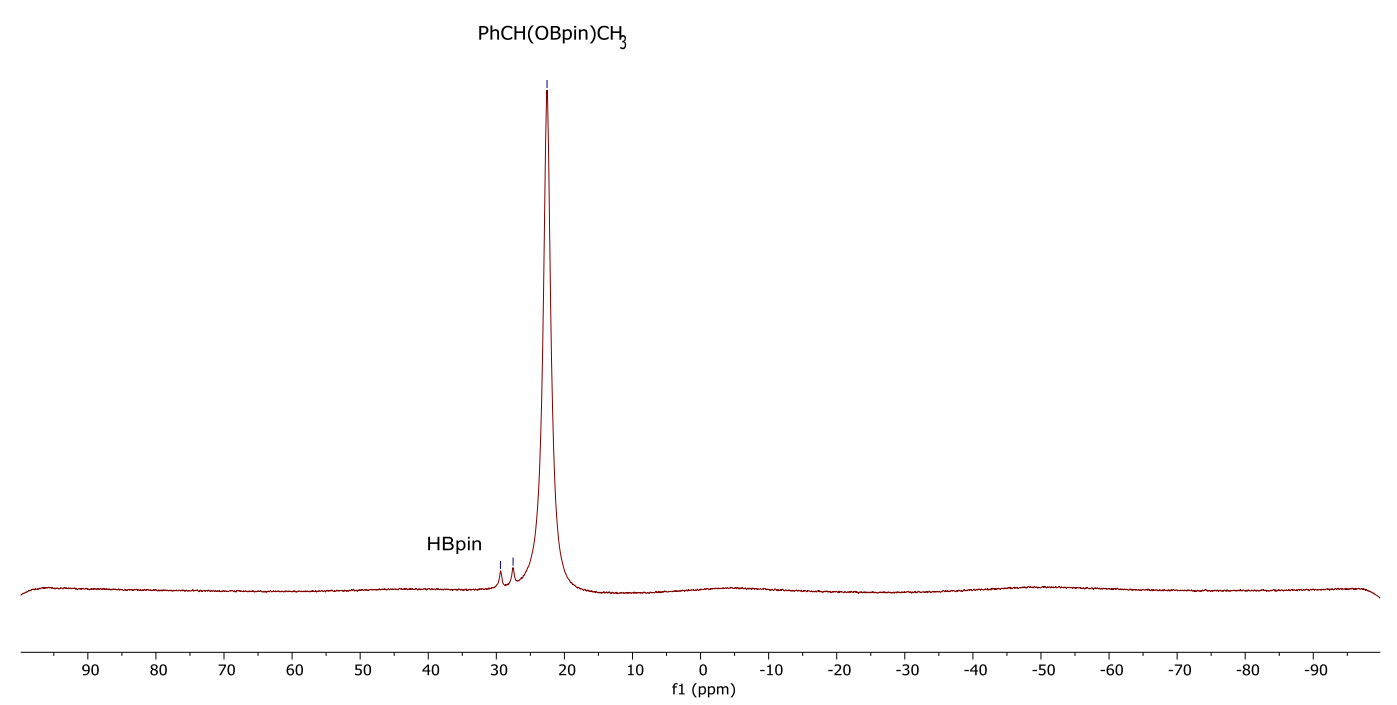

Figure S36. ${ }^{11} \mathrm{~B}$ NMR spectrum of the acetophenone reduction $(0.05 \mathrm{~mol} \%$ of $2,28 \mathrm{~min})$. 


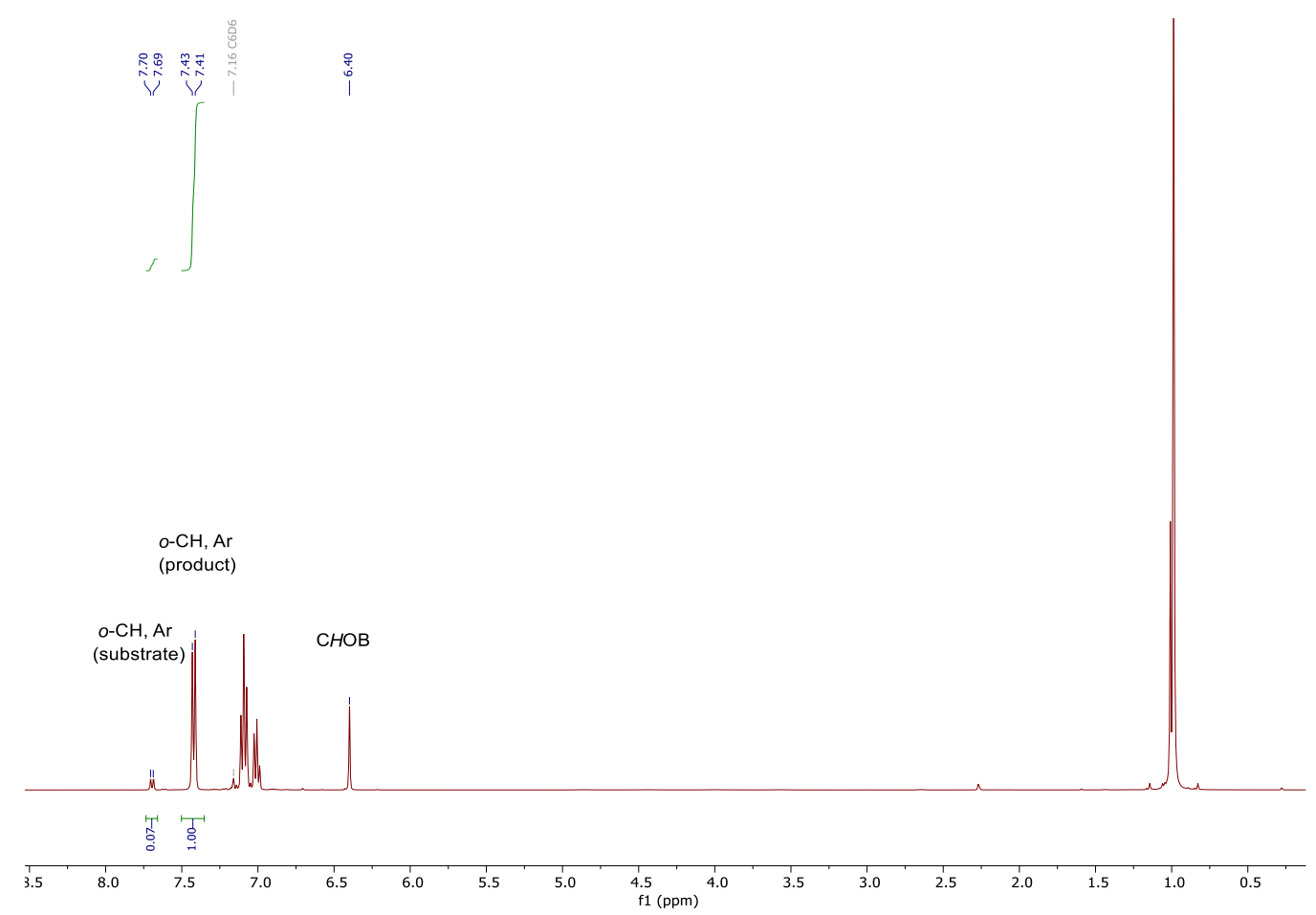

Figure S37. ${ }^{1} \mathrm{H}$ NMR spectrum of the benzophenone reduction $(0.5 \mathrm{~mol} \%$ of $2,1 \mathrm{~h} 35 \mathrm{~min})$.

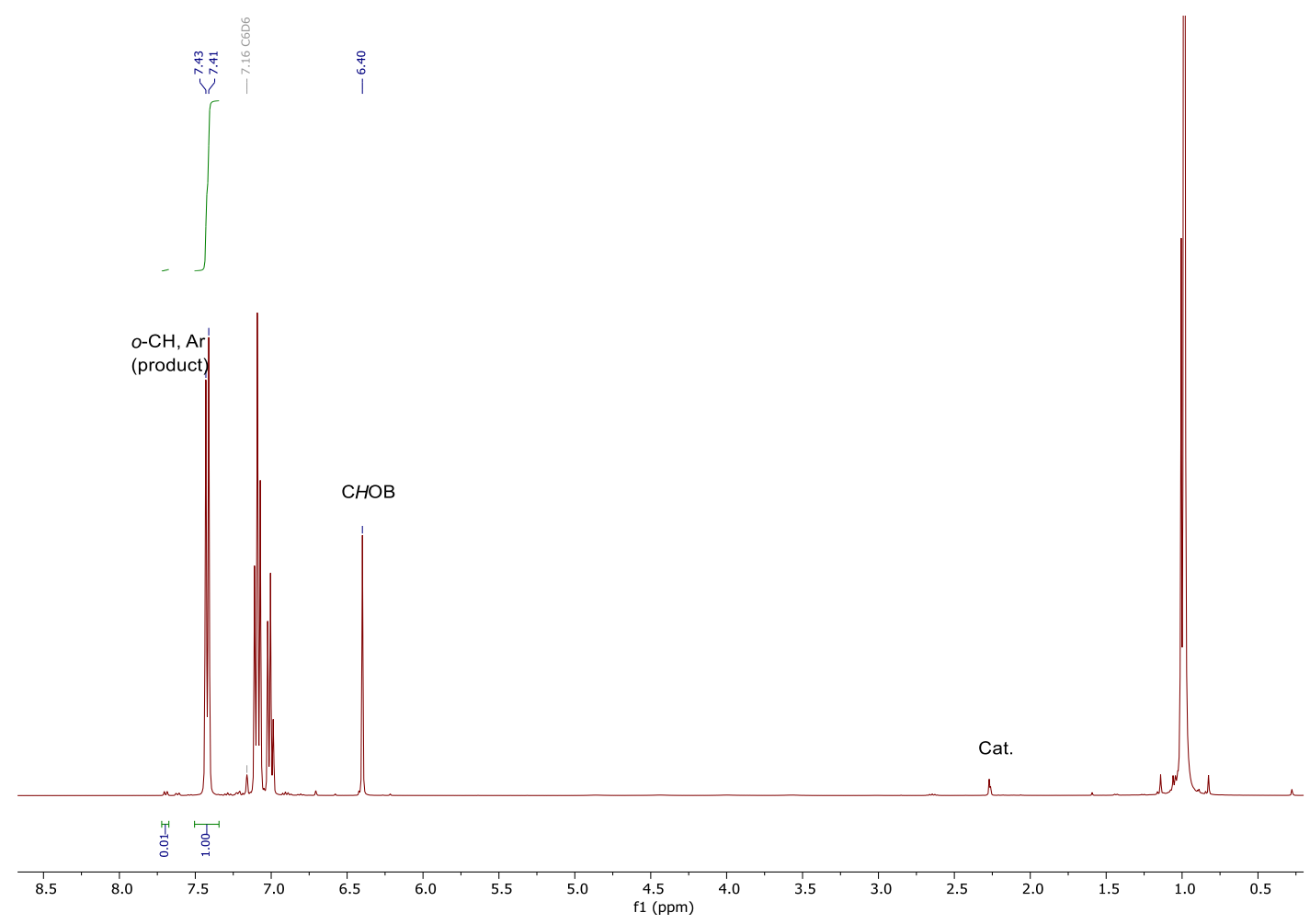

Figure S38. ${ }^{1} \mathrm{H}$ NMR spectrum of the benzophenone reduction $(0.5 \mathrm{~mol} \%$ of 2 , $2 \mathrm{~h} 24 \mathrm{~min})$. 


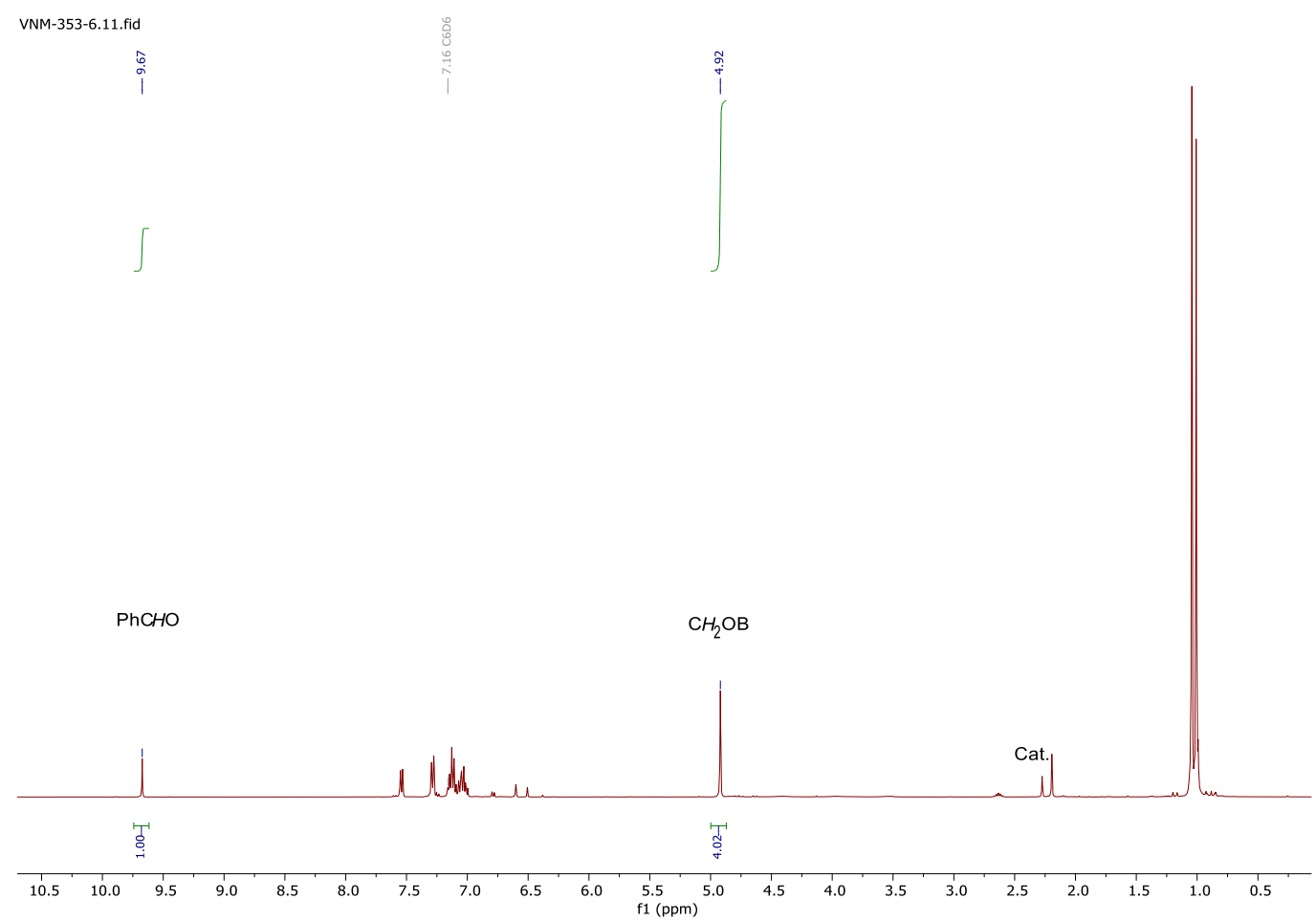

Figure S39. ${ }^{1} \mathrm{H}$ NMR spectrum of the benzaldehyde reduction (4 mol \% of $1,3 \mathrm{~h}$ ).

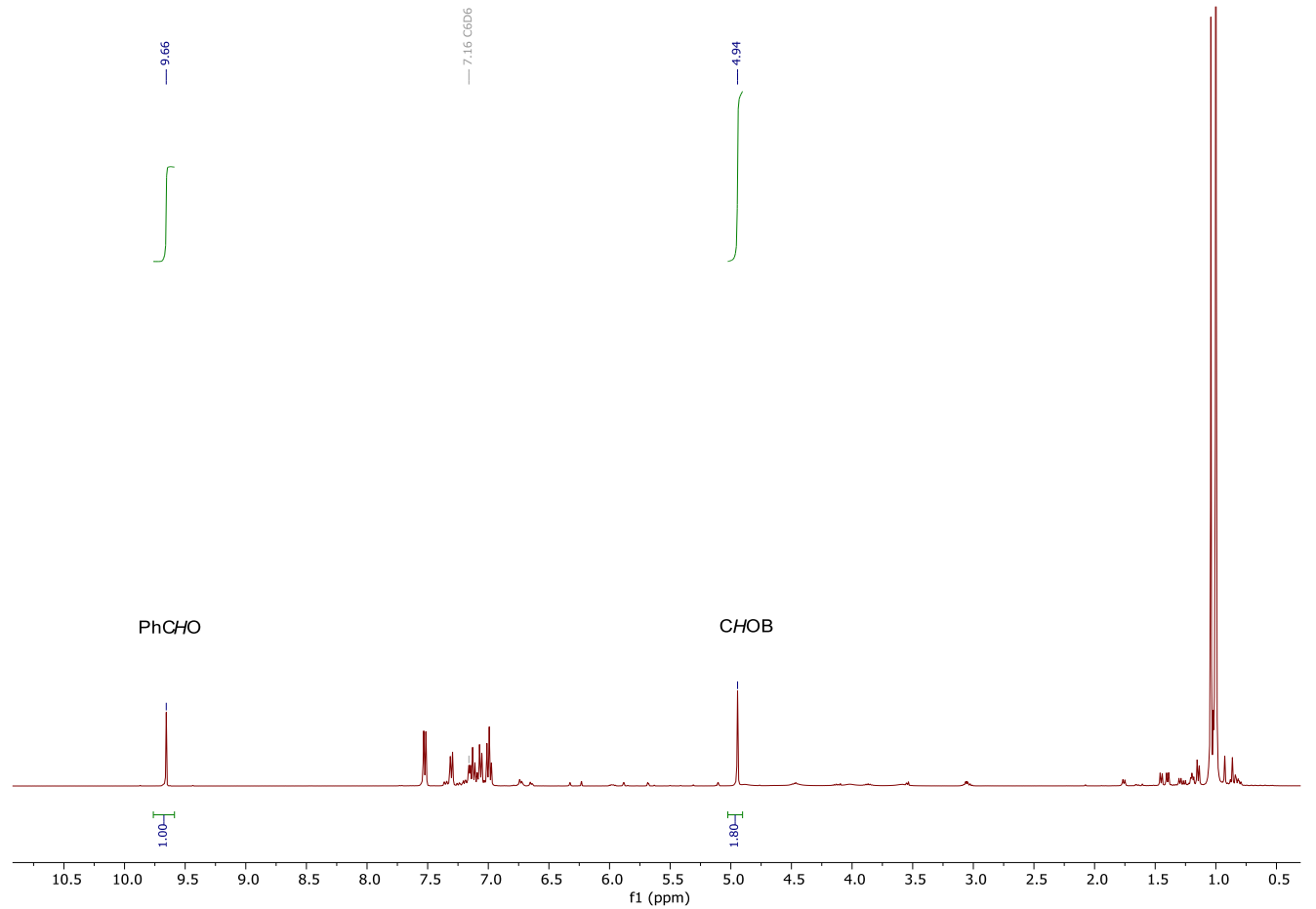

Figure S40. ${ }^{1} \mathrm{H}$ NMR spectrum of the benzaldehyde reduction (4 mol \% of (IDipp)PH, 3h). 


\section{X-Ray Crystallographic data}

\section{General Information}

The X-ray intensity data were collected on an X-ray single crystal diffractometer equipped with a CMOS detector (Bruker Photon-100), a rotating anode (Bruker TXS) with MoK $\alpha$ radiation $(\lambda=0.71073 \AA$ ) and a Helios mirror optic by using the APEX III software package ${ }^{\mathrm{S} 1}$ or an X-ray single crystal diffractometer equipped with a CMOS detector (Bruker Photon-100), an IMS microsource with MoKa radiation $(\lambda=0.71073 \AA)$ and a Helios mirror optic by using the APEX III software package. ${ }^{\mathrm{S} 1}$ The measurement was performed on single crystals coated with perfluorinated ether. The crystal was fixed on the top of a microsampler, transferred to the diffractometer and frozen under a stream of cold nitrogen. A matrix scan was used to determine the initial lattice parameters. Reflections were merged and corrected for Lorenz and polarization effects, scan speed, and background using SAINT. ${ }^{\text {S2 }}$ Absorption corrections, including odd and even ordered spherical harmonics were performed using SADABS. ${ }^{\text {S2 }}$ Space group assignments were based upon systematic absences, E statistics, and successful refinement of the structures. Structures were solved by direct methods with the aid of successive difference Fourier maps, and were refined against all data using the APEX III software ${ }^{\mathrm{S} 1}$ in conjunction with SHELXL-2014 ${ }^{\text {S3 }}$ and SHELXLE. ${ }^{\mathrm{S} 4}$ Methyl hydrogen atoms were refined as part of rigid rotating groups, with a $\mathrm{C}-\mathrm{H}$ distance of $0.98 \AA$ and $\operatorname{Uiso}(\mathrm{H})=1.5 \cdot \operatorname{Ueq}(\mathrm{C})$. Other $\mathrm{H}$ atoms were placed in calculated positions and refined using a riding model, with methylene and aromatic $\mathrm{C}-\mathrm{H}$ distances of 0.99 and $0.95 \AA$, respectively, and $\operatorname{Uiso}(H)=1.2 \cdot \operatorname{Ueq}(C)$. If not mentioned otherwise, non-hydrogen atoms were refined with anisotropic displacement parameters. Full-matrix least-squares refinements were carried out by minimizing $\Delta \mathrm{w}(\mathrm{Fo} 2-\mathrm{Fc} 2) 2$ with SHELXL-97 ${ }^{\mathrm{S} 5}$ weighting scheme. Neutral atom scattering factors for all atoms and anomalous dispersion corrections for the non-hydrogen atoms were taken from International Tables for Crystallography. ${ }^{\mathrm{S} 6}$ Images of the crystal structures were generated by PLATON. ${ }^{\text {S7 }}$ 


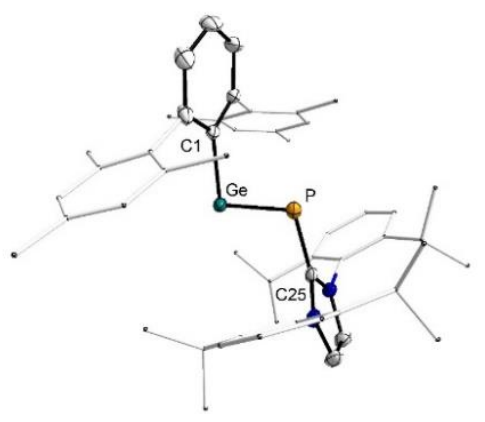

Selected bond lengths $[\AA]$ and bond angles $\left[{ }^{\circ}\right]$ : Ge-P: 2.2364(5), C1-Ge: 2.026(2), P-C25: 1.8055(21), C1-Ge-P: 89.56(5), Ge-P-C25: 101.76(6).

Table S1. Data collection and structure refinement for $\mathbf{1}$.

\begin{tabular}{|c|c|}
\hline Compound & 1 \\
\hline Chemical formula & $\mathrm{C}_{51} \mathrm{H}_{61} \mathrm{GeN}_{2} \mathrm{P}$ \\
\hline Formula weight & 805.60 \\
\hline Radiation source & TXS rotating anode, $\mathrm{MoK}$ \\
\hline Temperature $(\mathrm{K})$ & 100 \\
\hline Wavelength $(\AA)$ & 0.71073 \\
\hline Crystal size $(\mathrm{mm})$ & $0.11 \times 0.10 \times 0.07$ \\
\hline Crystal system (Space group) & Triclinic, $P-1$ \\
\hline Unit cell dimensions & $\begin{array}{l}\mathrm{a}=11.7911(7) \AA, \alpha=71.993(3)^{\circ} \\
\mathrm{b}=12.4317(8) \AA, \beta=89.507(3)^{\circ} \\
\mathrm{c}=16.8301(11) \AA ; \gamma=71.525(2)^{\circ}\end{array}$ \\
\hline Volume $\left(\AA^{3}\right)$ & $2214.3(2)$ \\
\hline $\mathrm{Z}$ & 2 \\
\hline Density $\mathrm{D}_{\mathrm{x}}\left(\mathrm{g} / \mathrm{cm}^{3}\right)$ & 1.208 \\
\hline Absorption coefficient $\mu\left(\mathrm{mm}^{-1}\right)$ & 0.764 \\
\hline Absorption correction & multi-scan \\
\hline $\mathrm{F}(000)$ & 856 \\
\hline Theta range for data collection $\left(^{\circ}\right)$ & 2.3 to 25.4 \\
\hline Index ranges & $-14<=\mathrm{h}<=14,-14<=\mathrm{k}<=14,-20<=\mathrm{l}<=20$ \\
\hline Reflections collected & 7209 with $\mathrm{I}>2 \sigma(I), R_{\text {int }}=0.043$ \\
\hline Independent reflections & 8088 \\
\hline Coverage of independent reflections (\%) & 99.9 \\
\hline Refinement method & full-matrix least-squares on $\mathrm{F}^{2}$ \\
\hline Data / restraints / parameters & $8088 / 75 / 540$ \\
\hline Goodness-of-fit on $\mathrm{F}^{2}$ & 1.024 \\
\hline Final $R$ indices $(I>2 \sigma(I))$ & $\mathrm{R} 1=0.0278, \mathrm{wR} 2=0.0685$ \\
\hline
\end{tabular}




\begin{tabular}{|l|l|}
\hline $\mathrm{R}$ indices (all data) & $\mathrm{R} 1=0.0340, \mathrm{wR} 2=0.0717$ \\
\hline Largest diff. peak and hole $\left(\mathrm{e} \AA^{-3}\right)$ & 0.326 and -0.366 \\
\hline
\end{tabular}

Stannylene-phosphinidene complex 2 (CCDC 1946725)

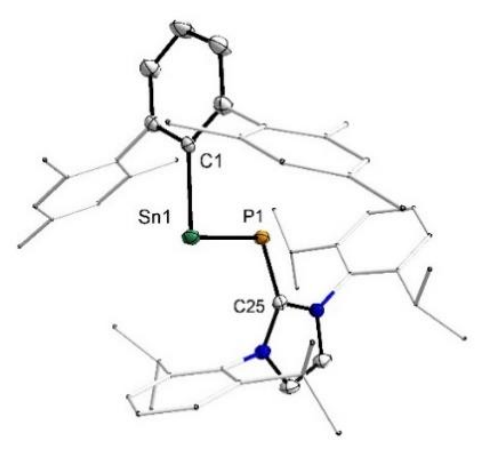

Selected bond lengths $[\AA]$ and bond angles $\left[{ }^{\circ}\right]$ : Sn-P: 2.4562(7), C1-Sn: 2.230(2), P-C25: 1.784(2), C1-Sn-P: 86.69(6), Sn-P-C25: 109.20(7).

Table S2. Data collection and structure refinement for $\mathbf{2}$.

\begin{tabular}{|l|l|}
\hline Compound & $\mathbf{2}$ \\
\hline Chemical formula & $\mathrm{C}_{51} \mathrm{H}_{61} \mathrm{~N}_{2} \mathrm{PSn}$ \\
\hline Formula weight & 851.70 \\
\hline Radiation source & TXS rotating anode, Mo \\
\hline Temperature $(\mathrm{K})$ & 100 \\
\hline Wavelength $(\AA)$ & 0.71073 \\
\hline Crystal size $(\mathrm{mm})$ & $0.22 \times 0.17 \times 0.12$ \\
\hline Crystal system $($ Space group) & Monoclinic, $P 2_{1} / c$ \\
\hline Unit cell dimensions & $\mathrm{a}=23.238(6) \AA, \alpha=90^{\circ}$ \\
& $\mathrm{b}=19.937(5) \AA, \beta=115.890(11)^{\circ}$ \\
& $\mathrm{c}=22.444(6) \AA ; \gamma=90^{\circ}$ \\
\hline Volume $\left(\AA^{3}\right)$ & 9355 \\
\hline$Z$ & 8 \\
\hline Density $D_{x}\left(\mathrm{~g} / \mathrm{cm}^{3}\right)$ & 1.209 \\
\hline Absorption coefficient $\mu\left(\mathrm{mm}^{-1}\right)$ & 0.614 \\
\hline Absorption correction & multi-scan \\
\hline F $(000)$ & 3568 \\
\hline Theta range for data collection $\left(^{\circ}\right)$ & 2.04 to 25.03 \\
\hline Index ranges & $-27<=\mathrm{h}<=27,-23<=\mathrm{k}<=23,-26<=1<=26$ \\
\hline Reflections collected & 13975 with $\mathrm{I}>2 \sigma(I), R_{\text {int }}=0.059$ \\
\hline Independent reflections & 16527 \\
\hline
\end{tabular}




\begin{tabular}{|l|l|}
\hline Coverage of independent reflections (\%) & 99.9 \\
\hline Refinement method & full-matrix least-squares on $\mathrm{F}^{2}$ \\
\hline Data / restraints / parameters & $16527 / 0 / 1019$ \\
\hline Goodness-of-fit on $\mathrm{F}^{2}$ & 1.038 \\
\hline Final R indices (I>2 $\sigma(\mathrm{I}))$ & $\mathrm{R} 1=0.0279, \mathrm{wR} 2=0.0615$ \\
\hline $\mathrm{R}$ indices (all data) & $\mathrm{R} 1=0.0388, \mathrm{wR} 2=0.0658$ \\
\hline Largest diff. peak and hole $\left(\mathrm{e} \AA^{-3}\right)$ & 0.366 and -0.424 \\
\hline
\end{tabular}

Heterocycle 3 (CCDC 1946726)

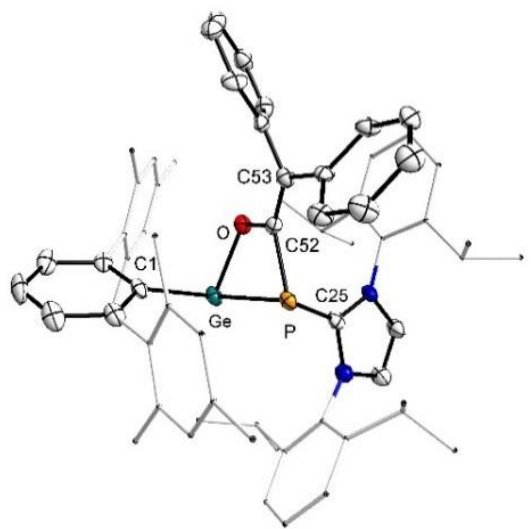

Selected bond lengths $[\AA]$ and bond angles $\left[{ }^{\circ}\right]$ : Ge-P: 2.5319(14), Ge-O: 1.946(4), C1-Ge: 2.055(4), P-C52: 1.877(5), P-C25: 1.836(6), C52-O: 1.343(6), C52-C53: 1.352(7), O-Ge-P: 71.28(11), Ge-PC52: 71.63(14), Ge-O-C52: 104.9(3), P-C52-O: 109.8(3), C1-Ge-P: 106.16(13), Ge-P-C25: 90.24(16).

Table S3. Data collection and structure refinement for $\mathbf{3}$.

\begin{tabular}{|l|l|}
\hline Compound & $\mathbf{3}$ \\
\hline Chemical formula & $\mathrm{C}_{65} \mathrm{H}_{71} \mathrm{GeN}_{2} \mathrm{OP}$ \\
\hline Formula weight & 999.82 \\
\hline Radiation source & $\mathrm{IMS}$ microsource, Mo \\
\hline Temperature (K) & 100 \\
\hline Wavelength $(\AA)$ & 0.71073 \\
\hline Crystal size (mm) & $0.31 \times 0.22 \times 0.21$ \\
\hline Crystal system (Space group) & Monoclinic, $P 2_{1} / n$ \\
\hline Unit cell dimensions & $\mathrm{a}=11.4348(9) \AA, \alpha=90^{\circ}$ \\
& $\mathrm{b}=25.036(2) \AA, \beta=98.151(3)^{\circ}$ \\
$\mathrm{c}=20.8663(16) \AA ; \gamma=90^{\circ}$
\end{tabular}




\begin{tabular}{|l|l|}
\hline $\mathrm{Z}$ & 4 \\
\hline Density $\mathrm{D}_{\mathrm{x}}\left(\mathrm{g} / \mathrm{cm}^{3}\right)$ & 1.123 \\
\hline Absorption coefficient $\mu\left(\mathrm{mm}^{-1}\right)$ & 0.585 \\
\hline Absorption correction & multi-scan \\
\hline $\mathrm{F}(000)$ & 2120 \\
\hline Theta range for data collection $\left(^{\circ}\right)$ & 2.17 to 25.47 \\
\hline Index ranges & $-13<=\mathrm{h}<=13,-30<=\mathrm{k}<=30,-24<=1<=25$ \\
\hline Reflections collected & 9730 with $\mathrm{I}>2 \sigma(I), R_{\text {int }}=0.068$ \\
\hline Independent reflections & 10788 \\
\hline Coverage of independent reflections $(\%)$ & 99.6 \\
\hline Refinement method & full-matrix least-squares on $\mathrm{F}^{2}$ \\
\hline Data / restraints / parameters & $10788 / 300 / 763$ \\
\hline Goodness-of-fit on $\mathrm{F}^{2}$ & 1.202 \\
\hline Final $\mathrm{R}$ indices $(\mathrm{I}>2 \sigma(\mathrm{I}))$ & $\mathrm{R} 1=0.0904, \mathrm{wR} 2=0.1991$ \\
\hline $\mathrm{R}$ indices (all data) & $\mathrm{R} 1=0.0978, \mathrm{wR} 2=0.2024$ \\
\hline Largest diff. peak and hole $\left(\mathrm{e} \AA^{-3}\right)$ & 2.048 and -1.135 \\
\hline
\end{tabular}

\section{Heterocycle 4 (CCDC 1946727)}

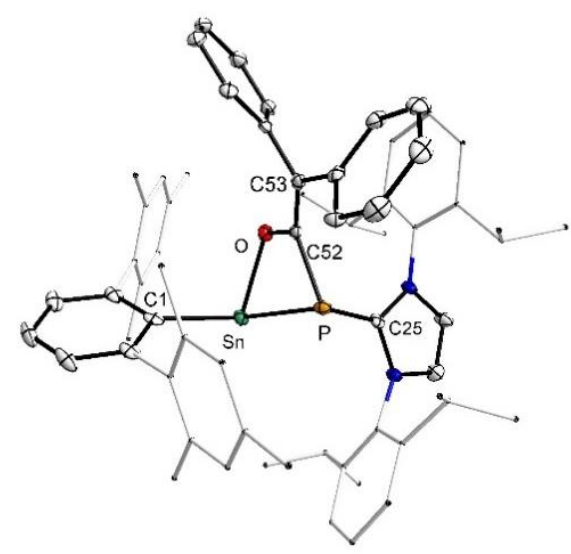

Selected bond lengths $[\AA]$ and bond angles $\left[{ }^{\circ}\right]$ : Sn-P: 2.7299(10), Sn-O: 2.126(2), C1-Sn: 2.242(3), PC52: 1.874(3), P-C25: 1.830(3), C52-O: 1.342(4), C52-C53: 1.356(5), O-Sn-P: 65.74(6), Sn-P-C52: 72.72(11), Sn-O-C52: 106.32(18), P-C52-O: 112.1(2), C1-Sn-P: 105.39(9), Sn-P-C25: 89.91(11).

Table S4. Data collection and structure refinement for 4.

\begin{tabular}{|l|l|}
\hline Compound & $\mathbf{4}$ \\
\hline Chemical formula & $\mathrm{C}_{65} \mathrm{H}_{71} \mathrm{~N}_{2} \mathrm{OPSn}$ \\
\hline Formula weight & 1045.92 \\
\hline
\end{tabular}




\begin{tabular}{|c|c|}
\hline Radiation source & IMS microsource, Mo \\
\hline Temperature $(\mathrm{K})$ & 100 \\
\hline Wavelength $(\AA)$ & 0.71073 \\
\hline Crystal size $(\mathrm{mm})$ & $0.25 \times 0.23 \times 0.08$ \\
\hline Crystal system (Space group) & Monoclinic, $P 2_{1} / n$ \\
\hline Unit cell dimensions & $\begin{array}{l}a=11.3462(6) \AA, \alpha=90^{\circ} \\
b=24.7253(12) \AA, \beta=98.711(2)^{\circ} \\
c=21.5162(11) \AA ; \gamma=90^{\circ}\end{array}$ \\
\hline Volume $\left(\AA^{3}\right)$ & $5966.5(5)$ \\
\hline $\mathrm{Z}$ & 4 \\
\hline Density $D_{x}\left(\mathrm{~g} / \mathrm{cm}^{3}\right)$ & 1.164 \\
\hline Absorption coefficient $\mu\left(\mathrm{mm}^{-1}\right)$ & 0.495 \\
\hline Absorption correction & multi-scan \\
\hline $\mathrm{F}(000)$ & 2192 \\
\hline Theta range for data collection $\left(^{\circ}\right)$ & 2.3 to 25.4 \\
\hline Index ranges & $-13<=\mathrm{h}<=13,-29<=\mathrm{k}<=29,-25<=1<=25$ \\
\hline Reflections collected & 8966 with $\mathrm{I}>2 \sigma(I), R_{\mathrm{int}}=0.0757$ \\
\hline Independent reflections & 10923 \\
\hline Coverage of independent reflections (\%) & 99.9 \\
\hline Refinement method & full-matrix least-squares on $\mathrm{F}^{2}$ \\
\hline Data / restraints / parameters & $10923 / 0$ / 645 \\
\hline Goodness-of-fit on $\mathrm{F}^{2}$ & 1.047 \\
\hline Final R indices $(\mathrm{I}>2 \sigma(\mathrm{I}))$ & $\mathrm{R} 1=0.0472, \mathrm{wR} 2=0.0943$ \\
\hline $\mathrm{R}$ indices (all data) & $\mathrm{R} 1=0.0641, \mathrm{wR} 2=0.1003$ \\
\hline Largest diff. peak and hole $\left(e \AA^{-3}\right)$ & 2.953 and -1.493 \\
\hline
\end{tabular}




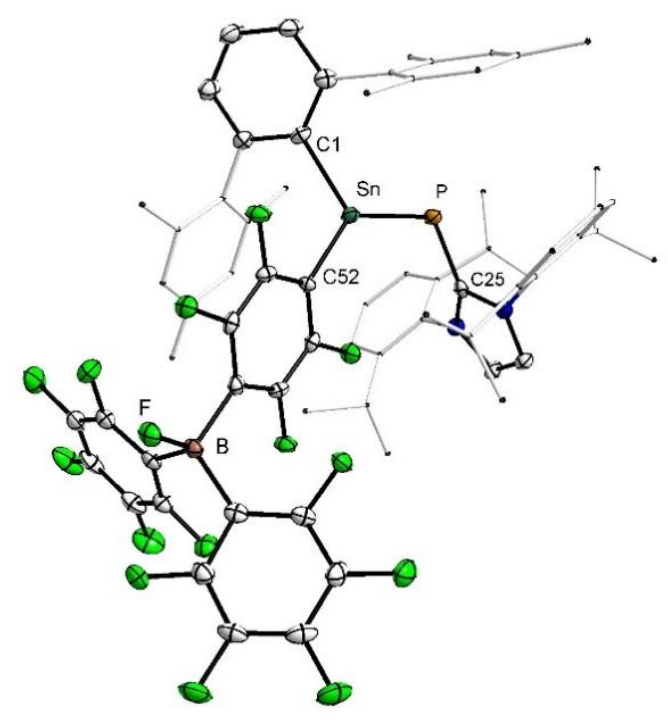

Selected bond lengths $[\AA]$ and bond angles $\left[{ }^{\circ}\right]$ : Sn-P: 2.3450(10), Sn-C1: 2.124(3), Sn-C1: 2.124(3), P-C25: 1.816(3), B-F: 1.418(4), C1-Sn-P: 115.72(10), C1-Sn-C52: 112.31(12), C52-Sn-P: 131.86(8), Sn-P-C25: 106.10(11).

Table S5. Data collection and structure refinement for $\mathbf{5}$.

\begin{tabular}{|l|l|}
\hline Compound & $\mathbf{5}$ \\
\hline Chemical formula & $\mathrm{C}_{69} \mathrm{H}_{61} \mathrm{BF}_{15} \mathrm{~N}_{2} \mathrm{PSn} \cdot 2\left(\mathrm{C}_{6} \mathrm{H}_{6}\right)$ \\
\hline Formula weight & 1519.91 \\
\hline Radiation source & IMS microsource, $\mathrm{Mo}$ \\
\hline Temperature $(\mathrm{K})$ & 100 \\
\hline Wavelength $(\AA)$ & 0.71073 \\
\hline Crystal size $(\mathrm{mm})$ & $0.17 \times 0.14 \times 0.11$ \\
\hline Crystal system $($ Space group $)$ & Triclinic, $P_{1}$ \\
\hline Unit cell dimensions & $\mathrm{a}=15.8715(6) \AA, \alpha=95.537(1)^{\circ}$ \\
& $\mathrm{b}=16.0610(5) \AA, \beta=117.541(1)^{\circ}$ \\
& $\mathrm{c}=16.3836(5) \AA ; \gamma=99.354(1)^{\circ}$ \\
\hline Volume $\left(\AA^{3}\right)$ & $3582.9(2)$ \\
\hline $\mathrm{Z}$ & 2 \\
\hline Density $\mathrm{D}_{\mathrm{x}}\left(\mathrm{g} / \mathrm{cm}^{3}\right)$ & 1.409 \\
\hline Absorption coefficient $\mu\left(\mathrm{mm}^{-1}\right)$ & 0.464 \\
\hline Absorption correction & multi-scan \\
\hline $\mathrm{F}(000)$ & 1556 \\
\hline Theta range for data collection $\left({ }^{\circ}\right)$ & 2.5 to 25.3 \\
\hline Index ranges & $-19<=\mathrm{h}<=19,-19<=\mathrm{k}<=19,-19<=1<=19$ \\
\hline
\end{tabular}




\begin{tabular}{|l|l|}
\hline Reflections collected & 11425 with $\mathrm{I}>2 \sigma(I), R_{\text {int }}=0.058$ \\
\hline Independent reflections & 13090 \\
\hline Coverage of independent reflections $(\%)$ & 99.9 \\
\hline Refinement method & full-matrix least-squares on $\mathrm{F}^{2}$ \\
\hline Data / restraints / parameters & $13090 / 0 / 924$ \\
\hline Goodness-of-fit on $\mathrm{F}^{2}$ & 1.049 \\
\hline Final R indices $(\mathrm{I}>2 \sigma(\mathrm{I}))$ & $\mathrm{R} 1=0.0396, \mathrm{wR} 2=0.0810$ \\
\hline R indices (all data) & $\mathrm{R} 1=0.0483, \mathrm{wR} 2=0.0858$ \\
\hline Largest diff. peak and hole $\left(\mathrm{e}^{-3}\right)$ & 3.212 and -1.607 \\
\hline
\end{tabular}




\section{Computational Details}

DFT calculations were performed with the ORCA program. ${ }^{\mathrm{S} 8}$ All geometry optimizations were run in redundant internal coordinates with tight convergence criteria in the gas-phase, using the B3LYP functional $^{\mathrm{S9}}$ together with the def2-TZVP basis set. ${ }^{\mathrm{S} 10}$ Effective core potential (ECP) was used for Sn atoms $[\mathrm{SD}(28, \mathrm{MDF})] .{ }^{\mathrm{S} 11}$ The latest Grimme's semiempirical atom-pair-wise London dispersion correction (DFT-D3) was included in all calculations. ${ }^{\text {S12 }}$ Harmonic frequency calculations verified the nature of ground states or transition states (TS) having all positive frequencies or only one imaginary frequency, respectively. From these optimized geometries all reported data were obtained by means of single-point (SP) calculations using the more polarized def2-TZVPP basis set. ${ }^{\mathrm{S} 13}$ Reported energies were corrected for the zero-point vibrational term at the optimization level. Final energies were obtained by means of the recently developed near linear scaling domain-based local pair natural orbital (DLPNO) method $^{\mathrm{S} 14}$ to achieve coupled cluster theory with single-double and perturbative triple excitations $(\mathrm{CCSD}(\mathrm{T})) .{ }^{\mathrm{S} 15}$ In case of open-shell systems, local correlation schemes of type LPNO (Local Pair Natural Orbital) for high level single reference methods, such as CEPA (Coupled Electron-Pair Approximation), ${ }^{\mathrm{S} 16}$ here the slightly modified NCEPA/1 version ${ }^{\mathrm{S} 17}$ implemented in ORCA, was used. The topological analysis of the electron density $\rho(r)$ was performed with Multiwfn. ${ }^{\mathrm{S} 18}$

\section{Model Compounds used in Calculations}

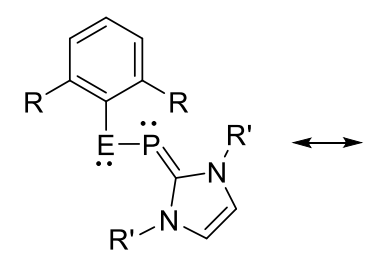

A

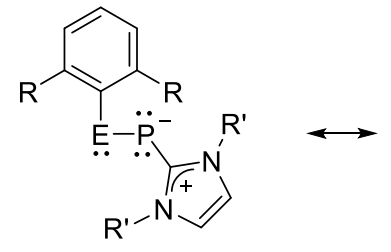

B

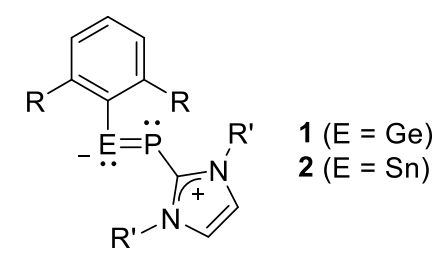

C

\begin{tabular}{lll}
\hline Compd. & $\mathrm{R}$ & $\mathrm{R}$ \\
\hline 1a and 2a & $\mathrm{Xyl}$ & $2,6-\mathrm{Mes}_{2} \mathrm{Ph}$ \\
1b and 2b & $\mathrm{Me}$ & $\mathrm{Xyl}$ \\
$\mathbf{1 c}$ and 2c & $\mathrm{Me}$ & $\mathrm{Me}$ \\
\hline
\end{tabular}

$\mathrm{Xyl}=2,6-\left(\mathrm{CH}_{3}\right)_{2} \mathrm{C}_{6} \mathrm{H}_{3} ; \mathrm{Mes}=2,4,6-\left(\mathrm{CH}_{3}\right)_{3} \mathrm{C}_{6} \mathrm{H}_{2}$ 


\section{Bond Strength Parameters and Natural Charges}

Lewis structural formulae were drawn according to the best electronic description, as deduced from standard bond-strength descriptors, natural charges (Table S6), and NBO (natural bond orbital) analysis. ${ }^{\mathrm{S} 19}$ Representative bond-strength related parameters were computed for the $\mathrm{C}-\mathrm{P}$ and $\mathrm{P}-\mathrm{E}(\mathrm{E}=$ $\mathrm{Sn}, \mathrm{Ge}$ ) bonds. They include the bond distance, two representative and wide-spread used bond indices, such as the Wiberg bond index (WBI) ${ }^{\mathrm{S} 20}$ and the Mayer bond order (MBO), ${ }^{\mathrm{S} 21}$ as well as properties derived from the topological analysis of the electron density, in line with Bader's AIM (atoms-inmolecules) theory, ${ }^{\text {S22 }}$ in particular the electron density itself $(\rho)$ and the Lagrangian kinetic energy $(G)$ computed at the bond critical point (BCP). The latter was only recently used for characterizing bond strength in phosphorus-containing three-membered heterocycles ${ }^{\mathrm{S} 23}$ and, soon afterwards, the Lagrangian kinetic energy density per electron $(G / \rho)$ was reported as a remarkable bond-strength property ${ }^{\mathrm{S} 24}$ which correlates with ring strain energies (within a series) when computed at the ring critical points. ${ }^{\text {S25 }}$ Also the compliance matrix method ${ }^{\mathrm{S} 26}$ allows obtaining the relaxed force constants $k^{0}$, which have received much attention in recent years as a measure of bond stiffness in a variety of bonding situations ${ }^{\mathrm{S} 27}$ including organophosphorus derivatives. ${ }^{\mathrm{S} 24 \mathrm{~b}, \mathrm{~S} 28}$

Table S6. Endocyclic bond strength parameters and natural charges.

\begin{tabular}{|c|c|c|c|c|c|c|c|c|c|c|}
\hline Compd. & Bond & $d^{[a]}$ & WBI & MBO & $\rho^{[b]}$ & $\mathbf{G} / \rho^{[b]}$ & $\varepsilon$ & $k^{0[\mathrm{cc}]}$ & Group & $\mathbf{q}^{[\mathbf{b}]}$ \\
\hline \multirow[t]{2}{*}{ 1a } & $\mathrm{C}-\mathrm{P}$ & 1.793 & 1.122 & 1.242 & 0.1486 & 1.120 & 0.127 & [d] & NHC & 0.275 \\
\hline & $\mathrm{P}-\mathrm{Ge}$ & 2.260 & 1.300 & 1.419 & 0.0979 & 0.462 & 0.205 & [d] & Ge-R' & -0.011 \\
\hline \multirow[t]{2}{*}{ 1b } & $\mathrm{C}-\mathrm{P}$ & 1.804 & 1.090 & 1.230 & 0.1461 & 1.064 & 0.073 & 2.896 & NHC & 0.314 \\
\hline & $\mathrm{P}-\mathrm{Ge}$ & 2.267 & 1.361 & 1.479 & 0.0960 & 0.466 & 0.220 & 1.866 & Ge-R' & -0.030 \\
\hline \multirow[t]{2}{*}{$1 c$} & $\mathrm{C}-\mathrm{P}$ & 1.800 & 1.107 & 1.248 & 0.1469 & 1.066 & 0.071 & 2.909 & NHC & 0.306 \\
\hline & $\mathrm{P}-\mathrm{Ge}$ & 2.271 & 1.349 & 1.483 & 0.0956 & 0.464 & 0.214 & 1.854 & Ge-R' & 0.015 \\
\hline \multirow[t]{2}{*}{$2 a$} & $\mathrm{C}-\mathrm{P}$ & 1.782 & 1.194 & 1.323 & 0.1504 & 1.150 & 0.139 & [d] & NHC & 0.219 \\
\hline & $\mathrm{P}-\mathrm{Sn}$ & 2.474 & 1.063 & 1.235 & 0.0776 & 0.499 & 0.180 & [d] & Sn-R' & 0.231 \\
\hline \multirow[t]{2}{*}{$2 b$} & $\mathrm{C}-\mathrm{P}$ & 1.799 & 1.118 & 1.215 & 0.1468 & 1.089 & 0.025 & 2.968 & NHC & 0.288 \\
\hline & $\mathrm{P}-\mathrm{Sn}$ & 2.469 & 1.256 & 1.362 & 0.0760 & 0.522 & 0.255 & 1.538 & Sn-R' & 0.090 \\
\hline \multirow[t]{2}{*}{$2 c$} & $\mathrm{C}-\mathrm{P}$ & 1.795 & 1.128 & 1.228 & 0.1476 & 1.082 & 0.044 & 2.986 & NHC & 0.283 \\
\hline & $\mathrm{P}-\mathrm{Sn}$ & 2.472 & 1.264 & 1.357 & 0.0758 & 0.524 & 0.246 & 1.538 & Sn-R' & 0.102 \\
\hline
\end{tabular}

${ }^{[\mathrm{a}]} \mathrm{In} \AA ;{ }^{[\mathrm{b}]}$ in au; ${ }^{[\mathrm{c}]}$ in mdyn/ $\AA ;{ }^{[\mathrm{d}]}$ not computed 


\section{Frontier Molecular Orbitals in Germylene- and Stannylene-Phosphinidene NHC}

\section{Complexes 1a and 2a}

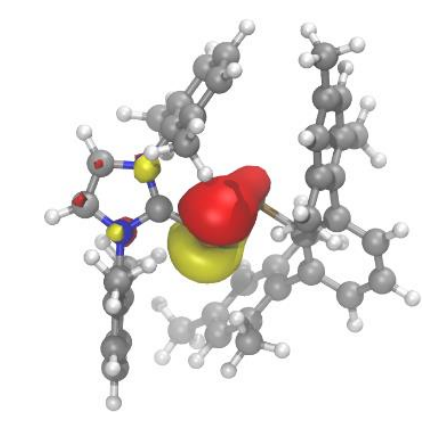

HOMO-1 $(-4.883 \mathrm{eV})$

$\pi(\mathrm{Ge}=\mathrm{P})$ largely located at $\mathrm{P}$

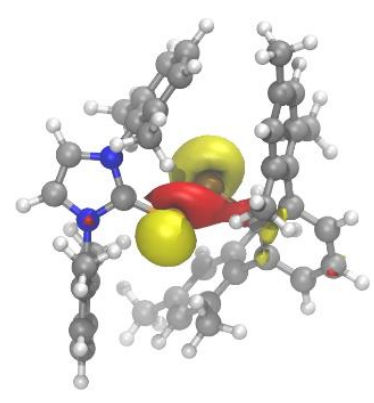

$\operatorname{HOMO}(-4.694 \mathrm{eV})$ $\sigma(\mathrm{Ge}-\mathrm{P})$

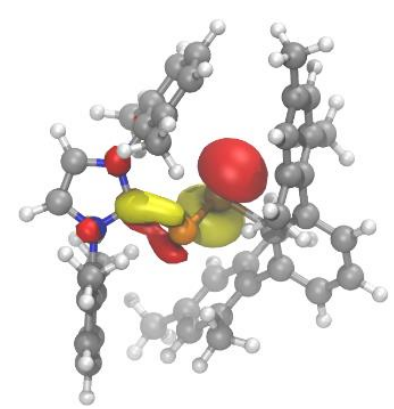

$\operatorname{LUMO}(-1.200 \mathrm{eV})$ $\pi^{*}\left[\mathrm{p}_{\mathrm{z}}(\mathrm{Ge})+\pi(\mathrm{C}=\mathrm{P})\right]$

Figure S41. Selected Kohn-Sham isosurfaces (isovalue: $0.05 \mathrm{au}$ ) showing HOMO-1, HOMO, and LUMO in $\mathbf{1 a}$.

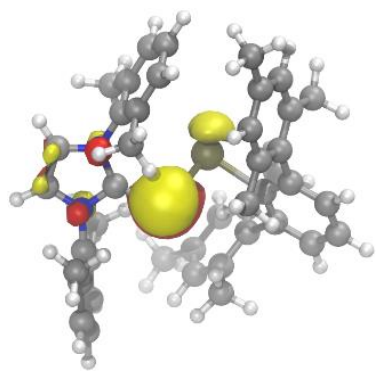

HOMO-1 (-4.669 eV)

$\mathrm{p}_{\mathrm{z}}(\mathrm{P})$ or $\pi(\mathrm{Sn}=\mathrm{P})$ largely located at $\mathrm{P}$

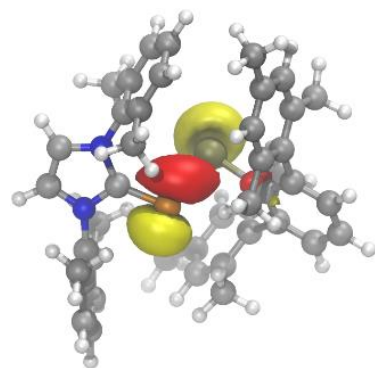

$\operatorname{HOMO}(-4.654 \mathrm{eV})$ $\sigma(\mathrm{Sn}-\mathrm{P})$

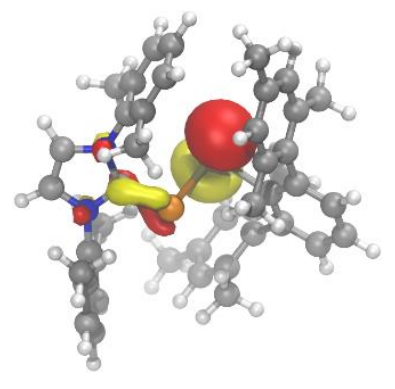

LUMO $(-1.315 \mathrm{eV})$ $\pi^{*}\left[\mathrm{p}_{\mathrm{z}}(\mathrm{Ge})+\pi(\mathrm{C}=\mathrm{P})\right]$

Figure S42. Selected Kohn-Sham isosurfaces (isovalue: $0.05 \mathrm{au}$ ) showing HOMO-1, HOMO, and LUMO in $\mathbf{2 a}$.

\section{NBO Analysis of 1a and 2a}

Table S7. NBO analysis of the Ge-P bond in 1a.

\begin{tabular}{lcc}
\hline NBO & Location $^{a}$ & Population \\
\hline$\sigma$ bond & $\mathrm{p}_{\mathrm{P}}(82.2 \%)-\mathrm{p}_{\mathrm{Ge}}(90.3 \%)$ & $1.902 \mathrm{e}$ \\
$\sigma^{*}$ bond & $\mathrm{p}_{\mathrm{P}}(82.2 \%)-\mathrm{p}_{\mathrm{Ge}}(90.3 \%)$ & $0.019 \mathrm{e}$ \\
Lone pair & $\mathrm{s}_{\mathrm{Ge}}(79.3 \%)$ & $1.955 \mathrm{e}$ \\
Lone pair* & $\mathrm{p}_{\mathrm{Ge}}(98.8 \%)$ & $0.398 \mathrm{e}$ \\
Lone pair & $\mathrm{S}(68.4 \%)$ & $1.915 \mathrm{e}$ \\
\hline a
\end{tabular}

${ }^{a}$ The percentage "s" or "p" character in parenthesis. 
Table S8. NBO analysis of the Sn-P bond in $2 \mathbf{a}$.

\begin{tabular}{lcc}
\hline & Location $^{a}$ & Population \\
\hline$\sigma$ bond & $\mathrm{p}_{\mathrm{P}}(83.5 \%)-\mathrm{p}_{\mathrm{Sn}}(91.9 \%)$ & $1.907 \mathrm{e}$ \\
$\sigma^{*}$ bond & $\mathrm{p}_{\mathrm{P}}(83.5 \%)-\mathrm{p}_{\mathrm{Sn}}(91.9 \%)$ & $0.030 \mathrm{e}$ \\
Lone pair & $\mathrm{SSn}_{\mathrm{Sn}}(87.1 \%)$ & $1.971 \mathrm{e}$ \\
Lone pair $*$ & $\mathrm{p}_{\mathrm{Sn}}(96.3 \%)+\mathrm{p}_{\mathrm{Sn}}(99.4 \%)$ & $0.405+0.314 \mathrm{e}$ \\
Lone pair & $\mathrm{S}_{\mathrm{P}}(68.9 \%)$ & $1.910 \mathrm{e}$ \\
Lone pair & $\mathrm{sp}_{\mathrm{C}}{ }_{\mathrm{C}}$ & $1.558 \mathrm{e}$ \\
\hline
\end{tabular}

${ }^{a}$ The percentage "s" or "p" character in parenthesis.

\section{Calculated UV-Vis Values}

Table S9. Excerpt from the TD-DFT calculation of 1a.

\begin{tabular}{cccc}
\hline Wavelength, nm & MO contribution & $\mathrm{f}$ & Contribution, \% \\
\hline 457.1 & HOMO $\rightarrow$ LUMO & 0.0138 & 96 \\
370.2 & HOMO $\rightarrow \rightarrow$ LUMO+1 & 0.0333 & 79 \\
& HOMO $\rightarrow$ LUMO+1 & & 10 \\
364.7 & HOMO $\rightarrow$ LUMO+2 & 0.0108 & \\
312.1 & HOMO $\rightarrow \rightarrow$ LUMO+5 & 0.0623 & 48 \\
& HOMO $\rightarrow$ LUMO+6 & & 13 \\
303.9 & HOMO-3 $\rightarrow$ LUMO & 0.0222 & 44 \\
& HOMO-2 $\rightarrow$ LUMO & & 26 \\
\hline
\end{tabular}

Table S10. Excerpt from the TD-DFT calculation of $\mathbf{2 a}$.

\begin{tabular}{cccc}
\hline Wavelength, nm & MO contribution & $\mathrm{f}$ & Contribution, \% \\
\hline 482.6 & HOMO $-1 \rightarrow$ LUMO & 0.0098 & 95 \\
363.8 & HOMO $\rightarrow$ LUMO+1 & 0.0032 & 71 \\
320.9 & HOMO $\rightarrow$ LUMO+5 & 0.1144 & 37 \\
& HOMO-1 $\rightarrow$ LUMO+5 & & 36 \\
310.8 & HOMO $1 \rightarrow$ LUMO+6 & 0.0286 & 35 \\
& HOMO $\rightarrow$ LUMO+6 & & 33 \\
\hline
\end{tabular}


Comparison of the E-P Bonds in Tetrylene-Phosphinidene NHC Complexes 1b and 2b with $E-P n$ Bonds $(E=G e, S n ; P n=P, N)$ in Related Compounds

Table S11: Ge-Pn bonds in 1b, XylGePXyl 2 , (PGe)Xyl, XylGeN(NHC), and Xyl $\mathbf{X}_{2} \mathrm{GePXyl}$

\begin{tabular}{|c|c|c|}
\hline $\begin{array}{c}\text { XylGeP(NHC) (1b) } \\
\mathrm{d}_{\mathrm{Ge}-\mathrm{P}}=2.267 \AA \\
\mathrm{WBI}=1.361 \\
\mathrm{MBO}=1.479 \\
\mathrm{P}-\mathrm{Ge}-\mathrm{C} 93.3^{\circ} \\
\mathrm{Ge}-\mathrm{P}-\mathrm{C} 97.7^{\circ}\end{array}$ & $\begin{array}{c}\text { XylGePXyl } 2 \\
\\
\mathrm{~d}_{\mathrm{Ge}-\mathrm{P}}=2.253 \AA \\
\mathrm{WBI}=1.256 \\
\mathrm{MBO}=1.408 \\
\rho=0.0955 \mathrm{au} \\
\mathrm{G} / \rho=0.542 \mathrm{au} \\
\mathrm{P}-\mathrm{Ge}-\mathrm{C} 94.2^{\circ} \\
\Sigma \mathrm{P} 353.3^{\circ}\end{array}$ & $\begin{array}{c}\mathbf{X y l G e} \equiv \mathbf{P} \\
\mathrm{d}_{\mathrm{Ge}-\mathrm{P}}=2.014 \AA \\
\mathrm{WBI}=2.797 \\
\mathrm{MBO}=2.925 \\
\rho=0.1302 \mathrm{au} \\
\mathrm{G} / \rho=0.509 \mathrm{au}\end{array}$ \\
\hline $\begin{array}{c}\text { XylGeN(NHC) } \\
\mathrm{d}_{\mathrm{Ge}-\mathrm{N}}=1.812 \AA \\
\mathrm{WBI}=0.898 \\
\mathrm{MBO}=1.297 \\
\rho=0.1355 \mathrm{au} \\
\mathrm{G} / \rho=1.340 \mathrm{au} \\
\mathrm{N}-\mathrm{Ge}-\mathrm{C} 97.2^{\circ} \\
\mathrm{Ge}-\mathrm{N}-\mathrm{C} 135.6^{\circ}\end{array}$ & $\begin{array}{c}\mathbf{X y l}_{\mathbf{2}} \mathbf{G e}=\mathbf{P X y l} \\
\mathrm{d}_{\mathrm{Ge}-\mathrm{P}}=2.152 \AA \\
\mathrm{WBI}=1.737 \\
\mathrm{MBO}=1.798 \\
\rho=0.1176 \mathrm{au} \\
\mathrm{G} / \rho=0.412 \mathrm{au} \\
\mathrm{Ge}-\mathrm{P}-\mathrm{C} 100.2^{\circ} \\
\Sigma \mathrm{Ge} 359.7^{\circ}\end{array}$ & $\begin{array}{c}\text { Ge=PXyl } \\
\mathrm{d}_{\mathrm{Ge}-\mathrm{P}}=2.164 \AA \\
\mathrm{WBI}=1.740 \\
\mathrm{MBO}=1.926 \\
\rho=0.1120 \mathrm{au} \\
\mathrm{G} / \rho=0.522 \mathrm{au} \\
\mathrm{Ge}-\mathrm{P}-\mathrm{C} 73.2^{\circ}\end{array}$ \\
\hline
\end{tabular}


Table S12: Sn-Pn bonds in 2b, XylSnPXyl 2 , (PSn)Xyl, XylSnN(NHC), and Xyl_SnPXyl.

\begin{tabular}{|c|c|c|}
\hline $\begin{array}{c}\text { XylSnP(NHC) (2b) } \\
\mathrm{d}_{\mathrm{Sn}-\mathrm{P}}=2.469 \AA \\
\mathrm{WBI}=1.256 \\
\mathrm{MBO}=1.362 \\
\mathrm{P}-\mathrm{Sn}-\mathrm{C} 91.0^{\circ} \\
\mathrm{Sn}-\mathrm{P}-\mathrm{C} 96.2^{\circ}\end{array}$ & $\begin{array}{c}\text { XylSnPXyl } 2 \\
\mathrm{~d}_{\mathrm{Sn}-\mathrm{P}}=2.485 \AA \\
\mathrm{WBI}=1.058 \\
\mathrm{MBO}=1.165 \\
\rho=0.0747 \mathrm{au} \\
\mathrm{G} / \rho=0.555 \mathrm{au} \\
\mathrm{P}-\mathrm{Sn}-\mathrm{C} 90.9^{\circ} \\
\Sigma \mathrm{P} 349.4^{\circ}\end{array}$ & $\begin{array}{c}\text { XylSn } \equiv \mathbf{P} \\
\mathrm{d}_{\mathrm{Sn}-\mathrm{P}}=2.198 \AA \\
\mathrm{WBI}=2.677 \\
\mathrm{MBO}=2.784 \\
\rho=0.1088 \mathrm{au} \\
\mathrm{G} / \rho=0.544 \mathrm{au}\end{array}$ \\
\hline $\begin{array}{c}\text { XylSnN(NHC) } \\
\\
\mathrm{d}_{\mathrm{N}-\mathrm{Sn}}=2.012 \AA \\
\mathrm{WBI}=0.795 \\
\mathrm{MBO}=1.045 \\
\rho=0.1110 \mathrm{au} \\
\mathrm{G} / \rho=1.218 \mathrm{au} \\
\mathrm{N}-\mathrm{Sn}-\mathrm{C} 94.8^{\circ} \\
\mathrm{Sn}-\mathrm{N}-\mathrm{C} 138.7^{\circ}\end{array}$ & $\begin{array}{c}\mathbf{X y l}_{2} \mathbf{S n}=\mathbf{P X y l} \\
\mathrm{d}=2.347 \AA \\
\mathrm{WBI}=1.619 \\
\mathrm{MBO}=1.762 \\
\rho=0.0949 \mathrm{au} \\
\mathrm{G} / \rho=0.468 \mathrm{au} \\
\mathrm{Sn}-\mathrm{P}-\mathrm{C} 99.3^{\circ} \\
\Sigma \mathrm{Sn} 358.9^{\circ}\end{array}$ & $\begin{array}{c}\text { Sn=PXyl } \\
\mathrm{d}=2.366 \AA \\
\mathrm{WBI}=1.652 \\
\mathrm{MBO}=1.837 \\
\rho=0.0902 \mathrm{au} \\
\mathrm{G} / \rho=0.555 \mathrm{au} \\
\mathrm{Sn}-\mathrm{P}-\mathrm{C} 75.2^{\circ}\end{array}$ \\
\hline
\end{tabular}




\section{Bond Dissociation Studies}

Table S13. Zero-point corrected dissociation energies (kcal/mol) in $\mathbf{1 b}$.

\begin{tabular}{lccc}
\hline Bond & Heteropolar cleavage & Homopolar cleavage & Reverse-heteropolar cleavage \\
\hline $\mathrm{P}-\mathrm{C}_{\mathrm{NHC}}$ & +34.16 & +195.40 & +274.74 \\
$\mathrm{Ge}-\mathrm{P}$ & +199.17 & +70.06 & +208.77 \\
\hline
\end{tabular}

Table S14. Zero-point corrected dissociation energies $(\mathrm{kcal} / \mathrm{mol})$ in $\mathbf{2 b}$.

\begin{tabular}{lccc}
\hline Bond & Heteropolar cleavage & Homopolar cleavage & Reverse-heteropolar cleavage \\
\hline $\mathrm{P}-\mathrm{C}_{\mathrm{NHC}}$ & -37.39 & +164.06 & +236.79 \\
$\mathrm{Sn}-\mathrm{P}$ & +11.95 & -3.11 & +187.53 \\
\hline
\end{tabular}

The heteropolar bond cleavage of this bond for complexes $\mathbf{1 b}$ and $\mathbf{2 b}$ (Me groups at $\mathrm{N}$ atoms and 2,6$\mathrm{Me}_{2} \mathrm{C}_{6} \mathrm{H}_{3}$ group at $\mathrm{E}$ centers) is strongly favored over the homopolar and reverse heteropolar cleavages (Tables S13 and S14). Different situation was observed for the E-P bonds of corresponding model compounds, where the homopolar bond cleavage is strongly preferred.

The most favored $\mathrm{P}-\mathrm{C}_{\mathrm{NHC}}$ dissociation process in $\mathbf{1 b}$ and $\mathbf{2} \mathbf{b}$ was found to proceed with simultaneous aromatic group 1,2-migration, leading to species $\mathbf{1 b}^{\mathbf{B}}$ and $\mathbf{2} \mathbf{b}^{\mathbf{B}}$ (Scheme S1) through a relatively lowlying barrier $\left(\Delta \mathrm{E}^{\ddagger} \mathrm{ZPE}=35.28\right.$ and $39.31 \mathrm{kcal} / \mathrm{mol}$ for $\mathrm{Ge}$ and $\mathrm{Sn}$, respectively $)$. The driving force for this E-to-P aryl group migration is the higher stability of bent compounds $\mathbf{1 b}^{\mathbf{B}}$ and $\mathbf{2 b}^{\mathbf{B}}$ with respect to the $\mathrm{XylGe} \equiv \mathrm{P} \mathbf{1 b}^{\mathbf{L}}(\Delta \Delta \mathrm{EZPE}=+10.98 \mathrm{kcal} / \mathrm{mol})$ and $\mathrm{XylSn} \equiv \mathrm{P} 2 \mathbf{b}^{\mathbf{L}}(\Delta \Delta \mathrm{EZPE}=+20.57 \mathrm{kcal} / \mathrm{mol})$ isomers , that display linear geometry at the central tetrel atom and typical set of triple bond molecular orbitals.

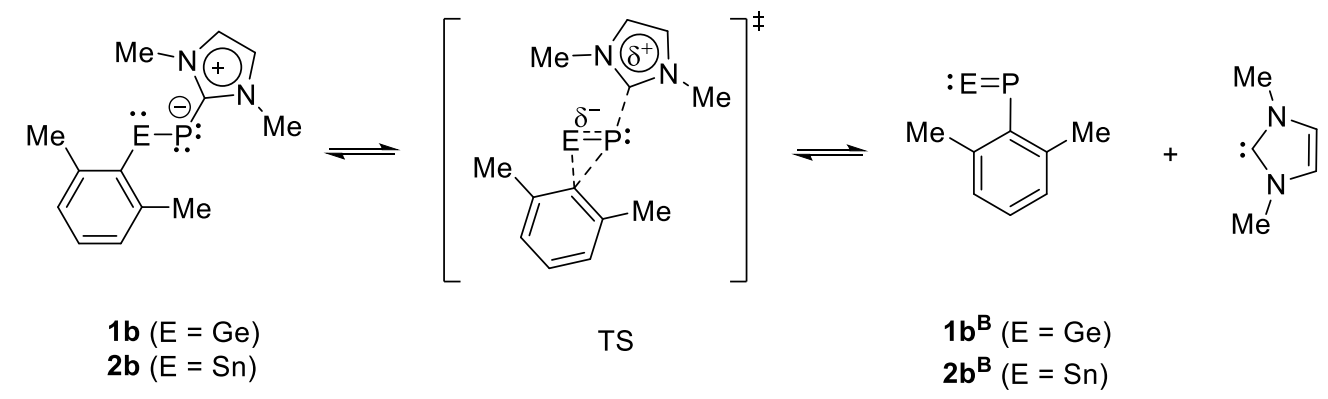

Scheme S1. P- $\mathrm{C}_{\mathrm{NHC}}$ bond cleavage in $\mathbf{1 b}$ and $\mathbf{2 b}$. 


\section{QTAIM Analysis}

As expected for dative bonds, ${ }^{\mathrm{S} 29}$ the bond critical points (BCPs) for the $\mathrm{C}_{\mathrm{NHC}}-\mathrm{P}$ bonds in $\mathbf{1 a}(\rho=0.1486$ $\left.\mathrm{e} / \mathrm{a} 0^{3}, \varepsilon=0.127\right)$ and $2 \mathrm{a}\left(\rho=0.1504 \mathrm{e} / \mathrm{a}^{3}, \varepsilon=0.139\right)$ are located closer to the phosphorus (the electron acceptor center). The $\nabla^{2} \rho$ function shows a pronounced minimum, which is a valence-shell charge concentration $\mathrm{VSCC}_{\mathrm{C}}$ corresponding to the electron donating carbene atom, and another shoulder VSCC $_{P}$ attributable to the partner phosphorus atom (Figures S43 and S44). Both are located within the basin of the donor atom which constitutes a signature for dative bonds. Different situation was observed for the E-P bonds of corresponding model compounds, where the homopolar bond cleavage is strongly preferred, the BCPs are more centrally located and both VSCCs are less intense suggesting electron sharing covalent bonds.
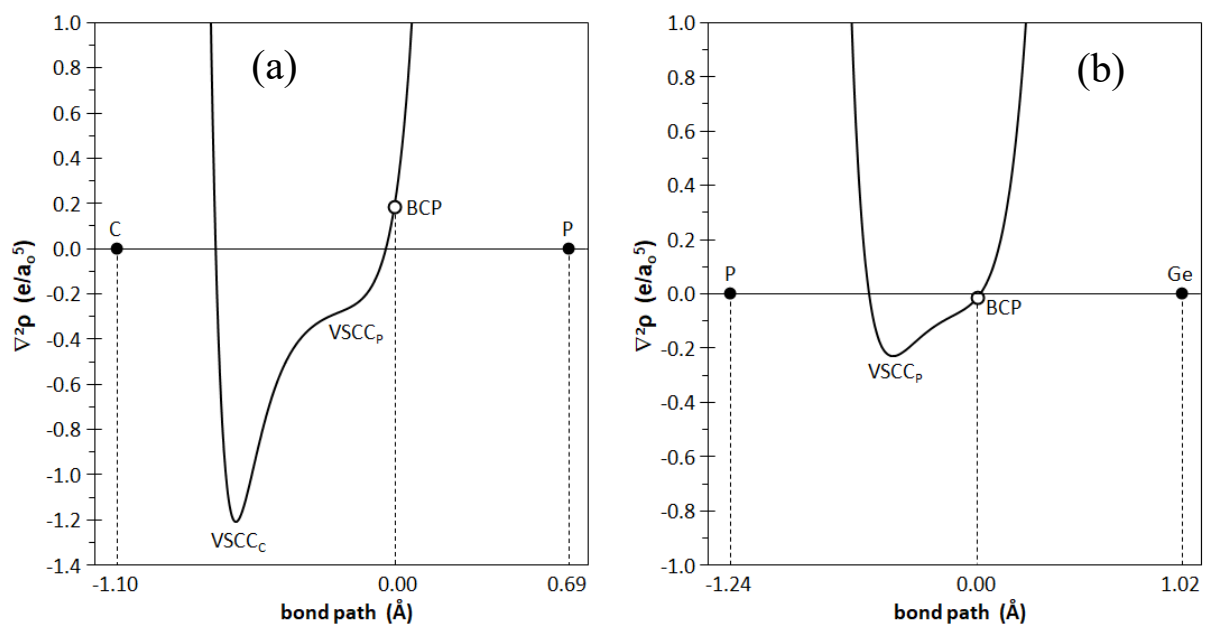

Figure S43. Computed (B3LYP-D3/def2-TZVPP//B3LYP-D3/def2-TZVP) variation of the Laplacian of electron density $\nabla^{2} \rho$ for 1 a along the $\mathrm{P}-\mathrm{C}$ (a) and Ge-P (b) bond paths.
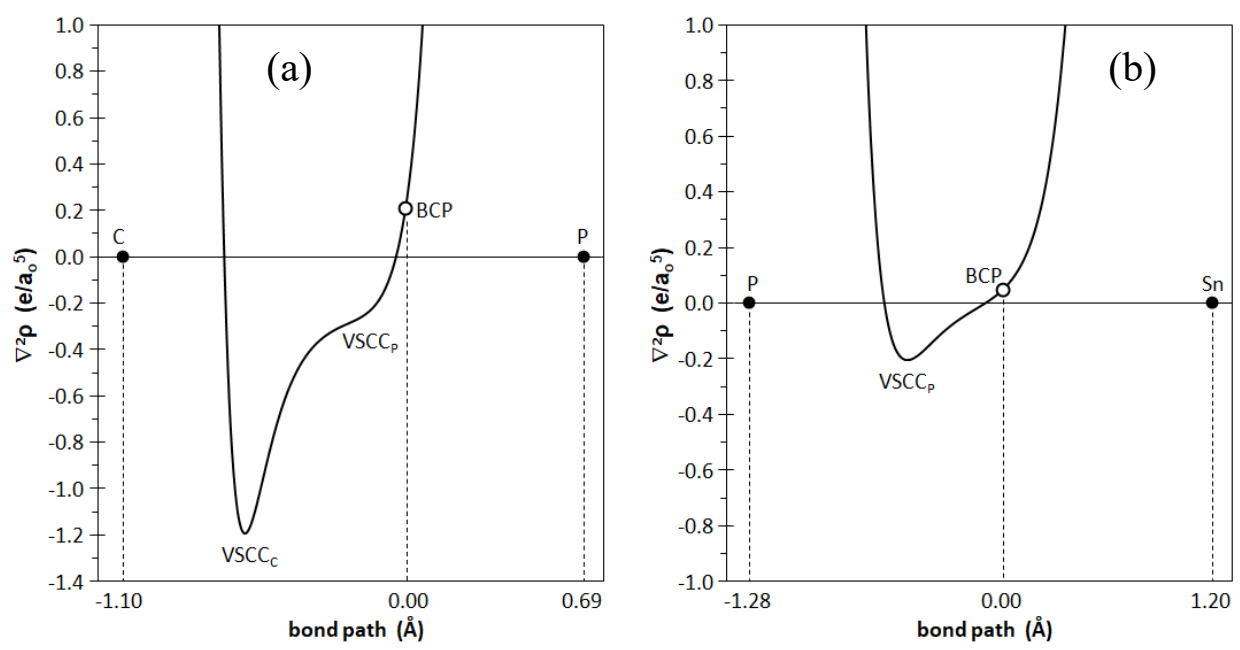

Figure S44. Computed (B3LYP-D3/def2-TZVPPecp//B3LYP-D3/def2-TZVPecp) variation of the Laplacian of electron density $\nabla^{2} \rho$ for $2 \mathbf{a}$ along the $\mathrm{P}-\mathrm{C}(\mathrm{a})$ and $\mathrm{Sn}-\mathrm{P}$ (b) bond paths 


\section{Energetics for the Reaction of Stannylene-Phosphinidene NHC Complex with Ketenes}

The reaction was modeled using parent ketene $\left(\mathrm{H}_{2} \mathrm{C}=\mathrm{C}=\mathrm{O}\right)$ and a model stannylene-phosphinidene NHC complex 2c bearing methyl groups at either the NHC nitrogen atoms and at the metal center. The concerted $[2+2]$ cycloaddition process is slightly exergonic $(\Delta \mathrm{EZPE}=-5.88 \mathrm{kcal} / \mathrm{mol})$ and occurs via a moderate transition state $(\mathrm{TS})\left(\Delta \mathrm{EZPE}^{\ddagger}=25.21 \mathrm{kcal} / \mathrm{mol}\right)$. The reaction with formaldehyde was also studied for comparison and turns out to be less exergonic $(\triangle \mathrm{EZPE}=-1.70 \mathrm{kcal} / \mathrm{mol})$ and with a lower barrier $\left(\Delta \mathrm{EZPE}^{\ddagger}=21.29 \mathrm{kcal} / \mathrm{mol}\right)$.

\section{Model Hetrocycle 4c}

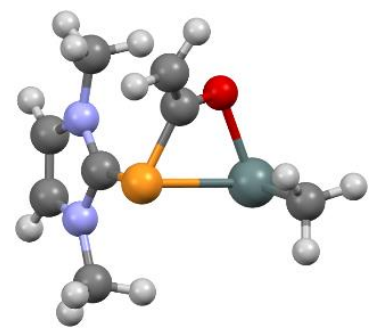

$$
\begin{aligned}
& \mathrm{d}_{\mathrm{Sn}-\mathrm{P}}=2.788 \AA, \mathrm{WBI}=0.531, \mathrm{MBO}=0.610 \\
& \mathrm{~d}_{\mathrm{Sn}-\mathrm{O}}=2.173 \AA, \mathrm{WBI}=0.365, \mathrm{MBO}=0.528 \\
& \mathrm{~d}_{\mathrm{P}-\mathrm{C}}=1.865 \AA, \mathrm{WBI}=0.954, \mathrm{MBO}=0.985 \\
& \mathrm{~d}_{\mathrm{O}-\mathrm{C}}=1.333 \AA, \mathrm{WBI}=1.127, \mathrm{MBO}=1.176
\end{aligned}
$$

Figure S45. Selected computed (B3LYP-D3/def2-TZVPPecp//B3LYP-D3/def2-TZVPecp) geometrical and bonding features of model heterocycle $\mathbf{4 c}$.

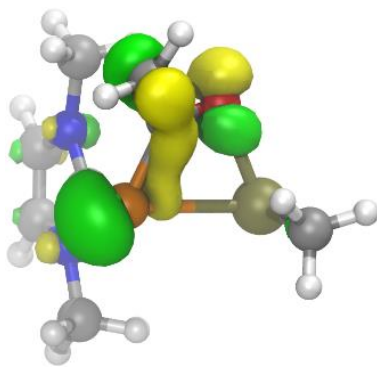

HOMO-2 (-5.695 eV) $\mathrm{p}_{\mathrm{z}}(\mathrm{P})+\pi(\mathrm{C}=\mathrm{C})$

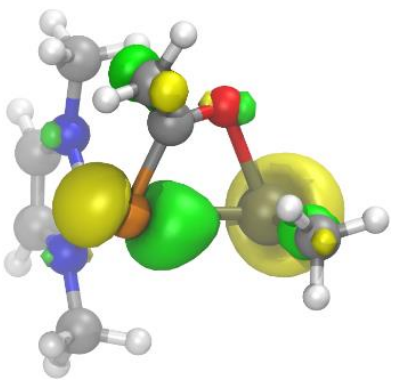

$\operatorname{HOMO}(-5.030 \mathrm{eV})$ $\sigma(\mathrm{Sn}-\mathrm{P})$

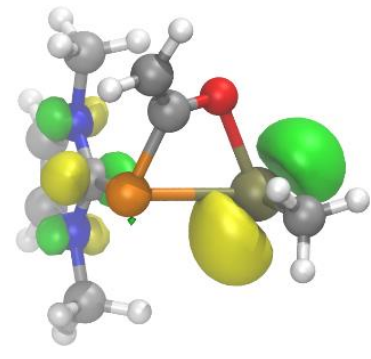

$\operatorname{LUMO}(-0.977 \mathrm{eV})$ $\mathrm{p}_{z}(\mathrm{Sn})$

Figure S46. Computed (B3LYP-D3/def2-TZVPPecp//B3LYP-D3/def2-TZVPecp) Kohn-Sham isosurfaces (isovalue: $0.05 \mathrm{au}$ ) showing HOMO-2, HOMO, and LUMO in the model heterocycle 4c. 


\section{Phosphastannene 5a}

Sn-P bond characteristics (B3LYP-D3/Def2-TZVP(ecp)//B3LYP-D3/Def2-TZVP(ecp):

$\mathrm{d}_{\mathrm{Sn}-\mathrm{P}}=2.388 \AA$

$\mathrm{WBI}=1.170$

$\mathrm{MBO}=1.388$

$\rho=0.0909 \mathrm{au}$

$\mathrm{G} / \rho=0.4416 \mathrm{au}$

$\mathrm{P}-\mathrm{Sn}-\mathrm{C} 91.0^{\circ}$

$\mathrm{Sn}-\mathrm{P}-\mathrm{C} 96.2^{\circ}$
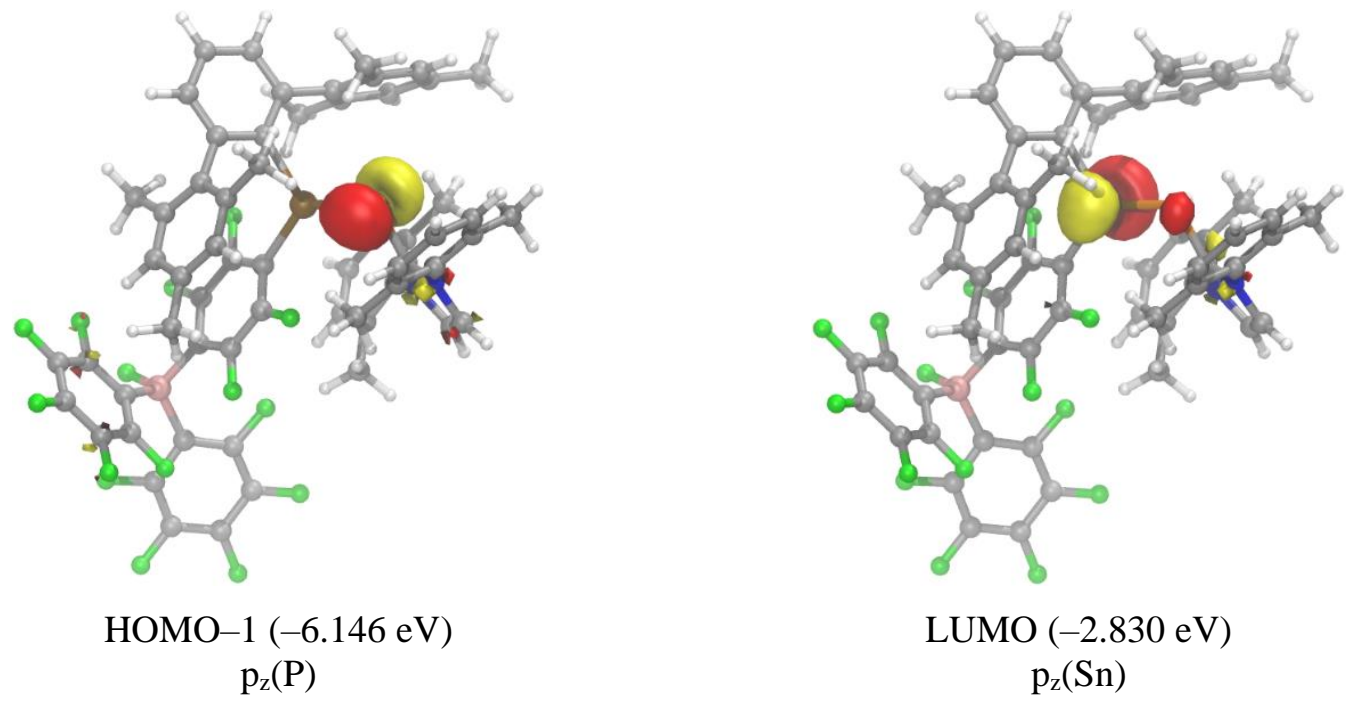

Figure S47. Computed (B3LYP-D3/def2-TZVPPecp//B3LYP-D3/def2-TZVPecp) Kohn-Sham isosurfaces (isovalue: $0.06 \mathrm{au}$ ) showing HOMO-1, and LUMO in 5a (HOMO, and HOMO-2 to HOMO-6 are at $\mathrm{Ar}^{\mathrm{F}}$-based MOs). 


\section{Calculated structures}

Cartesian coordinates (in $\AA$ ) and ZPE-correction (hartrees) for all computed species at the optimization level. Imaginary frequency (cm-1) for transition states. Electronic energies (hartrees) at the DLPNOCCSD(T)/def2-TZVPPecp level unless otherwise stated.

$1 \mathbf{a}$

$\begin{array}{lr}\text { Ge } & 0.241246 \\ \text { P } & 2.496069 \\ \text { C } & 2.789935 \\ \text { N } & 3.749344 \\ \text { C } & 3.828588 \\ \text { C } & 2.906774 \\ \text { N } & 2.273865 \\ \text { H } & 4.524838 \\ \text { H } & 2.642147 \\ \mathrm{C} & 4.483652 \\ \mathrm{C} & 3.924643 \\ \mathrm{C} & 4.656273 \\ \mathrm{C} & 5.884827 \\ \mathrm{C} & 6.407891 \\ \mathrm{C} & 5.713879 \\ \mathrm{C} & 2.564564 \\ \mathrm{H} & 2.467389 \\ \mathrm{H} & 2.358093 \\ \mathrm{H} & 1.797732 \\ \mathrm{H} & 4.248444 \\ \mathrm{H} & 6.436503 \\ \mathrm{H} & 7.360711 \\ \mathrm{C} & 6.236903 \\ \mathrm{H} & 6.303050 \\ \mathrm{H} & 7.227245 \\ \mathrm{H} & 5.570181 \\ \mathrm{C} & 1.241398 \\ \mathrm{C} & -0.033937 \\ \mathrm{C} & -1.017983 \\ \mathrm{C} & -0.731512 \\ \mathrm{C} & 0.546521 \\ \mathrm{C} & 1.561230 \\ \mathrm{C} & -0.346426 \\ \mathrm{H} & -0.014155 \\ \mathrm{H} & 0.141276 \\ \mathrm{H} & -1.419934 \\ \mathrm{H} & -2.020462 \\ \mathrm{H} & -1.511414 \\ \mathrm{H} & 0.765619 \\ \mathrm{C} & 2.933638 \\ \mathrm{H} & 3.713642 \\ \mathrm{H} & 3.092588 \\ \mathrm{H} & 3.054028 \\ \mathrm{C} & 0.166032 \\ \mathrm{C} & -0.027924 \\ \mathrm{C} & -0.146197\end{array}$

$$
\begin{array}{rr}
-0.075747 & 0.096686 \\
-0.047508 & -0.057375 \\
1.721382 & -0.036102 \\
2.304168 & 0.742681 \\
3.664179 & 0.495148 \\
3.943572 & -0.450756 \\
2.751403 & -0.774140 \\
4.294437 & 1.017055 \\
4.866554 & -0.932646 \\
1.609555 & 1.761645 \\
1.533262 & 3.038769 \\
0.868946 & 4.020569 \\
0.296061 & 3.725782 \\
0.377438 & 2.442037 \\
1.038764 & 1.432125 \\
2.099288 & 3.324777 \\
3.126426 & 2.968588 \\
2.083714 & 4.392924 \\
1.500770 & 2.825595 \\
0.795529 & 5.020035 \\
-0.222637 & 4.499656 \\
-0.083443 & 2.214046 \\
1.093362 & 0.025047 \\
2.118242 & -0.345933 \\
0.644301 & -0.035080 \\
0.546324 & -0.646707 \\
2.654862 & -1.766971 \\
3.128006 & -1.446098 \\
3.045736 & -2.427568 \\
2.516919 & -3.677655 \\
2.068239 & -3.971079 \\
2.127709 & -3.020424 \\
3.675338 & -0.082161 \\
2.989160 & 0.698302 \\
4.637983 & 0.091025 \\
3.817492 & 0.031713 \\
3.383387 & -2.197632 \\
2.447119 & -4.424920 \\
1.653993 & -4.944797 \\
1.606549 & -3.326753 \\
2.289789 & -2.985562 \\
0.651345 & -2.818175 \\
1.452015 & -4.397981 \\
-2.105065 & 0.177563 \\
-2.859966 & -0.986241 \\
-4.248166 & -0.909151
\end{array}
$$

$\mathrm{E}=-4193.197490827784$ au (B3LYP-D3/def2-TZVPecp)

-0.085997
0.086533
0.207844
-0.295398
-0.184055
0.120174
-0.142591
0.959744
0.807389
-0.408682
-1.484981
-1.374396
2.297340
2.228141
2.694052
3.014177
1.662423
-0.566820
0.401548
-1.129561
-1.110996
-2.440054
-2.569320
-3.481212
-2.460086
-2.690856
0.345753
1.585459
1.668453
0.565927
-0.657095
-0.788855
2.826893
2.666096
3.646056
3.137733
2.627708
0.683686
0.424913
1.698862
0.008993
-1.535457
-2.141282
-2.383238
-2.175501
-2.917917

0.318783

1.478523

1.416535

$-1.818483$

0.372713

2. 443168

$-2.318216$

$-3.185317$

$-4.445612$

$-4.872629$

$-3.992584$

$-2.723460$

$-2.764417$

$-2.439250$

$-1.921189$

$-3.583906$

$-5.112393$

$-6.256134$

$-6.720356$

$-6.241039$

$-6.906650$

$-4.302378$

$-1.806593$

$-2.356984$

$-1.011252$

$-1.320429$

2. 678634

3. 326442

4.509869

5.060317

4.406215

3.233586

2.751099

2.456127

3.469285

1.856476

5.008040

6.327346

6.156837

6.724557

7.101169

4.826029

2.585367

2. 389911

1.623745

3.222983 


\begin{tabular}{|c|c|c|c|}
\hline C & 2.814024 & 1.834102 & 0.037898 \\
\hline $\mathrm{N}$ & 3.790481 & 2.414168 & 0.806600 \\
\hline 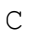 & 3.926692 & 3.759286 & 0.507225 \\
\hline C & 3.026859 & 4.040016 & -0.458030 \\
\hline $\mathrm{N}$ & 2.348833 & 2.862785 & -0.745499 \\
\hline $\mathrm{H}$ & 4.643680 & 4.381047 & 1.011010 \\
\hline $\mathrm{H}$ & 2.804945 & 4.955609 & -0.974340 \\
\hline & 4.511150 & 1.728404 & 1.8 \\
\hline C & 3.953913 & 1.682770 & 3.1 \\
\hline c & 4.676402 & 1.026179 & 4.1 \\
\hline C & 5.897995 & 0.432762 & 3.8 \\
\hline c & 6.421445 & 0.485230 & 2.5 \\
\hline C & 5.734092 & 1.135529 & 1.5 \\
\hline c & 2.602145 & 2.272029 & 3.3 \\
\hline $\mathrm{H}$ & 2.514667 & 3.289991 & 3.0 \\
\hline $\mathrm{H}$ & 2.401540 & 2.288857 & 4.4 \\
\hline $\mathrm{H}$ & 1.828436 & 1.667 & 2.9 \\
\hline $\mathrm{H}$ & 4.267980 & 0.975865 & 5.1 \\
\hline $\mathrm{H}$ & 6.444053 & -0.078076 & 4.6 \\
\hline $\mathrm{H}$ & 7.368920 & 0.009513 & 2.3 \\
\hline c & 6.255222 & 1.157 & 0.1 \\
\hline $\mathrm{H}$ & 6.347231 & 2.174951 & -0.2 \\
\hline $\mathrm{H}$ & 7.23 & 0.68 & 0.0 \\
\hline $\mathrm{H}$ & 5.571812 & 0.619486 & -0.5 \\
\hline C & 1.31 & 2.769 & -1.7 \\
\hline C & 0.060243 & 3.306020 & -1.43 \\
\hline C & -0.933889 & 3.204405 & -2.406840 \\
\hline $\mathrm{C}$ & -0.676703 & 2.590 & -3.6 \\
\hline C & 0.584380 & 2.084 & -3.8 \\
\hline C & 1.609116 & 2.166081 & -2.9 \\
\hline C & -0.224589 & 3.936721 & -0.1 \\
\hline $\mathrm{H}$ & 0.150444 & 3.318822 & 0.7 \\
\hline $\mathrm{H}$ & 0.245319 & 4.919465 & -0.0 \\
\hline $\mathrm{H}$ & -1.297105 & 4.063534 & 0.0 \\
\hline $\mathrm{H}$ & -1.923028 & 3.586943 & -2.1 \\
\hline $\mathrm{H}$ & -1.465475 & 2.501553 & -4.3 \\
\hline $\mathrm{H}$ & 0.781267 & 1.607314 & -4.8 \\
\hline C & 2.964477 & 1.591896 & -3.24 \\
\hline $\mathrm{H}$ & 3.761827 & 2.288710 & -2.9 \\
\hline $\mathrm{H}$ & 3.116782 & 0.683533 & -2.6 \\
\hline $\mathrm{H}$ & 3.060165 & 1.342525 & $-4 \cdot 3$ \\
\hline $\mathrm{C}$ & 0.021598 & -2.235657 & 0.1 \\
\hline $\mathrm{C}$ & -0.150223 & -2.995971 & -1.0 \\
\hline $\mathrm{C}$ & -0.239238 & -4.386788 & -0.9 \\
\hline & & -5 & \\
\hline
\end{tabular}

\begin{tabular}{|c|c|c|c|}
\hline $\mathrm{C}$ & 0.006186 & -4.287657 & 1.436972 \\
\hline $\mathrm{C}$ & 0.097307 & -2.897013 & 1.376696 \\
\hline $\mathrm{H}$ & -0.369886 & -4.960506 & -1.861373 \\
\hline 11 & -0.236301 & -6.111692 & 0.328848 \\
\hline $\mathrm{H}$ & 0.066246 & -4.784537 & 2.39859 \\
\hline $\mathrm{C}$ & -0.245912 & -2.316365 & -2.348947 \\
\hline $\mathrm{C}$ & 0.902054 & -2.134836 & -3.135101 \\
\hline $\mathrm{C}$ & 0.779897 & -1.519059 & -4.380232 \\
\hline $\mathrm{C}$ & -0.445800 & -1.080501 & -4.8657 \\
\hline $\mathrm{C}$ & -1.571461 & -1.255741 & -4.065 \\
\hline C & -1.493882 & -1.868836 & -2.81 \\
\hline C & 2.251831 & -2.580095 & $-2 \cdot 6$ \\
\hline $\mathrm{H}$ & 2.227829 & -3.605295 & -2.2 \\
\hline $\mathrm{H}$ & 2.586074 & -1.948831 & -1.8 \\
\hline $\mathrm{H}$ & 2.993556 & -2.514711 & -3.4 \\
\hline $\mathrm{H}$ & 1.669573 & -1.386353 & -4.9 \\
\hline $\mathrm{C}$ & -0.564240 & -0.446954 & -6.21 \\
\hline $\mathrm{H}$ & 0.415740 & -0.293551 & -6.67 \\
\hline $\mathrm{H}$ & -1.069483 & 0.520647 & -6.1 \\
\hline $\mathrm{H}$ & -1.147784 & -1.075221 & -6.9 \\
\hline $\mathrm{H}$ & -2.537312 & -0.915721 & -4.4 \\
\hline $\mathrm{C}$ & -2.740953 & -2.069548 & -2.00000 \\
\hline $\mathrm{H}$ & -3.603309 & -1.618291 & $-2 \cdot 4$ \\
\hline $\mathrm{H}$ & -2.641846 & -1.628393 & $-1 \cdot 0$ \\
\hline $\mathrm{H}$ & -2.946161 & -3.131859 & -1.8 \\
\hline $\mathrm{C}$ & 0.282865 & -2.104362 & 2.6 \\
\hline $\mathrm{C}$ & 1.560637 & -1.970929 & 3.1 \\
\hline $\mathrm{C}$ & 1.718995 & -1.193 & \\
\hline $\mathrm{C}$ & 0.648277 & -0.542112 & 4.9 \\
\hline $\mathrm{C}$ & -0.614353 & -0.694107 & 4.3 \\
\hline $\mathrm{C}$ & -0.817421 & -1.471410 & 3. \\
\hline C & 2.755092 & -2.638831 & 2 \\
\hline $\mathrm{H}$ & 2.660072 & -3.726619 & 2.5 \\
\hline $\mathrm{H}$ & 3.668791 & -2.360917 & 3.0 \\
\hline $\mathrm{H}$ & 2.864309 & -2.340302 & 1.5 \\
\hline $\mathrm{H}$ & 2.710533 & -1.089929 & 4.75992 \\
\hline $\mathrm{C}$ & 0.84 & 0.297492 & 6.17 \\
\hline $\mathrm{H}$ & 0.538903 & 1.334015 & 5.9 \\
\hline $\mathrm{H}$ & 1.884106 & 0.298765 & 6.4 \\
\hline $\mathrm{H}$ & 0.239757 & -0.076984 & 7.00371 \\
\hline $\mathrm{H}$ & -1.467013 & -0.207210 & 4.83211 \\
\hline $\mathrm{C}$ & -2.210110 & -1.648417 & 2.68500 \\
\hline $\mathrm{H}$ & -2.460630 & -2.705937 & 2.58301 \\
\hline $\mathrm{H}$ & -2.315251 & -1.205511 & 1.69209 \\
\hline $\mathrm{H}$ & -2.943911 & -1.179823 & 3.3 \\
\hline
\end{tabular}

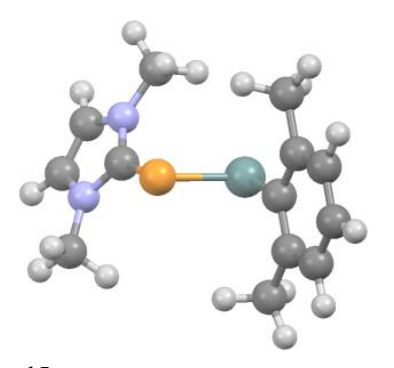

1b

\section{$\mathrm{E}=-3030.363422023708 \mathrm{au}$ $\mathrm{ZPE}=0.27480544 \mathrm{au}$}

$\begin{array}{rr}\mathrm{H} & 3.826497 \\ \mathrm{H} & 3.749221 \\ \mathrm{H} & 2.965021 \\ \mathrm{C} & 2.171871 \\ \mathrm{H} & 2.423662 \\ \mathrm{H} & 1.093408 \\ \mathrm{H} & 2.679696 \\ \mathrm{C} & 0.064570 \\ \mathrm{C} & -0.250945 \\ \mathrm{C} & -0.461483\end{array}$

2.657551
4.457894
4.654931
2.215857
1.177640
2.335920
2.872648
-2.111351
-2.712351
-4.089264
3.109145

1. 455026

$-1.178271$

$-2.269361$

$-2.472669$

$-2.360241$

$-2.974398$

$-0.116441$

1.112852

1.176305 


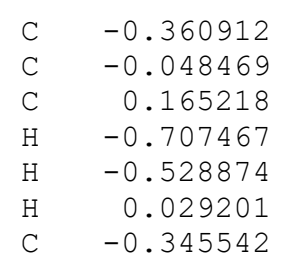

\begin{abstract}
$-4.875243$
$-4.283956$

$-2.908829$

$-4.547602$

$-5.943644$

$-4.893941$

$-1.883746$
\end{abstract}

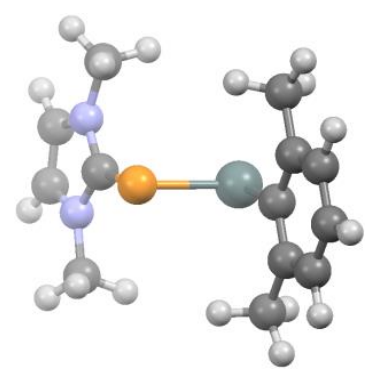

2b

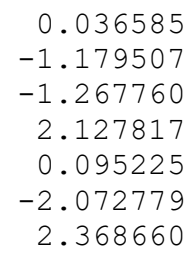

0.036585
-1.179507
-1.267760
2.127817
0.095225
-2.072779
2.368660

$\begin{array}{rr}\mathrm{H} & 0.632598 \\ \mathrm{H} & -1.011337 \\ \mathrm{H} & -0.725998 \\ \mathrm{C} & 0.519582 \\ \mathrm{H} & -0.105177 \\ \mathrm{H} & 1.557861 \\ \mathrm{H} & 0.386656\end{array}$

$-1.483676$

$-1.025116$

$-2.471392$

$-2.293953$

$-1.420197$

$-1.952376$

$-3.006101$

\section{$\mathrm{E}=-1167.297933547941 \mathrm{au}$ $\mathrm{ZPE}=0.27389797 \mathrm{au}$}

$$
\begin{array}{rr}
0.053921 & -0.016127 \\
-0.056663 & 0.013796 \\
1.720963 & 0.033884 \\
2.515758 & 1.125780 \\
3.824830 & 0.742752 \\
3.854774 & -0.608453 \\
2.563566 & -1.033005 \\
2.044420 & 2.497439 \\
1.964724 & 2.824405 \\
1.057217 & 2.554841 \\
2.745120 & 3.134181 \\
4.610397 & 1.455618 \\
4.671229 & -1.296254 \\
2.153819 & -2.418280 \\
1.140565 & -2.524548 \\
2.158663 & -2.711221 \\
2.839437 & -3.049014
\end{array}
$$

$$
\begin{array}{r}
-0.033883 \\
-0.109678 \\
-0.259069 \\
-0.333038 \\
-0.254569 \\
-0.105166 \\
-0.318058 \\
-0.453077 \\
-0.309972 \\
-0.010877 \\
0.977426 \\
-0.744844 \\
-0.186357 \\
-0.001112 \\
-0.733567 \\
0.988536 \\
-0.175215
\end{array}
$$

-2.177942
-2.884506
-4.271684
-4.963718
-4.268986
-2.881803
-4.811864
-6.040182
-4.806948
-2.161795
-1.711676
-1.351451
-2.835869
-2.155632
-1.343896
-1.707221
-2.826872

$-0.016650$

1. 193359

1.180234

$-0.020481$

$-1.219342$

$-1.228468$

2. 118762

$-0.021896$

$-2.159361$

2.513532

2.638709

2.581793

3. 352958

$-2.546332$

$-2.614612$

$-2.667753$

$-3.388295$

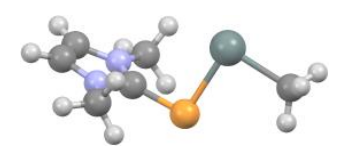

2c

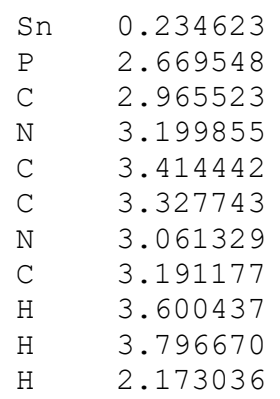

0.052220
-0.043788
1.716882
2.413321
3.750083
3.897608
2.649157
1.825452
0.819166
2.443672
1.759712
$\mathrm{E}=-897.433386868963 \mathrm{au}$

$$
\mathrm{ZPE}=0.16507615 \mathrm{au}
$$

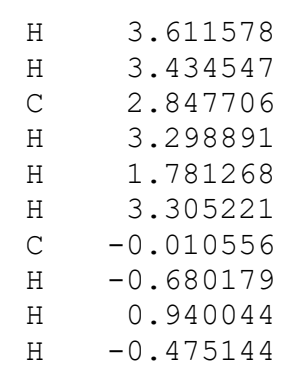

4.469916

4.770413

2. 361819

1.401106

2.302157

3.152687

$-2.147192$

$-2.326547$

$-2.646661$

$-2.573766$
1.719605

$-1.012659$

$-2.329006$

$-2.568208$

$-2.548568$

$-2.920449$

0.011425

$-0.833085$

$-0.172576$

0.903528

\section{$\mathrm{HCHO}$}

$E=-114.336522181666 \mathrm{au}$

$\mathrm{ZPE}=0.02649305 \mathrm{au}$ 
$\begin{array}{lll}0 & -2.969146 & -0.068187\end{array}$

C $\quad-2.795503 \quad 0.276553$
1.583579

2.718864
$\mathrm{H} \quad-2.695098$

H $\quad-2.725379$
1.343361

$-0.451750$
3.000098

3.550836

\section{$\mathrm{TS}\left(\mathbf{2} \mathbf{c}+\mathrm{HCHO} \rightarrow \mathbf{4} \mathbf{c}^{\mathbf{H} \mathbf{2}}\right)$}

$$
\mathrm{E}=-1011.73808951889 \mathrm{au}
$$

$$
\mathrm{ZPE}=0.19368437 \mathrm{au}
$$$$
\bar{v}=-128.48 \mathrm{~cm}^{-1}
$$

$$
\begin{array}{r}
0.286285 \\
-0.039606 \\
0.016965 \\
0.839434 \\
0.554466 \\
-0.444596 \\
-0.771052 \\
1.932832 \\
2.402425 \\
2.657647 \\
1.583067 \\
1.083230 \\
-0.952391
\end{array}
$$

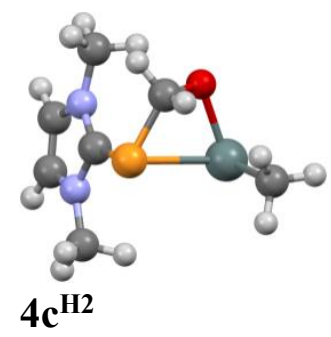

$\begin{array}{ll}\mathrm{Sn} & 0.139652 \\ \mathrm{P} & 2.655526 \\ \mathrm{C} & 2.875995 \\ \mathrm{~N} & 2.534990 \\ \mathrm{C} & 2.783562 \\ \mathrm{C} & 3.290712 \\ \mathrm{~N} & 3.345810 \\ \mathrm{C} & 1.924411 \\ \mathrm{H} & 2.571485 \\ \mathrm{H} & 1.765315 \\ \mathrm{H} & 0.968306 \\ \mathrm{H} & 2.577426 \\ \mathrm{H} & 3.617394\end{array}$

\section{$\mathrm{H}_{2} \mathrm{C}=\mathrm{C}=\mathrm{O}$}

\begin{abstract}
0.199537
0.004607

1. 777682

2. 649350

3.950119

3.895068

2. 560802

2. 247352

1.547030

3.133519

1.757958

4.787364

4.676745
\end{abstract}

$$
\begin{aligned}
& \mathrm{E}=-1011.77819329886 \mathrm{au} \\
& \mathrm{ZPE}=0.19714333 \mathrm{au}
\end{aligned}
$$

$$
\begin{array}{r}
-0.951958 \\
0.281265 \\
0.042960 \\
1.038885 \\
0.649761 \\
-0.599322 \\
-0.967732 \\
2.290728 \\
2.818755 \\
2.900231 \\
2.097045 \\
1.290759 \\
-1.259891
\end{array}
$$

1.942476

1.282164

1.344918

2.729730

$-2.509289$

$-2.822856$

$-2.751162$

$-3.071047$

0.065239

$-0.326943$

$-1.314205$

0.241991
$-1.778932$

$-1.317608$

$-2.453868$

$-2.332677$

$-0.079036$

$-0.939154$

$-0.254315$

0.791012

$-2.222428$

$-2.536419$

$-2.258856$

$-3.252833$ $\begin{array}{rr}2.112738 & -2.266103 \\ 1.590035 & -2.151489 \\ 1.455582 & -2.723867 \\ 2.993520 & -2.884824 \\ -1.956702 & -0.566016 \\ -2.254656 & -1.161617 \\ -2.595366 & -0.833079 \\ -2.110521 & 0.488651 \\ -0.153083 & -2.281481 \\ -0.673096 & -1.484310 \\ -1.758353 & -1.322744 \\ -0.522490 & -1.931014\end{array}$
$\mathrm{E}=152.360553198610 \mathrm{au}$ $\mathrm{ZPE}=0.03152559 \mathrm{au}$

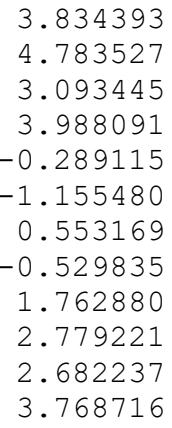

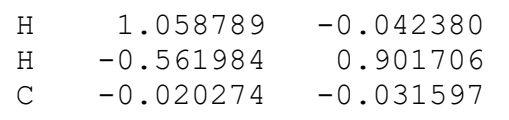

\begin{abstract}
0.000000
0.000000

$-0.000001$
\end{abstract}

$\begin{array}{ll}\text { C } & -0.677979 \\ \text { O } & -1.259715\end{array}$

$-1.163048$

$-2.166170$
$-0.000000$

0.000000 
$\mathrm{ZPE}=0.19836263 \mathrm{au}$

$\bar{v}=-184.48 \mathrm{~cm}^{-1}$

$\begin{array}{ll}\text { Sn } & 0.407126 \\ \mathrm{P} & 2.742226 \\ \mathrm{C} & 2.742562 \\ \mathrm{~N} & 2.562244 \\ \mathrm{C} & 2.737007 \\ \mathrm{C} & 3.041212 \\ \mathrm{~N} & 3.046306 \\ \mathrm{C} & 2.311354 \\ \mathrm{H} & 2.806601 \\ \mathrm{H} & 2.718816 \\ \mathrm{H} & 1.244025 \\ \mathrm{H} & 2.631798 \\ \mathrm{H} & 3.249124\end{array}$

$-0.479550$

0.075962

1.859733

2. 623851

3. 963386

4.049768

2.763658

2.104295

1.139104

2. 801855

1.972315

4. 728468

4. 904702

3.351193
4.150095
2.478421
3.667428
0.659506
-0.300695
1.105688
1.328087
0.090142
1.123133
1.894896
2.946857
1.404734

2.411677

1. 672103

1. 983413

3.312963

$-2.611996$

$-3.127975$

$-2.702795$

$-3.082258$

0.238638

$-0.234519$

$-0.900692$

$-1.032953$

$-1.350662$
$-2.278909$

$-2.303018$

$-2.768071$

$-2.799768$

0.248160

0.268396

$-0.742405$

0.974294

$-1.854812$

$-2.226002$

$-3.068288$

$-2.903551$

$-3.925921$

\section{$\mathrm{E}=-1049.8083398251 \mathrm{au}$ \\ $\mathrm{ZPE}=0.20163713 \mathrm{au}$}

$\begin{array}{lrr}\text { Sn } & 0.024700 & -0.037682 \\ \text { P } & 2.806976 & -0.007048 \\ \text { C } & 2.761399 & 1.798433 \\ \text { N } & 2.826629 & 2.481650 \\ \text { C } & 2.801341 & 3.842741 \\ \text { C } & 2.726879 & 4.011921 \\ \text { N } & 2.708595 & 2.753975 \\ \mathrm{C} & 2.848378 & 1.845264 \\ \text { H } & 3.697676 & 1.166132 \\ \text { H } & 2.928440 & 2.615359 \\ \text { H } & 1.930422 & 1.274041 \\ \text { H } & 2.839675 & 4.558482 \\ \text { H } & 2.688739 & 4.906477\end{array}$

H 2.688739

\begin{abstract}
0.125747
$-0.048902$

$-0.011148$

1.168019

0.937703

$-0.399741$

$-0.977443$

2.470435

2.543748

3.233567

2.619573

1.738045

$-0.993344$
\end{abstract}

$\begin{array}{lr}\text { C } & 2.646483 \\ \text { H } & 3.471916 \\ \text { H } & 1.711008 \\ \text { H } & 2.718442 \\ \text { C } & 0.013122 \\ \text { H } & -0.964803 \\ \text { H } & 0.779460 \\ \text { H } & 0.193209 \\ \text { O } & 0.846454 \\ \text { C } & 2.111559 \\ \text { C } & 2.816694 \\ \text { H } & 3.849807 \\ \text { H } & 2.356689\end{array}$

2.532280
1.898644
2.040652
3.501217
-2.258368
-2.618523
-2.652828
-2.626750
0.058402
-0.337922
-1.029509
-1.285361
-1.349186
$-2.418065$

$-2.731241$

$-2.679024$

$-2.905999$

0.152473

$-0.175109$

$-0.515398$

1.165395

$-1.883285$

$-1.747343$

$-2.654717$

$-2.470857$

$-3.582330$

\section{$5 a$}

$E=-4539.013560915367 \mathrm{au}$ 


\begin{tabular}{|c|c|c|c|}
\hline $\mathrm{Sn}$ & 0.180293 & 0.012627 & -0.155912 \\
\hline $\mathrm{P}$ & 2.477863 & 0.011206 & -0.805122 \\
\hline $\mathrm{C}$ & 3.092992 & 1.655395 & -0.401143 \\
\hline $\mathrm{N}$ & 4.111705 & 2.175996 & -1.141693 \\
\hline $\mathrm{C}$ & 4.603720 & 3.326696 & -0.55408 \\
\hline $\mathrm{C}$ & 3.874919 & 3.537885 & 0.56181 \\
\hline $\mathrm{N}$ & 2.945788 & 2.512201 & 0.65363 \\
\hline $\mathrm{H}$ & 5.411822 & 3.882854 & -0.99199 \\
\hline $\mathrm{H}$ & 3.917064 & 4.320479 & 1.25 \\
\hline $\mathrm{C}$ & 4.601634 & 1.598433 & -2.363 \\
\hline $\mathrm{C}$ & 5.722530 & 0.767661 & -2.29 \\
\hline $\mathrm{C}$ & 6.184533 & 0.219351 & -3.4 \\
\hline $\mathrm{C}$ & 5.541635 & 0.491637 & -4.69 \\
\hline $\mathrm{C}$ & 4.423186 & 1.312867 & -4.72 \\
\hline $\mathrm{C}$ & 3.925100 & 1.884587 & -3.55 \\
\hline $\mathrm{H}$ & 7.049827 & -0.430863 & -3.475 \\
\hline $\mathrm{H}$ & 5.913600 & 0.057401 & -5.61 \\
\hline $\mathrm{H}$ & 3.923563 & 1.514794 & -5.6 \\
\hline $\mathrm{C}$ & 6.379068 & 0.448495 & -0.983 \\
\hline $\mathrm{H}$ & 5.673897 & -0.036833 & -0.304 \\
\hline $\mathrm{H}$ & 7.223137 & -0.223014 & -1.131 \\
\hline $\mathrm{H}$ & 6.745890 & 1.346429 & $-0.4 \varepsilon$ \\
\hline $\mathrm{C}$ & 2.687494 & 2.734485 & -3.56 \\
\hline $\mathrm{H}$ & 2.824363 & 3.667829 & -3.0 \\
\hline $\mathrm{H}$ & 2.400572 & 2.98 & -4.5 \\
\hline $\mathrm{H}$ & 1.854082 & 2.208750 & -3.0 \\
\hline $\mathrm{C}$ & 1.953407 & 2.430461 & 1.6 \\
\hline $\mathrm{C}$ & 0.989589 & 3.4425 & 1.768 \\
\hline $\mathrm{C}$ & -0.012849 & 3.299 & 2.72 \\
\hline $\mathrm{C}$ & -0.043017 & 2.196 & 3.5 \\
\hline $\mathrm{C}$ & 0.9 & $1.245^{\circ}$ & 3.5 \\
\hline $\mathrm{C}$ & 2.010688 & 1.3621 & 2.594 \\
\hline $\mathrm{H}$ & -0.787164 & 4.0507 & 2.789 \\
\hline $\mathrm{H}$ & -0.849844 & 2.086650 & 4.278 \\
\hline $\mathrm{H}$ & 0.973829 & 0.4136 & 4.20 \\
\hline $\mathrm{C}$ & 1.021542 & 4.660 & 0.8 \\
\hline $\mathrm{H}$ & 1.352299 & 4.43 & -0.12 \\
\hline $\mathrm{H}$ & 1.699650 & 5.41 & 1.297 \\
\hline $\mathrm{H}$ & 0.038477 & 5.11 & 0.832 \\
\hline $\mathrm{C}$ & 3.168786 & 0.409 & 2.62 \\
\hline $\mathrm{H}$ & 3.254467 & -0.035 & 3.617 \\
\hline $\mathrm{H}$ & 4.10 & 0. & 2.3 \\
\hline $\mathrm{H}$ & 3.049068 & -0.39 & 1.90 \\
\hline $\mathrm{C}$ & -0.796464 & -1.90 & -0.185 \\
\hline $\mathrm{C}$ & -0.499280 & -2.945 & 0.69170 \\
\hline $\mathrm{C}$ & -1.232748 & -4.1299 & 0.583 \\
\hline $\mathrm{C}$ & -2.221937 & -4.268698 & -0.38105 \\
\hline $\mathrm{C}$ & -2.486675 & -3.23 & -1.26 \\
\hline $\mathrm{C}$ & -1.772536 & -2.04 & -1.184 \\
\hline $\mathrm{H}$ & -1.017 & -4.9 & 1.26279 \\
\hline $\mathrm{H}$ & -2.780029 & -5.193821 & -0.44898 \\
\hline $\mathrm{H}$ & -3.239741 & -3.351763 & -2.03799 \\
\hline $\mathrm{C}$ & 0.591954 & -2.851 & 1.703 \\
\hline $\mathrm{C}$ & 1.896 & -3 & 1.340 \\
\hline $\mathrm{C}$ & 2.898092 & -3.2 & 2.304 \\
\hline $\mathrm{C}$ & 2.642259 & -2.84 & 3.622 \\
\hline $\mathrm{C}$ & 1.348381 & -2.468596 & 3.95792 \\
\hline $\mathrm{C}$ & 0.314059 & -2.462060 & 3.02110 \\
\hline $\mathrm{H}$ & 3.903517 & -3.506874 & 2.019 \\
\hline $\mathrm{H}$ & 1.128893 & -2.179733 & 4.97979 \\
\hline $\mathrm{C}$ & 2.212469 & -3.669975 & -0.06424 \\
\hline $\mathrm{H}$ & 1.923351 & -2.917637 & -0.798 \\
\hline $\mathrm{H}$ & 1.673399 & -4.584195 & -0.32323 \\
\hline $\mathrm{H}$ & 3.279496 & -3.854673 & -0.18030 \\
\hline $\mathrm{C}$ & 3.745746 & -2.848147 & 4.64488 \\
\hline $\mathrm{H}$ & 3.400856 & -2.461643 & 5.60396 \\
\hline $\mathrm{H}$ & 4.588902 & -2.235467 & 4.316 \\
\hline $\mathrm{H}$ & 4.128400 & -3.858547 & 4.808 \\
\hline $\mathrm{C}$ & -1.072095 & -2.049454 & 3.437 \\
\hline
\end{tabular}




\begin{tabular}{|c|c|c|c|}
\hline $\mathrm{H}$ & -1.133128 & -1.941628 & 4.520340 \\
\hline $\mathrm{H}$ & -1.819402 & -2.779384 & 3.124266 \\
\hline $\mathrm{H}$ & -1.360040 & -1.097227 & 2.989231 \\
\hline C & -1.984037 & -0.902803 & -2.119062 \\
\hline C & -0.968295 & -0.552348 & -3.03304 \\
\hline C & -1.094534 & 0.637554 & -3.758 \\
\hline C & -2.205036 & 1.457433 & -3.6338 \\
\hline C & -3.228609 & 1.051026 & -2.7744 \\
\hline 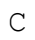 & -3.143611 & -0.107119 & -2.0168 \\
\hline $\mathrm{H}$ & -0.303213 & 0.913661 & -4.445 \\
\hline $\mathrm{H}$ & -4.104158 & 1.675318 & -2.66 \\
\hline $\mathrm{C}$ & 0.176218 & -1.477807 & -3.37 \\
\hline $\mathrm{H}$ & 1.100913 & -0.921789 & -3.527 \\
\hline $\mathrm{H}$ & -0.053190 & -2.010085 & -4.298 \\
\hline $\mathrm{H}$ & 0.353386 & -2.229905 & -2.6060 \\
\hline $\mathrm{C}$ & -2.319699 & 2.746822 & -4.39 \\
\hline $\mathrm{H}$ & -2.466748 & 3.588647 & -3.71 \\
\hline $\mathrm{H}$ & -3.177544 & 2.7266 & -5.0 \\
\hline $\mathrm{H}$ & -1.425181 & 2.939267 & -4.987 \\
\hline $\mathrm{C}$ & -4.268439 & -0.469207 & -1.084 \\
\hline $\mathrm{H}$ & -3.900331 & -0.783538 & -0.108 \\
\hline $\mathrm{H}$ & -4.856238 & -1.298311 & -1.4 \\
\hline $\mathrm{H}$ & -4.939152 & 0.376 & -0.9 \\
\hline $\mathrm{C}$ & -1.180893 & 1.62 & 0.0 \\
\hline $\mathrm{C}$ & -1.046769 & 2.76 & -0.7 \\
\hline $\mathrm{C}$ & -2.011639 & 3.752252 & -0.71 \\
\hline C & -3.185713 & 3.674891 & 0.028 \\
\hline $\mathrm{C}$ & -3.301391 & 2.522744 & 0.8 \\
\hline $\mathrm{C}$ & -2.3264 & 1.5342 & 0.8 \\
\hline F & 0.05 & 2.914 & -1.5 \\
\hline $\mathrm{F}$ & -1.7701 & 4.84 & $-1 \cdot 4$ \\
\hline F & -4.366439 & 2.310043 & 1.589 \\
\hline F & -2.509421 & 0.442916 & 1.597 \\
\hline B & -4.381100 & 4.821528 & -0.126 \\
\hline $\mathrm{F}$ & -5.5235 & 4.4524 & 0.616 \\
\hline $\mathrm{C}$ & -4.7636 & 4.80 & -1.7 \\
\hline $\mathrm{C}$ & -5.5611 & 3.781 & -2.23 \\
\hline $\mathrm{C}$ & -5.9324 & 3.667 & -3.570 \\
\hline $\mathrm{C}$ & -5.483992 & 4.606062 & -4.48489 \\
\hline C & -4.675447 & 5.639738 & -4.04474 \\
\hline $\mathrm{C}$ & -4.336792 & 5.720423 & -2.70023 \\
\hline $\mathrm{F}$ & -5.987 & 2.79 & -1.42 \\
\hline F & -6.6899 & 2.6418 & -3.98 \\
\hline F & -5.8044 & 4.497 & -5.780 \\
\hline F & -4.217406 & 6.542727 & -4.92434 \\
\hline F & -3.546543 & 6.756898 & -2.36435 \\
\hline $\mathrm{C}$ & -3.959439 & 6.316222 & 0.4262 \\
\hline $\mathrm{C}$ & -2.8746 & 6.621 & 1.2283 \\
\hline $\mathrm{C}$ & -2.6151 & 7.8842 & 1.7433 \\
\hline $\mathrm{C}$ & -3.492980 & 8.917911 & 1.47274 \\
\hline $\mathrm{C}$ & -4.612160 & 8.663045 & 0.69381 \\
\hline C & -4.822265 & 7.385965 & 0.19849 \\
\hline $\mathrm{F}$ & -1.977660 & 5.662588 & 1.57866 \\
\hline F & -1.529924 & 8.106806 & 2.50414 \\
\hline F & -3.271456 & 10.143598 & 1.96065 \\
\hline $\mathrm{F}$ & -5.471005 & 9.656052 & 0.43047 \\
\hline $\mathrm{F}$ & -5.925932 & 7.212897 & -0.5483 \\
\hline
\end{tabular}




\section{References}

S1. APEX suite of crystallographic software, APEX 3, version 2015.5-2, Bruker AXS Inc., Madison, Wisconsin, USA (2015).

S2. SAINT, Version 7.56a and SADABS Version 2008/1, Bruker AXS Inc., Madison, Wisconsin, USA (2008).

S3. G. M. Sheldrick, "SHELXL-2014”, University of Göttingen, Göttingen, Germany, (2014).

S4. Huebschle, C. B.; Sheldrick, G. M.; Dittrich, B. "SHELXLE”, J. Appl. Cryst. 2011, 44, 1281.

S5. G. M. Sheldrick, "SHELXL-97”, University of Göttingen, Göttingen, Germany, (1998).

S6. A. J. C. Wilson, International Tables for Crystallography, Vol. C, Tables 6.1.1.4 (pp. 500-502), 4.2.6.8 (pp. 219-222), and 4.2.4.2 (pp. 193-199); Kluwer Academic Publishers: Dordrecht, The Netherlands (1992).

S7. A. L. Spek, PLATON, A Multipurpose Crystallographic Tool, Utrecht University, Utrecht, The Netherlands (2010).

S8. ORCA - An $a b$ initio, DFT and semiempirical SCF-MO package. Written by F. Neese, Max Planck Institute for Bioinorganic Chemistry, D-45470 Mülheim/Ruhr, 2012. Version 3.0.3. Web page: http://www.cec.mpg.de/forum/portal.php. Neese, F. "The ORCA program system", WIREs Comput. Mol. Sci. 2012, 2, 73-78.

S9. a) Becke, A. D. Density-functional thermochemistry. III. The role of exact exchange J. Chem. Phys. 1993, 98, 5648-5652; b) Lee, C. T.; Yang, W. T.; Parr, R. G. Development of the Colle-Salvetti correlation-energy formula into a functional of the electron density.Phys. Rev. B 1988, 37, 785-789.

S10. Weigend, F.; Ahlrichs, R. Balanced basis sets of split valence, triple zeta valence and quadruple zeta valence quality for H to Rn: Design and assessment of accuracy. Phys. Chem. Chem. Phys. 2005, 7, 3297-3305.

S11. Metz, B. Stoll, H.; Dolg, M. Small-core multiconfiguration-Dirac-Hartree-Fock-adjusted pseudopotentials for post-d main group elements: Application to $\mathrm{PbH}$ and $\mathrm{PbO}$, J. Chem. Phys. 2000, 113, 2563. ECP parameters for Sn have been obtained from the Turbomole basis set library at ftp://ftp.chemie.uni-karlsruhe.de/pub/basen/.

S12. Grimme, S.; Antony, J.; Ehrlich, S.; Krieg, H. A consistent and accurate ab initio parametrization of density functional dispersion correction (DFT-D) for the 94 elements H-Pu. J. Chem. Phys. 2010, 132, 154104.

S13. Bergner, A.; Dolg, M.; Kuchle, W.; Stoll, H.; Preuss, H. Ab initio energy-adjusted pseudopotentials for elements of groups 13-17. Mol. Phys. 1993, 80, 1431-1441.

S14. Riplinger, C.; Sandhoefer, B.; Hansen, A.; Neese, F. Natural triple excitations in local coupled cluster calculations with pair natural orbitals. J. Chem. Phys. 2013, 139, 134101.

S15. Pople, J. A.; Head-Gordon, M.; Raghavachari, K. "Quadratic configuration interaction. A general technique for

determining electron correlation energies" J. Chem. Phys., 1987, 87, 5968-5975.

S16. a) Neese, F.; Wennmohs, F.; Hansen, A. Efficient and accurate local approximations to coupled-electron pair

approaches: An attempt to revive the pair natural orbital method. J. Chem. Phys. 2009, 130, 114108; b) Neese, F.; Hansen,

A.; Wennmohs, F.; Grimme, S. Accurate theoretical chemistry with coupled pair models. Acc. Chem. Res. 2009, 42, 641648.

S17. Wennmohs, F.; Neese, F. A comparative study of single reference correlation methods of the coupled-pair type. Chem. Phys. 2008, 343, 217-230.

S18. Multiwfn 3.7. T. Lu, F. Chen, Multiwfn: A multifunctional wavefunction analyzer, J. Comput. Chem., 2012, 33, 580-592. Website http://sobereva.com/multiwfn/.

S19. a) Reed, A. E.; Weinhold, F. Natural bond orbital analysis of near-Hartree-Fock water dimer. J. Chem. Phys. 1983, 78, 4066-4073; b) Reed, A. E.; Weinstock, R.B.; Weinhold, F. Natural population analysis. J. Chem. Phys. 1985, 83, 735-746.

S20. Wiberg, K.B. Application of the Pople-Santry-Segal CNDO method to the cyclopropylcarbinyl and cyclobutyl cation and to bicyclobutane. Tetrahedron 1968, 24, 1083-1096.

S21. a) Mayer, I. Charge, bond order and valence in the AB initio SCF theory. Chem. Phys. Lett., 1983, 97, 270-274; b) Mayer, I. Bond order and valence: Relations to Mulliken's population analysis. Int. J. Quant. Chem. 1984, 26, 151-154; c) Mayer, I. Bond orders and valences in the SCF theory: A comment. Theor. Chim. Acta 1985, 67, 315-322; d) Mayer, I. Modelling of Structure and Properties of Molecules, Maksic, Z.B. Ed.; John Wiley \& sons: New York, NY, USA, 1987. e) Bridgeman, A.J.; Cavigliasso, G.; Ireland, L.R.; Rothery, J. The Mayer bond order as a tool in inorganic chemistry. J. Chem. Soc. Dalton Trans. 2001, 2095-2108.

S22. a) Bader, R.F.W. Atoms in Molecules: A Quantum Theory; Oxford University Press: Oxford, UK, 1990. b) Bader, R. F. W. A quantum theory of molecular structure and its applications. Chem. Rev. 1991, 91, 893-928; c) Matta, C. F.; Boyd, R. J. The Quantum Theory of Atoms in Molecules; Matta, C. F., Boyd, R. J., Eds.; Wiley-VCH: New York, NY, USA, 2007; pp. 134.

S23. Espinosa Ferao, A.; Streubel, R. Thiaphosphiranes and their complexes: Systematic study on ring strain and ring cleavage reactions. Inorg. Chem. 2016, 55, 9611-9619.

S24. a) Kyri, A.W.; Gleim, F.; García Alcaraz, A.; Schnakenburg, G.; Espinosa Ferao, A.; Streubel, R. 'Low-coordinate' 1,2oxaphosphetanes - a new opportunity in coordination and main group chemistry. Chem Commun. 2018, 54, 7123-7126; b)

Rey, A.; Espinosa Ferao, A.; Streubel, R. Quantum Chemical calculations on CHOP derivatives - spanning the chemical space of phosphinidenes, phosphaketenes, oxaphosphirenes and COP- isomers. Molecules, 2018, 23, 3341. 
S25. Espinosa Ferao, A. Kinetic energy density per electron as quick insight into ring strain energies. Tetrahedron Lett. 2016, 57, 5616-5619.

S26 a) Decius, J. C.; J. Chem. Phys., 1963, 38, 241-248; b) Jones, L. H.; Ryan, R. R. J. Chem. Phys., 1970, 52, 2003-2004; c) J. Baker, J. Chem. Phys., 2006, 125, 014103.

S27. a) Brandhorst, K.; Grunenberg. J. Chem.Soc. Rev., 2008, 37, 1558-1567. b) Büschel, S.; Jungton, A.-K.; Bannenberg, T.; Randoll, S.; Hrib, C. G.; Jones, P. G.; Tamm, M. Chem. Eur. J., 2009, 15, 2176-2184.

S28. a) G. von Frantzius, A. Espinosa Ferao, R. Streubel, "Coordination of CO to low-valent phosphorus centres and other related P-C bonding situations. A theoretical case study" Chem. Sci., 2013, 4, 4309-4322; b) Streubel, R.; Faßbender, J.; Schnakenburg, G.; Espinosa Ferao, A. "Formation of transient and stable 1,3-dipole complexes with P,S,C and S,P,C ligand skeletons" Organometallics, 2015, 34, 3103-3106; c) Espinosa Ferao, A.; Streubel, R. "Thiaphosphiranes and their complexes: systematic study on ring strain and ring cleavage reactions", Inorg. Chem., 2016, 55, 9611-9619.

S29. Stanford, M. W.; Schweizer, J. I.; Menche, M.; Nichol, G. S.; Holthausen, M. C.; Cowley, M. J., Intercepting the DisileneSilylsilylene Equilibrium. Angew. Chem. Int. Ed. 2019, 58, 1329-1333 and references cited therein. 